
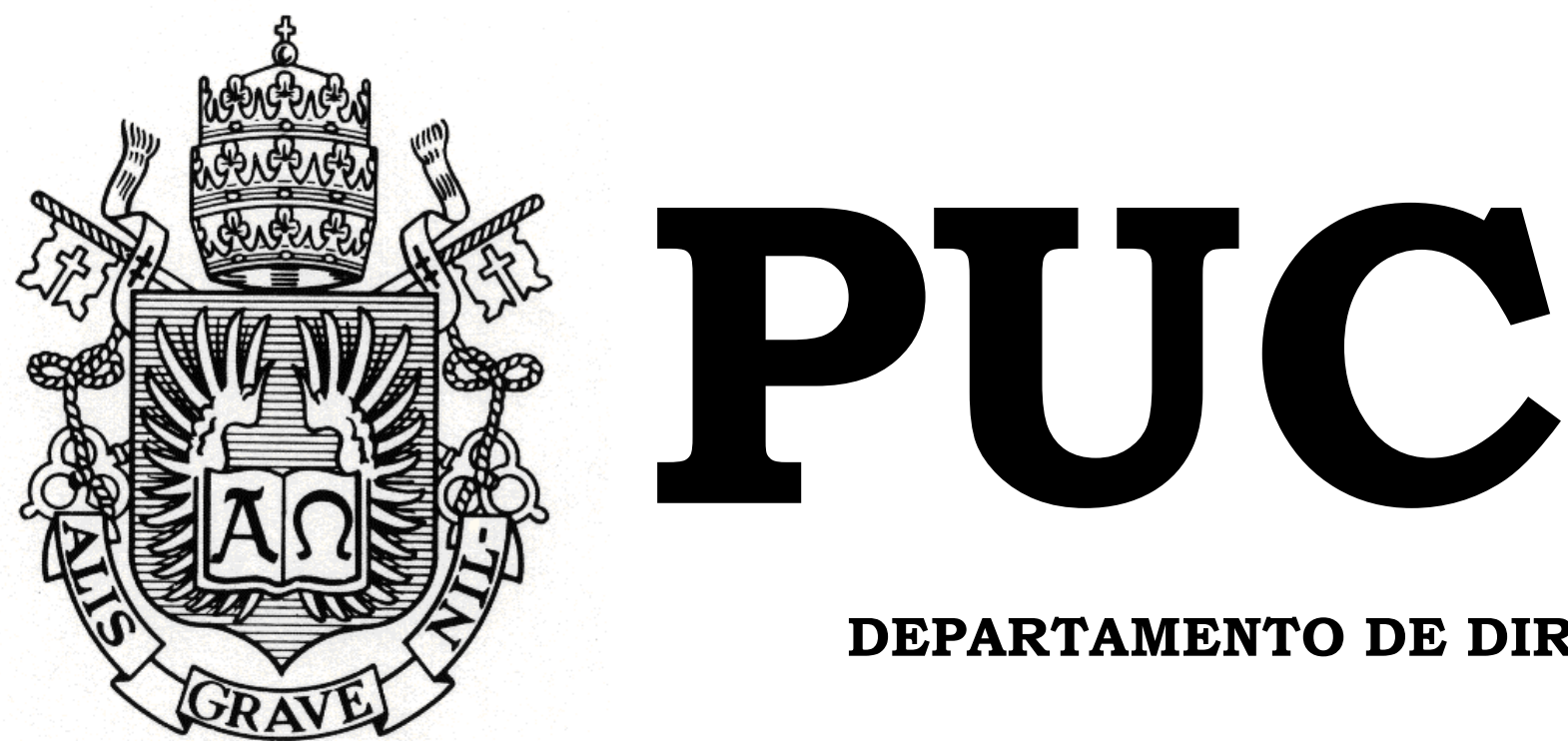

DEPARTAMENTO DE DIREITO

A Autorregulação das Bolsas de Valores e o Mecanismo de Ressarcimento de Prejuizos

por

Vinicius Saramago Tejerina de Araujo Sahione

ORIENTADORA: Norma Jonssen Parente

2012.2

PONTIFÍCIA UNIVERSIDADE CATÓLICA DO RIO DE JANEIRO

RUA MARQUÊS DE SÃO VICENTE, 225 - CEP 22453-900

RIO DE JANEIRO - BRASIL 


\title{
A AutorRegulação das Bolsas de VALORES E O MECANISMO DE Ressarcimento de Prejuízos
}

\author{
por \\ Vinicius Saramago Tejerina de Araujo Sahione
}

\begin{abstract}
Monografia apresentada ao Departamento de Direito da Pontificia Universidade Católica do Rio de Janeiro (PUC-Rio) para a obtenção do Título de Bacharel em Direito.
\end{abstract}

Orientadora: Norma Jonssen Parente 
Ao теи pai,

Carlos Eduardo Sahione, zelo e amor de pai, carinho de melhor amigo, incentivo e cobrança de mestre.

À minha mãe,

Simone Sahione, companheira fiel de todos os sorrisos, tristezas e circunstâncias.

Aos meus avós,

Clóvis e Valéria Sahione, que me criaram como se os primeiros fossem.

Aos amigos do Colégio Santo Inácio,

Que de alguma forma colaboraram em minha formação humana e me ensinaram o inestimável valor da amizade.

Aos colegas do SCBF,

Em particular aos amigos Eduardo Kuhlmann Abrantes e Carlos Augusto Junqueira, pelas sempre pontuais palavras de estímulo e a quem devo grande parte do conhecimento adquirido ao longo de minha formação profissional. 


\section{Resumo}

O presente trabalho final de curso, cujo objetivo importa na abordagem de questões do Direito Comercial, mais precisamente do regime jurídico do Mercado de Capitais, pretende, basicamente, expor de maneira analítica e sistemática a autorregulação do mercado de capitais brasileiro e o mecanismo de ressarcimento de prejuízos, este criado como forma de proteção ao investidor. Para tanto, procuraremos estruturar o corrente estudo em três partes, conforme resumidas adiante.

Primeiramente, abordaremos o contexto da criação da Comissão de Valores Mobiliários ("CVM"), o seu âmbito de competência e o seu atual papel regulatório e fiscalizador no âmbito do mercado de valores mobiliários pátrio. Posto isto, faz-se necessário delimitar o turvo âmbito de abrangência e de atuação das bolsas de valores, bem como o seu poder autorregulador perante seus jurisdicionados. Ainda nesse primeiro momento, analisaremos a autorregulação das bolsas de valores vis-à-vis a regulação - de competência originária - exercida pela CVM.

Ainda, trataremos da entidade por meio da qual a BM\&FBOVESPA S.A. - Bolsa de Valores, Mercadorias e Futuros de São Paulo ("BM\&FBOVESPA") atua na físcalização do mercado de valores mobiliários, a BM\&FBOVESPA Supervisão de Mercados - BSM, abordando a sua criação, principais atribuições e a composição de seus órgãos.

Em um segundo momento, debruçaremo-nos sobre o histórico do fundo de garantia das bolsas de valores, suas características originais e o ambiente econômico-regulatório no qual tal patrimônio de afetação foi 
instituído, analisando sua evolução até o sistema atualmente utilizado no Brasil, o Mecanismo de Ressarcimento de Prejuízos - MRP.

Mais a frente, e tal como foco da monografia, registraremos as principais hipóteses para o acionamento do mecanismo de ressarcimento de prejuízos pelo investidor, os anseios perquiridos pela Instrução da CVM n ${ }^{\circ}$ 461, de 23 de outubro de 2007, conforme alterada ("Instrução CVM 461"), bem como importantes reflexões acerca do contexto no qual tal mecanismo se insere, apontando o posicionamento da CVM quanto a determinados aspectos ali abordados. Ainda, apontaremos algumas fragilidades do Regulamento do Mecanismo de Ressarcimento de Prejuízos ("Regulamento do MRP" e "MRP", respectivamente).

Trata-se de um trabalho realizado com relativa dificuldade, uma vez que inexiste histórico de julgados consolidado e um rol consistente de doutrinadores que lecionam sobre o tema (principalmente sobre algumas particularidades do mecanismo de ressarcimento de prejuízos), somando-se ao fato de que grande parte dos artigos que tratam do assunto o fazem com indiscriminada - mas respeitável - superficialidade.

Não poupamos esforços, todavia, para expor discussões sobre a autorregulação do mercado de valores mobiliários brasileiro e as diversas faces, sob a mesma ótica, do mecanismo de ressarcimento de prejuízos. 


\section{ÍNDICE}

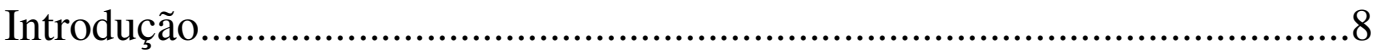

Capítulo 1. A Regulação do Mercado de Capitais Brasileiro..........................11

1.1. Breve Histórico da Regulação do Mercado de Capitais no Brasil......11

1.2. A CVM e o seu Papel Regulatório............................................................15

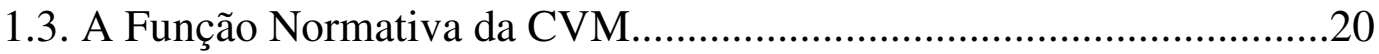

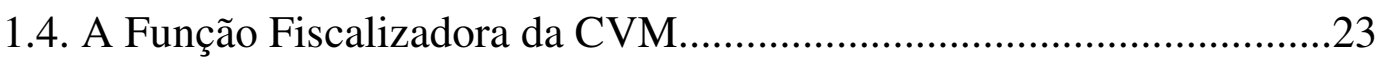

Capítulo 2. A Autorregulação no Mercado de Capitais Brasileiro...............27

2.1. Breve Histórico das Bolsas de Valores no Brasil...................................27

a) Processo de Integração das Bolsas de Valores................................32

b) Processo de Desmutualização das Bolsas de Valores...................34

2.2. A Autorregulação das Bolsas de Valores no Brasil................................37

Capítulo 3. A Autorregulação das Bolsas de Valores e a Regulação da CVM no Mercado de Capitais Brasileiro...............................................................4

Capítulo 4. A BM\&FBOVESPA Supervisão de Mercados - BSM..............51

4.1. A BSM como Entidade Autorreguladora e suas Atribuições.................51

4.2. A Administração da BSM..................................................................58

4.3. O Conselho de Supervisão da BSM......................................................64

Capítulo 5. Formas de proteção ao investidor e o atual "Mecanismo de Ressarcimento de Prejuízos - MRP”,

5.1. A Criação do "Fundo de Garantia das Bolsas de Valores" e suas

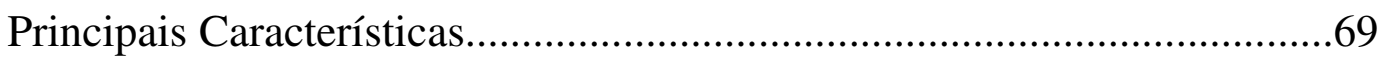

5.2. O MRP como nova modalidade de proteção ao investidor e a Instrução

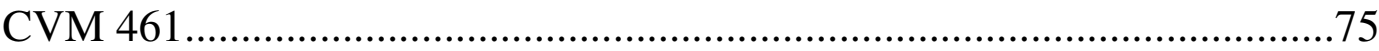

5.3. A Instrução CVM 461 e as Hipóteses de Acionamento do MRP..........81

a) Inadimplemento contratual e a (não) incidência do MRP.............83

b) Inexecução ou infiel execução de ordens........................................85 
c) Uso inadequado de numerário e de valores mobiliários ou outros ativos 88

d) Entrega ao investidor de valores mobiliários ou outros ativos ilegítimos ou de circulação restrita. 89

e) Inautenticidade de endosso em valores mobiliários ou outros ativos, ou ilegitimidade de procuração ou documento necessário à sua transferência

f) Intervenção ou decretação de liquidação extrajudicial pelo Banco

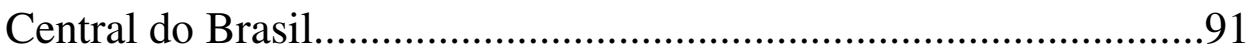

g) Encerramento das atividades........................................................92

5.4. As Características Primordiais do MRP mantido pela

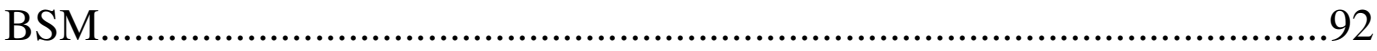

5.5. Algumas Reflexões sobre as peculiaridades do MRP.......................100

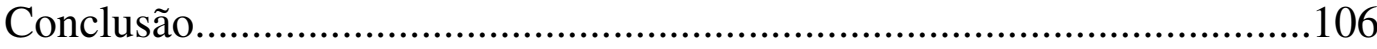

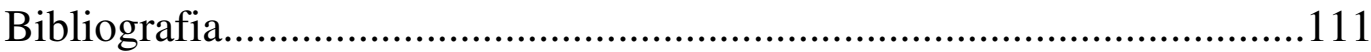




\section{Introdução}

Acredita-se que o surgimento dos primeiros estabelecimentos com características semelhantes ao que atualmente chamamos de "bolsas de valores" tenha ocorrido durante a Idade Média, por meio de transações com pedras e metais preciosos, moedas e letras de câmbio. Pode-se considerar que tais estabelecimentos, tidos por muitos como o embrião das bolsas de valores atuais, eram extremamente precários e sofriam com a ausência de liquidez financeira e de crédito.

Por outro lado, o termo "bolsa", em seu sentido técnico-comercial, nasceu na cidade de Bruges, na Bélgica. Na referida cidade, mais precisamente na casa de um senhor chamado Van der Burse, assembleias de comerciantes e banqueiros eram realizadas para a troca de produtos relativos aos seus negócios. ${ }^{1}$

Não obstante algumas divergências históricas, a constituição da primeira bolsa de valores do mundo, tal como conceituada modernamente, ocorreu apenas no início do século XVII, em Amsterdam, com a primeira emissão de ações e títulos de dívida pela Companhia Holandesa das Índias Orientais (há quem diga, outrossim, que a primeira bolsa de caráter internacional foi fundada em Antuérpia, no ano de $1531^{2}$ ).

No Brasil, considera-se que a concepção das bolsas de valores se deu no ano de 1877 , com o advento do Decreto $n^{\circ} 6.635$, o qual organizava a Corporação dos Corretores de Fundos Públicos e dispunha sobre as

\footnotetext{
${ }^{1}$ FILHO, Gustavo Alberto Villela. As Sociedades Corretoras e o Mercado de Valores Mobiliários. Rio de Janeiro: Lumen Juris, 2003. 65 p.

${ }^{2}$ MENDONÇA, José Xavier Carvalho de. Tratado de Direito Comercial Brasileiro. $3^{\circ}$ ed., vol. VI, parte II Rio de Janeiro, 1939, n. 1585. 280/281 p.
} 
operações a serem realizadas em bolsa ${ }^{3}$. A partir desse momento, a regulamentação evoluiu a passos lentos, até que a regulação do mercado de capitais brasileiro começou a tomar a forma que atualmente conhecemos, com o seu triunfo após a edição da Lei n ${ }^{\circ}$ 6.385, de 7 de dezembro de 1976, conforme alterada ("Lei da CVM"), que dispôs sobre o mercado de valores mobiliários e criou a Comissão de Valores Mobiliários.

Nesse momento podemos dizer que o mercado de capitais brasileiro iniciou o seu crescimento de maneira mais robusta e consistente, alcançando os atuais níveis de volume financeiro e quantidade de negócios (amplamente divulgados pela imprensa em geral), bem como uma maturidade jamais alcançada antes.

Tal como em todo crescimento acelerado, atrelado à forte rigidez econômica brasileira e ao amadurecimento da população quanto à necessidade da manutenção de uma poupança, algumas proteções aos investidores (e.g. o fundo de garantia das bolsas de valores, em 1966) foram sendo criadas e, gradativamente, aperfeiçoadas.

Em paralelo, e também a partir do advento da Lei da CVM, as bolsas de valores passaram a ter um caráter autorregulador, com funções tanto econômicas quanto regulatórias, o que notadamente contribuiu para o mencionado crescimento do mercado de capitais no Brasil, garantindo uma maior segurança e transparência aos investidores em geral, bem como elevados padrões éticos de negociação ${ }^{4}$.

Nesse caminho evolucionário, em conjunto com o boom dos investimentos por pessoas físicas no mercado de capitais, foi editada a

\footnotetext{
${ }^{3}$ MENDONÇA, José Xavier Carvalho de. Tratado de Direito Comercial Brasileiro. $3^{\circ}$ ed., vol. VI, parte II Rio de Janeiro, 1939, n. 1585. 67 p.

${ }^{4}$ EIZIRIK, Nelson et al.. Mercado de Capitais Regime Jurídico. $3^{\mathrm{a}}$ ed. Rio de Janeiro: Renovar, 2003. $210 \mathrm{p}$.
} 
Instrução CVM n ${ }^{\circ} 461$, de 23 de outubro de 2007, conforme alterada (“Instrução CVM 461"), que, dentre outros, disciplinou as regras para funcionamento e autorregulação das bolsas de valores, e a manutenção, por tais entidades, do MRP, o qual deveria possuir características semelhantes ao tacitamente extinto fundo de garantia das bolsas.

Em observância ao novo arcabouço regulatório que instituiu normativos sobre a autorregulação das bolsas de valores, a Bolsa de Valores de São Paulo, no mesmo ano de 2007 e no bojo de seu processo de desmutualização, optou por constituir a Bovespa Supervisão de Mercado BSM (hoje BM\&FBOVESPA - Supervisão de Mercados, ou “BSM”), entidade que desempenharia tais atividades de autorregulação.

Registra-se que a BSM, desde a sua criação, desempenha de maneira respeitosa e entusiasta suas funções, buscando pautar suas atividades à luz dos melhores padrões internacionais, atuando com transparência e zelo em todas as matérias que lhe competem, em especial a fiscalização, regulação e fortalecimento da integridade da BM\&FBOVESPA.

Com a eclosão da crise econômica mundial de 2008, ocasião que afetou adversamente tanto a bolsa de valores de São Paulo quanto a poupança dos pequenos investidores - que, em muitos casos, fora adquirida com sacrifício -, a importância da autorregulação no mercado de capitais e do MRP, cada um em suas respectivas esferas, se tornou latente, motivo que nos instigou a analisar cada um desses institutos de maneira profunda.

É no âmago dessa conjuntura jurídico-econômica que esperamos endereçar as qualidades, defeitos, fragilidades e pormenores do instituto do MRP e da atuação da BSM, como associação instituída para exercer a função autorreguladora da BM\&FBOVESPA - pautando-nos aqui, todavia e sempre que possível, pelo entendimento do agente regulatório originário 
do mercado de capitais, a CVM.

\section{Capítulo 1. A Regulação do Mercado de Capitais Brasileiro}

\subsection{Breve Histórico da Regulação do Mercado de Capitais no Brasil}

Pode-se considerar que a história do mercado de capitais no Brasil é recente, se comparada a outros países. Até o ano de 1964, os investimentos se restringiam exclusivamente a determinados bens (tais como imóveis), uma vez que os investimentos em títulos públicos e privados sofriam do chamado "risco Brasil", assombrados pelo risco de moratória do Governo, pela instabilidade política, por uma moeda inexpressiva e pelo "fantasma" da inflação. Nesse particular, o Sistema Financeiro Nacional se baseava em leis ultrapassadas e confusas, o que gerava um desconforto estridente para os investidores nacionais e estrangeiros.

As funções do atual Banco Central do Brasil ("BCB"), até a sua criação pela Lei de Reforma do Sistema Financeiro Nacional (conforme abaixo definida), eram realizadas conjuntamente pela Superintendência da Moeda e do Crédito - SUMOC, pelo Banco do Brasil e pelo Tesouro Nacional. Nesse sentido, a SUMOC tinha, dentre outras, a finalidade de exercer o controle monetário e preparar a organização de um banco central. Já o Banco do Brasil tinha, também dentre outras, a finalidade de desempenhar as funções de banco do governo. Por último, o Tesouro Nacional era o órgão emissor de papel-moeda do Governo ${ }^{5}$.

Com o advento de importantes diplomas legais, como a Lei $\mathrm{n}^{\circ} 4.728$, de 14 de julho de 1965, conforme alterada ("Lei de Mercado de Capitais"),

\footnotetext{
${ }^{5}$ Fonte: http://www.bcb.gov.br/?HISTORIABC.
} 
a Lei da CVM, a Lei ${ }^{\circ} 4.595$, de 31 de dezembro de 1964, conforme alterada ("Lei de Reforma do Sistema Financeiro Nacional") e a Lei ${ }^{\circ}$ 6.404, de 15 de dezembro de 1976, conforme alterada ("Lei das Sociedades por Ações"), iniciou-se um processo de reordenamento no Sistema Financeiro Nacional de forma a tentar suprir a carência de uma estruturação racional que se adequasse aos anseios da sociedade brasileira em geral.

Cumpre ressaltar que a atividade de regulação e fiscalização do mercado de capitais brasileiro, desde a Lei de Reforma do Sistema Financeiro Nacional até a entrada em vigor da Lei da CVM, era integralmente exercida pelo Banco Central do Brasil, conjuntamente com o Conselho Monetário Nacional, o que teria sido extremamente criticado à época na medida em que referidas entidades não possuíam meios para absorver todos os problemas ou anseios eventualmente surgidos do complexo sistema do mercado de capitais.

Com efeito, a própria exposição de motivos da Lei da CVM já dava sinais de que a criação de uma entidade especializada era imperiosa para que não houvesse abusos ou distorções no mercado de capitais em geral, senão vejamos:

“3. O projeto de lei das sociedades por ações pressupõe a existência de novo órgão federal - a Comissão de Valores Mobiliários - com poderes para disciplinar e fiscalizar o mercado de valores mobiliários e as companhias abertas.

4. A experiência demonstrou que a defesa da economia popular e o funcionamento regular do mercado de capitais exigem a tutela do Estado, com a fixação de normas para emissão de títulos destinados ao público, divulgação de dados sobre a companhia emitente e negociação dos títulos no mercado. Além disso, é necessário que agência governamental especializada exerça as funções de polícia do mercado, evitando as distorções e abusos a que está sujeito." 
$\mathrm{Na}$ mesma exposição de motivos, e mais adiante, resta patente o deficitário exercício do Banco Central do Brasil e do Conselho Monetário Nacional em suas atribuições quanto à regulação do mercado de capitais pátrio, a saber:

“5. A Lei n. ${ }^{\circ}$ 4.728, de 1965, organizou o mercado de capitais, sob a disciplina do Conselho Monetário Nacional e a fiscalização do Banco Central do Brasil. 0 legislador da época entendeu que o mercado de capitais, então incipiente, não justificava a criação de órgão especializado para fiscalizar. O Banco Central, que estava sendo instalado, era o órgão naturalmente indicado para exercer a função. Entretanto, o Banco Central, cuja função precípua é a de gestor da moeda, do crédito, da dívida pública e do balanço de pagamentos, e não deve ter as suas atribuições sobrecarregadas com a fiscalização do mercado de valores mobiliários.”

Diante disso, a Lei da CVM entrou em vigor instituindo uma nova ordem para o mercado de capitais vigente, na qual uma entidade fiscalizadora seria criada, destinada exclusivamente à regulamentação e ao desenvolvimento do mercado de capitais em geral e à fiscalização das bolsas de valores e das companhias abertas. Tal entidade, quando da sua instalação no ano de 1978, teria como entes regulados um total de 2.224 entidades $^{6}$, o que, para época, e apesar da relativa complexidade do mercado de valores mobiliários brasileiro, já era um número considerável. Por sua vez, o Banco Central do Brasil se restringiria à disciplina do sistema financeiro bancário, monetário e creditício.

\footnotetext{
${ }^{6}$ Como observa Valdir de Jesus, o número de entidades sujeitas à regulação e fiscalização da CVM, no ano de 2001, ultrapassava 6.000 instituições (LAMEIRA, Valdir de Jesus. Mercado de Capitais. $1^{\mathrm{a}}$ ed. Rio de Janeiro: Forense Universitária, 2001. 123.p)
} 
Nas palavras do jurista Nelson Eizirik ${ }^{7}$, "a estrutura do mercado financeiro lato sensu passou do modelo bipartido da Lei $n^{\circ}$ 4.728/1965 para o modelo tripartido da Lei $n^{\circ}$ 6.385/1976, com clara distinção entre os objetos, de um lado, do mercado financeiro stricto sensu e, de outro, do mercado de capitais".

Tal modelo bipartido a que o renomado jurista faz menção baseavase, como já mencionado acima, no Banco Central do Brasil e no Conselho Monetário Nacional como órgãos máximos do mercado financeiro "lato sensu" (i.e., o mercado financeiro como figura composta tanto por operações financeiras quanto pelo mercado de valores mobiliários em geral). Já o modelo tripartido tinha como característica principal o exercício de uma atividade supervisora-pendular pelo Conselho Monetário Nacional, já que o mesmo permanecia isolado como órgão máximo do Sistema Financeiro Nacional, direcionando as políticas do Banco Central do Brasil e da CVM conforme suas atribuições quanto ao mercado financeiro e de valores mobiliários, respectivamente.

O processo de independência da CVM somente começou a ser traçado 20 anos após a promulgação da Lei da CVM, com a edição da Lei $\mathrm{n}^{\circ}$ 9.457, de 5 de maio de 1997 (“Lei n 9.457”). Tal diploma legal, por sua vez, aumentou o poder de polícia da CVM (até então, por vezes, ineficaz), uma vez que aumentou o grau de severidade e o rol das sanções originalmente previstas na Lei da CVM.

Apenas cinco anos depois, com edição da Medida Provisória $n^{\circ} 8$, posteriormente convertida na Lei ${ }^{\circ} 10.411$, de 26 de fevereiro de 2002, a CVM passou definitivamente a gozar do status de "entidade autárquica em regime especial", isto é, de agência reguladora do mercado de capitais no

${ }^{7}$ EIZIRIK, Nelson et al.. Mercado de Capitais Regime Jurídico. $2^{\mathrm{a}}$ ed. Rio de Janeiro: Renovar, 2008. 260 p. 
Brasil, característica que, como veremos mais a frente, teria sido de enorme importância para o desenvolvimento e transparência do mercado de valores mobiliários na última década.

\subsection{A CVM e o seu Papel Regulatório}

Antes de adentrarmos no papel regulatório da CVM, nos permitimos analisar, brevemente, o conceito de agência reguladora diante da legislação brasileira, acentuando-se, de início, que a sua criação propugna o processo de despolitização das decisões do Estado, dotadas de um caráter eminentemente político, priorizando um conteúdo técnico e visando a afastar a interferência partidária e burocrática, além de atender à pluralidade de interesses, com regulações específicas, setorizadas e independentes ${ }^{8}$.

Como é sabido, o conceito de agência reguladora no Brasil tem como inspiração o conceito de "agency" do direito administrativo norteamericano, segundo o qual as "agencies" seriam organismos autônomos e independentes relativamente ao modelo estatal tripartite. $\mathrm{O}$ ideal perquirido na conjuntura política que criou as "agencies" era o de prover ao Estado entidades especializadas que possuíssem, à igual medida, especialidade, conhecimento técnico e agilidade para o direcionamento de diversos setores da atividade econômica.

Mais precisamente no âmbito do direito administrativo brasileiro, e nas palavras do renomado jurista Celso Antonio Bandeira de Mello, “as agências reguladoras são autarquias sob regime especial, ultimamente criadas com a finalidade de disciplinar e controlar certas atividades"”. $\mathrm{O}$

\footnotetext{
${ }^{8}$ Fonte: Parecer/CVM/PJU/N 001/2003, elaborado em 6 de fevereiro de 2003 pelo ProcuradorChefe da CVM, Ilmo. Dr. Henrique de Rezende Vergara.

${ }^{9}$ MELLO, Celso Antonio Bandeira de. Curso de Direito Administrativo. $17^{\mathrm{a}}$ ed. São Paulo: Malheiros Editores, 2004. 157p.
} 
mesmo autor, mais a frente ${ }^{10}$, se refere à CVM como uma autarquia "de índole equivalente às das "agências reguladoras” e à qual também veio a ser atribuído o qualificativo de autarquia "sob regime especial”, mas que não recebeu a designação de "agência", pois foi mantido seu nome original: Comissão de Valores Mobiliários - CVM'.

De forma mais incisiva elucidou a Ilma. Diretora da CVM, Sra. Norma Jonssen Parente $^{11}$, ao expressar as finalidades das agências reguladoras, senão vejamos:

\begin{abstract}
"Essas entidades são especializadas e estruturadas com uma maior independência, a fim de enfrentar os conflitos apostos pelas atuais sociedades, cada vez mais plurais e complexas, com mais rapidez, sem a interferência de fatores atécnicos, com menos rigidez e sem excluir a participação dos regulados. Assim essas entidades alcançam mais facilmente a consolidação do princípio da eficiência administrativa."
\end{abstract}

Pode-se dizer, em suma, que o conceito de agência reguladora no Brasil foi quase que em sua totalidade importado do conceito de "agency" norte-americano, tendo sido apenas "abrasileirado" em alguns pontos de forma compatibilizá-lo ao regime constitucional pátrio.

Não é por outro motivo que a CVM - agência reguladora do mercado de valores mobiliários, ainda que sem denominação específica de agência - possui atualmente um papel regulatório de inegável relevância no mercado de capitais brasileiro, tendo como sua principal missão a regulação, fiscalização, normatização e o controle das atividades realizadas pelos entes a ela subordinados, em estrita atenção ao interesse público.

\footnotetext{
${ }^{10}$ Ibid. 158 p,

11 Voto proferido, em 21 de setembro de 2004, no âmbito do Processo CVM n ${ }^{\circ}$ RJ 2004/45584559-4569-4583.
} 
Nesse sentido, a CVM, criada à imagem e semelhança de seu par nos Estados Unidos, a Securities and Exchange Commission, por meio da Lei da CVM, deverá exercer as seguintes funções ${ }^{12}$ :

(i) estimular a formação de poupanças e a sua aplicação em valores mobiliários;

(ii) promover a expansão e o funcionamento eficiente e regular do mercado de ações, e estimular as aplicações permanentes em ações do capital social de companhias abertas sob controle de capitais privados nacionais;

(iii) assegurar o funcionamento eficiente e regular dos mercados da bolsa e de balcão;

(iv) proteger os titulares de valores mobiliários e os investidores do mercado contra: (a) emissões irregulares de valores mobiliários; (b) atos ilegais de administradores e acionistas controladores das companhias abertas, ou de administradores de carteira de valores mobiliários; e (c) o uso de informação relevante não divulgada no mercado de valores mobiliários;

(v) evitar ou coibir modalidades de fraude ou manipulação destinadas a criar condições artificiais de demanda, oferta ou preço dos valores mobiliários negociados no mercado;

(vi) assegurar o acesso do público a informações sobre os valores mobiliários negociados e as companhias que os tenham emitido;

\footnotetext{
${ }^{12}$ Fonte: Artigo $4^{\circ}$ e incisos da Lei da CVM.
} 
(vii) assegurar a observância de práticas comerciais equitativas no mercado de valores mobiliários; e

(viii) assegurar a observância no mercado, das condições de utilização de crédito fixadas pelo Conselho Monetário Nacional.

Primeiramente, podemos dizer que o referido mister consiste no exercício da atividade de edição de normas de conduta para os participantes do mercado de capitais, além da fiscalização dos mesmos quanto ao cumprimento das diretrizes impostas pela CVM, aplicando sanções ou advertências em casos de descumprimento.

Mais do que isso, a CVM tem como função a limitação de atos potencialmente nocivos acometidos pelos participantes do mercado, de tal modo que deformações ou danos em geral, tal como ocorrem em outros mercados considerados mais "liberais", não ocorram com certa habitualidade.

Para tanto, referida autarquia se limita ao conceito de valores mobiliários (mercado que lhe compete fiscalizar) e dos contratos ou operações os envolvendo. Insta mencionar que o rol de valores mobiliários ampliou-se em uma primeira ocasião, com a Lei $n^{\circ} 9.457$, e por duas outras vezes, com as Leis de $\mathrm{n}^{\circ} 10.198$ e 10.303, ambas de 2001.

Além do conceito de valores mobiliários, deve a CVM, outrossim, pautar-se pela supervisão dos entes participantes do mercado de capitais no que concerne à correta execução e aplicação, pelos mesmos, do princípio do "full and fair disclosure", ou da divulgação completa de informação. Não é 
por outro motivo que o artigo $4^{\circ}$, inciso VI, da Lei da CVM, conforme disposto acima, dispõe de maneira cristalina que a CVM deverá exercer suas funções com o fim de assegurar o acesso do público a informações sobre os valores mobiliários negociados e as companhias que os tenham emitido. Tal princípio do "full and fair disclosure" tem como horizonte a proteção tanto dos titulares de valores mobiliários quanto dos investidores em geral contra atos ilegais de administradores e controladores de companhias abertas, bem como asseverar a observância de práticas equitativas.

Nesse particular, frisamos que a CVM não deve - e nem poderia - se restringir puramente à realização de atividades de cunho normativo, fiscalizador ou regulatório; mas também abarcar atividades de caráter preventivo, uma vez que a última vem se revelando, comparativamente, cada vez mais eficaz no desenvolvimento do mercado de valores mobiliários do que as anteriores.

Com relação à competência da CVM, o artigo $1^{\circ}$ da Lei da CVM dispõe que a mencionada entidade deverá fiscalizar, supervisionar e disciplinar as seguintes atividades: (i) a emissão, distribuição, negociação e intermediação no mercado de valores mobiliários e de derivativos; (ii) a organização, o funcionamento e as operações das Bolsas de Valores e das de Mercadorias e Futuros; (iii) a administração de carteiras e a custódia de valores mobiliários; (iv) a auditoria das companhias abertas; e (v) os serviços de consultor e analista de valores mobiliários. Destaca-se, ainda, o forçoso papel da CVM em fiscalizar e inspecionar as companhias abertas.

A Lei da CVM ainda traz importantes medidas como forma de prevenção ou correção, pela mesma autarquia, de situações anormais de mercado, a saber: (i) suspender a negociação de determinado valor mobiliário ou decretar o recesso de bolsa de valores; (ii) suspender ou 
cancelar os registros de que trata a mencionada lei; (iii) divulgar informações ou recomendações com o fim de esclarecer ou orientar os participantes do mercado; e (iv) proibir aos participantes do mercado, sob cominação de multa, a prática de atos que especificar, prejudiciais ao seu funcionamento regular.",13

\subsection{A Função Normativa da CVM}

Pode-se considerar que, no universo das funções das agências reguladoras, a função normativa já foi a mais criticada pela doutrina em geral, na medida em que representaria verdadeira invasão da esfera do poder originalmente competente para criar leis e normas: o Poder Legislativo. Entendemos, todavia, que tal discussão restaria - pelo menos por enquanto - superada, tendo em vista grande parte da atual doutrina entender a produção de regras técnicas acerca do desempenho de atividades econômicas relevantes como sendo de titularidade das respectivas agências reguladoras responsáveis pela fiscalização de tais atividades (teoria, inclusive, da qual nos filiamos).

Assim, podemos dizer que a competência das agências reguladoras não reside apenas na execução da lei que a instituiu, mas sim de regular, com patente rapidez, eficiência, e, sobretudo, sem interferência política, as matérias a que se submeteu fiscalizar.

Com efeito, e nos atendo ao poder regulatório da CVM, a prestação de informações por todos os participantes do mercado de valores mobiliários pode ser considerada o maior bem jurídico a ser tutelado pelo Estado no âmbito do mercado de capitais. Esse standard (i.e., a divulgação de informações) deve ser cuidadosamente fiscalizado e, principalmente,

\footnotetext{
${ }^{13}$ Fonte: Artigo $9^{\circ}, \S 1^{\circ}$, da Lei da CVM.
} 
delimitado pela CVM por meio da edição de normas de cunho elucidativo e orientador, sempre à luz do que dispõe a Lei das Sociedades por Ações. Nesse sentido, requer a indigitada Autarquia que as companhias abertas e os participantes do mercado em geral (tais como fundos de investimento, clubes de investimento, dentre outros) divulguem periodicamente diversas informações, de modo a munir os investidores das informações necessárias para a decisão de seus investimentos.

Podemos dizer que a base legal que outorga o poder regulamentar da CVM encontra-se na própria Lei da CVM, em seu artigo $8^{\circ}$, inciso $1^{\circ}$, ao estipular que competirá à CVM "regulamentar, com observância da política definida pelo Conselho Monetário Nacional, as matérias expressamente previstas nesta Lei e na lei de sociedades por ações".

Como já dito, a tutela da CVM quanto à obrigação de seus jurisdicionados na prestação de informações se dá por meio de ações de cunho normativo e regulamentar, as quais podem se dividir, conforme a Deliberação da CVM n ${ }^{\circ}$ 1, de 23 de fevereiro de 1978, da seguinte maneira:

Instruções: normas específicas por meio das quais a CVM regulamenta matérias expressamente previstas na Lei das Sociedades por Ações e na Lei da CVM.

Deliberações: possuem o intuito de consubstanciar todos os atos do Colegiado que constituam competência específica do mesmo nos termos do Regimento Interno da CVM..

Pareceres: constituem respostas às consultas formuladas por agentes de mercado, investidores ou pela própria CVM, a respeito de matérias reguladas por tal autarquia. 
Pareceres de Orientação: representam o entendimento da CVM sobre matéria que lhe caiba regular. Os Pareceres de Orientação servirão, também, para veicular as opiniões da CVM sobre interpretação da Lei da CVM e da Lei das Sociedades por Ações no interesse do mercado de capitais.

Notas Explicativas: tornam públicos os motivos que levaram a CVM a baixar norma ou apresentar proposição ao CMN, além de fornecer explicações sobre a utilização da norma.

Portarias: compreende atos que envolvam aspectos da administração interna da CVM.

Atos Declaratórios: documento pelo qual a CVM credencia ou autoriza o exercício de atividades no mercado de valores mobiliários.

Por fim, e não obstante estar a CVM, indubitavelmente, sujeita ao princípio da legalidade, não podemos deixar de ressaltar que o exercício de suas atividades não pode - e nem deve - ser comparado ao de outras entidades autárquicas cujo espectro de atuação pode ser considerado mais engessado (i.e., sem a capacidade de inovar a lei), uma vez (i) o objeto da matéria que the compete estar sempre em plena transformação; e (ii) a entrada e saída dos agentes privados ao mercado ter um caráter extremamente dinâmico e requerer uma atuação mais firme e que atenda aos anseios do mercado, sob pena de graves danos à economia em geral. 


\subsection{A Função Fiscalizadora da CVM}

Uma vez considerada a CVM uma "entidade autárquica em regime especial", ou, como já vimos falando, uma "agência reguladora", não podemos deixar de mencionar o seu poder de polícia, com um viés sancionador, no que tange ao mercado de valores mobiliários, cujos poderes abrangem desde a contenção dos agentes de mercado até a punição dos mesmos em caso de condutas consideradas danosas ao mercado.

Com efeito, pode-se dizer que a CVM, imbuída de seu poder fiscalizador, atua na limitação das liberdades individuais vis-à-vis o interesse público ou coletivo ${ }^{14}$, de forma a assegurar o funcionamento eficiente e regular do mercado de capitais. Indo mais além, insta salientar que a CVM tem o poder-dever de intervir, investigar e eventualmente punir quaisquer atos que venham a ser nocivos à transparência e à lisura do mercado de valores mobiliários pátrio.

Cabe mencionar, entretanto, que o poder de polícia da CVM esbarra na noção da "obediência à ordem jurídica constituída pela Constituição Federal", sendo certo que tal poder jamais poderia ser exercido de maneira arbitrária ou discricionária; mas sim observando determinados princípios inerentes à Administração Pública.

Seguindo no âmbito da função fiscalizadora da CVM, o artigo $9^{\circ}$ da Lei da CVM, bem como seus parágrafos, sem prejuízo de outros dispositivos previstos na regulamentação aplicável, dispõe que a autarquia poderá realizar, no âmbito do seu mister fiscalizador, os seguintes atos:

\footnotetext{
${ }^{14}$ DI PIETRO, Maria Sylvia Zanella. Direito Administrativo. São Paulo: Atlas, 2001. 110p.
} 
(i) examinar os registros contábeis, livros e documentos de, dentre outros, companhias abertas e demais emissoras de valores mobiliários, auditores independentes, fundos de investimento e consultores e analistas de valores mobiliários;

(ii) intimar pessoas para prestação de informações ou esclarecimentos;

(iii) requisitar informações de qualquer órgão público, autarquia ou empresa pública;

(iv) determinar às companhias abertas a republicação, com correções ou aditamentos, das demonstrações financeiras, relatórios e outras informações divulgadas;

(v) apurar, mediante processo administrativo, atos ilegais e práticas não equitativas de administradores, membros do conselho fiscal e acionistas de companhias abertas, dos intermediários e dos demais participantes do mercado;

(vi) suspender a negociação de valores mobiliários;

(vii) suspender ou cancelar registros; e

(viii) proibir aos participantes do mercado a prática de atos que especificar, prejudiciais ao seu funcionamento regular.

Ademais, e após constada irregularidades praticadas por determinado participante do mercado em processo administrativo específico, a CVM poderá cominar, com o fim de inibir práticas nocivas reiteradas por outros participantes, as seguintes penalidades: 
(i) advertência;

(ii) multa;

(iii) suspensão do exercício do cargo de administrador ou de conselheiro fiscal de companhia aberta, de entidade do sistema de distribuição ou de outras entidades que dependam de autorização ou registro na CVM;

(iv) inabilitação temporária, até o máximo de 20 anos, para o exercício dos cargos referidos no inciso anterior;

(v) suspensão da autorização ou registro para o exercício das atividades de que trata a Lei da CVM;

(vi) cassação da autorização ou registro para o exercício das atividades de que trata a Lei da CVM;

(vii) proibição temporária, até o máximo de 20 anos, de praticar determinadas atividades ou operações, para os integrantes do sistema de distribuição ou de outras entidades que dependam de autorização ou registro na CVM; e

(viii) proibição temporária, até o máximo de 10 anos, de atuar, direta ou indiretamente, em uma ou mais modalidades de operação no mercado de valores mobiliários. 


\section{Capítulo 2. A Autorregulação no Mercado de Capitais Brasileiro}

\subsection{Breve Histórico das Bolsas de Valores no Brasil}

A criação das bolsas de valores no Brasil está intimamente ligada ao modelo de desenvolvimento econômico adotado historicamente pelo governo brasileiro, baseado precipuamente na manutenção de dois tipos de instituições: os bancos comerciais e as bolsas de valores.

Primeiramente, cumpre ressaltar que, até o início do século XIX, não era possível encontrar no Brasil instituições financeiras especializadas nos diversos tipos de crédito disponíveis atualmente, mas tão somente entes do setor privado (mais precisamente indivíduos) que exerciam voluntariamente as funções de uma instituição financeira ou de uma sociedade corretora, cenário que começou a ser alterado apenas na segunda metade do século $\mathrm{XX}$, com o surgimento de entidades especializadas em ramos creditícios distintos.

Somente com o advento do Decreto ${ }^{\circ} 417$, de 14 de junho de 1845 , conforme alterado ("Decreto 417"), que previa a arrecadação de impostos sobre os corretores, o ofício dos agentes intermediários foi devidamente regulado. O objetivo do Decreto 417, como poderá ser observado abaixo, era limitar o número amplo de pessoas que, até então, prestavam serviços de intermediação, além de instituir um "dízimo" - já que não podemos nos permitir chamar a taxa então instituída de "imposto", tendo em vista sua abominável simplicidade - sobre as operações realizadas.

Para tanto, o Decreto 417, em seu artigo $3^{\circ}$, instituiu que "para ser Corretor qualquer individuo, é preciso que seja maior de vinte e cinco 
annos, que tenha praticado o commercio por tres annos, pelo menos, em alguma casa mercantil, ou de Corretor de qualquer das Praças do Imperio, não podendo sel-o os Ecclesiasticos, Militares, Funccionarios Publicos, os Negociantes quebrados e não rehabilitados, e os Corretores uma vez demitidos (...)".

A atual Rua Primeiro de Março, antes "Rua Direita", situada no Rio de Janeiro, era o ponto de encontro dos corretores, já que presidia, na época, a Alfândega e o Paço Imperial, conclaves políticos e comerciais do maior porto exportador do País. Com um local, "informalmente fixo", para a realização de reuniões espontâneas que objetivavam a efetivação de transações comerciais por compradores e vendedores, iniciou-se um processo de convergência nacional dos comerciantes e produtores de todos os estados do Brasil naquele logradouro, eclodindo invariavelmente em um sistema de liquidez mais eficiente para a época.

Com o crescente interesse do Estado na organização dos corretores (já que o fomento dessa atividade ocasionaria em uma maior arrecadação de impostos), instituiu-se, por meio do Decreto $\mathrm{n}^{\circ}$ 6.132, de 4 de março de 1876, conforme alterado (“Decreto 6.132”), a cotação oficial dos fundos públicos, ações de companhias, metais preciosos e a verificação do curso dos câmbios e descontos, considerado marco regulatório das bolsas de valores, e, no ano seguinte, por meio do Decreto $\mathrm{n}^{\circ}$ 6.635, de 26 de julho e "atendendo ao que representou a Junta dos Corretores da Praça do Rio de Janeiro", passou a dar condições para realização dos negócios no Rio de Janeiro.

Instituiu-se nesse período, no edifício da Associação Comercial, à Rua Direita, a "Bolsa de Fundos Públicos do Rio de Janeiro", local onde a entrada era unicamente permitida aos corretores e onde seriam realizadas 
todas as operações de fundos públicos ${ }^{15}$.

Vinte anos mais tarde, mais precisamente em 13 de março de 1897, foi expedido o que veio a se considerar um importante momento da legislação brasileira sobre as bolsas de valores: o Decreto $\mathrm{n}^{\circ} 2.475$. Não obstante seu caráter relativamente elaborado para a época, o mencionado diploma legal concentrava-se apenas em regular as atividades da bolsa de valores e dos corretores da "capital federal", omitindo-se, portanto, quanto ao exercício de tais atividades em outros estados do País.

Com efeito, a legislação brasileira, até o advento do Decreto $n^{\circ}$ 2.475, dava sinais de que se encontrava desgastada e de que necessitava de novos diplomas legais. Posto isto, a criação do Decreto $\mathrm{n}^{\circ} 2.475$, além de regular as atividades bursáteis e de corretagem, segregou o escopo deste ofício, passando os corretores de mercadorias e navios a ter sua regulamentação própria, sua "Junta" e seus locais de negociação em separado.

Nesse sentido, instituiu-se que a bolsa de valores seria o lugar “destinado ás operações de compra e venda de títulos públicos, de ações de bancos e companhias, de valores comerciais e de metais preciosos"16, restando apenas aos corretores de fundos a permissão para "acesso dentro da balaustrada da Bolsa"17.

O exercício das atividades das bolsas de valores em âmbito nacional, com exceção do Rio de Janeiro e de São Paulo (esta criada por meio de ato

\footnotetext{
${ }^{15}$ Como bem assevera o autor Gustavo Alberto Villela Filho, pôde se verificar, um ano após a entrada em vigor do Decreto $\mathrm{n}^{\circ}$ 6.635, um aumento de $530 \%$ nas transações e mais de $100 \%$ no número de companhias com títulos naquela instituição. FILHO, Gustavo Alberto Villela. As Sociedades Corretoras e o Mercado de Valores Mobiliários. Rio de Janeiro: Lumen Juris, 2003. $67 \mathrm{p}$.

${ }^{16}$ Fonte: Artigo 76 do Decreto ${ }^{\circ} 2.475$, de 13 de março de 1897.

${ }^{17}$ Fonte: Artigo 77 do Decreto ${ }^{\circ} 2.475$, de 13 de março de 1897, conforme alterado.
} 
do governo estadual em 1895), somente teria sido inicialmente regulamentada por meio do Decreto ${ }^{\circ}$ 24.275, de 1934.

Em 13 de junho de 1939, com o advento do Decreto-Lei $\mathrm{n}^{\circ}$ 1.344, conforme alterado ("Decreto-Lei 1.344"), estabeleceu-se uma legislação mais afirmativa e integrada para todas as operações realizadas em bolsas de valores do País, não mais havendo qualquer distinção regulatória entre bolsas de determinados estados, tal como até então. As bolsas de valores permaneceriam, todavia, como entidades eminentemente públicas, com intervenção corriqueira dos governos estaduais em suas administrações (vinculadas às secretarias de finanças), autorizadas a suportar, segundo o artigo 15 do Decreto-Lei 1.344, operações (i) à vista; (ii) a termo; e (iii) de câmbio, bem como com títulos da mais distinta natureza, isto é, (a) títulos federais; (b) títulos estaduais; (c) títulos municipais; (d) ações; (e) debêntures; e (f) outros valores.

Pode-se dizer que com o estabelecimento desse novo arcabouço regulatório, deflagrou-se um processo definitivo tanto de "constituição" de novas bolsas de valores estaduais quanto da conversão das já existentes bolsas de fundos públicos em bolsas de valores propriamente ditas, estas inspiradas no modelo norte-americano.

É possível afirmar que a constituição e o amadurecimento dos mercados de bolsa no Brasil se deram, especialmente, em conjunto com o latente desenvolvimento estrutural do sistema financeiro nacional.

A partir do ano de 1964, com as transformações políticas representadas pela queda do presidente João Goulart e o advento do golpe militar, um novo período de reformas legislativas é instaurado, principalmente porque a "convicção da necessidade de reformas 
institucionais acompanhou o PAEG ${ }^{18}$ desde seu diagnóstico. Três áreas foram particularmente destacadas, refletindo, acertadamente, a percepção do governo a respeito dos pontos de estrangulamento institucionais da economia: primeiro, a desordem tributária; segundo, as deficiências de um sistema financeiro subdesenvolvido e a inexistência de um mercado de capitais; e, por último, as ineficiências e as restrições ligadas ao comércio exterior $" 19$.

Diversos fatores levaram à evolução do status das bolsas de valores para o que observamos hoje em dia, tais como a criação da Lei da CVM, a Lei de Mercado de Capitais, a Lei de Reforma do Sistema Financeiro Nacional e a Lei das Sociedades por Ações. Soma-se a isso o advento da Resolução do Conselho Monetário Nacional n 39, de 20 de outubro de 1966, conforme alterada ("Resolução CMN 39"), que alterou, por meio de seu artigo $1^{\circ}$, a natureza jurídica das bolsas de valores para "associações civis, sem finalidades lucrativas", e instituiu o regulamento que disciplinava a constituição, organização e o funcionamento das bolsas de valores. Ainda de acordo com a Resolução CMN 39, tais bolsas de valores seriam compostas pelas sociedades corretoras e funcionariam sob a supervisão do Banco Central do Brasil, passando a funcionar conforme tal modelo de organização institucional.

No início da década de 1970, as bolsas de valores, visando à majoração do volume de seus negócios e, consequentemente, de seus resultados financeiros (uma vez que seus resultados estão diretamente ligados à quantidade de comissões e taxas obtidas a partir dos negócios realizados em pregões pelas sociedades corretoras membros), iniciaram um processo de "fusão", por meio do qual as bolsas de valores de diversos

\footnotetext{
${ }^{18}$ O Plano de Ação Econômica do Governo - PAEG tinha por objetivo, dentre outros, diminuir a inflação

19 Resende, André Lara (1990). Estabilização e reforma: 1964-1967. In Abreu, M. (org.), A Ordem Do Progresso, Rio de Janeiro. Campus.
} 
estados realizavam acordos entre si de modo a formar verdadeiros conglomerados.

Como se pode depreender da "Publicação sobre o Mercado de Capitais", divulgada pela CVM em abril de $1997^{20}$, havia, no mesmo ano, apenas nove bolsas de valores no Brasil (número que já havia atingido 27 no passado), o que demonstra, de maneira cristalina, o mencionado processo de consolidação. Eram elas as seguintes bolsas de valores: (i) Bolsa de Valores do Rio de Janeiro - BVRJ; (ii) Bolsa de Valores de São Paulo - BOVESPA; (iii) Bolsa de Valores Bahia-Sergipe-Alagoas BVBSA; (iv) Bolsa de Valores Minas Gerais-Espírito Santo-Brasília BOVMESB; (v) Bolsa de Valores do Extremo Sul - BVES (Rio Grande do Sul e Santa Catarina); (vi) Bolsa de Valores do Paraná - BVPR; (vii) Bolsa de Valores Pernambuco-Paraíba - BVPP; (viii) Bolsa de Valores Regional - BVRg (CE-RN-PI-MA-PA-AM); e (xix) Bolsa de Valores de Santos BVSt.

\section{a) Processo de Integração das Bolsas de Valores}

Como melhor descrito acima, o processo de evolução das bolsas de valores, que consistiu em mais de um século de avanços e inovações, resultou em um cenário no qual se puderam verificar, no ano de 2001, nove bolsas de valores independentes exercendo as mesmas atividades, porém em localidades distintas.

Contudo, o Brasil não mais enfrentava o mesmo cenário de 50 anos atrás, mas sim um cenário de internacionalização da economia brasileira, onde a forte concorrência das bolsas de valores internacionais, os

\footnotetext{
${ }^{20}$ De acordo com a "Publicação sobre o Mercado de Capitais", divulgada pela CVM em abril de 1997, a BOVESPA teria sido responsável, no ano de 1996, pela maior parte (84\%) dos negócios em bolsa de valores no país. As outras oito bolsas estão integradas no Sistema Eletrônico de Negociação Nacional - SENN e responderiam por cerca de $16 \%$ do volume total.
} 
investimentos externos abundantes, a evolução da maturidade do investidor brasileiro, a necessidade de uma competitividade econômica perante o cenário internacional e, principalmente, a forte concorrência interna das bolsas de valores, isto é, das Bolsas de Valores do Rio de Janeiro e de São Paulo, influenciavam de maneira incisiva os resultados das bolsas de valores no Brasil. Soma-se a isso o fato das bolsas de valores regionais enfrentarem problemas financeiros que, em um dado momento, tornaram-se irreversíveis, principalmente em razão dos elevados custos face à ausência de investimentos em tecnologia.

Com o crescimento acentuado - para não dizer quase que exclusivo dos Estados do Rio de Janeiro e São Paulo, esmagadora parcela das operações de natureza bursátil, a partir a década de 1980, passaram a ocorrer, naturalmente, nas bolsas de valores com sede em tais estados, causando o inevitável esvaziamento das bolsas de valores regionais.

Não se pode dizer com precisão quando ocorreram os baques que culminaram, finalmente, na unificação das bolsas de valores no Brasil - ou até mesmo o que, de fato, ocorreu -, especialmente no que tange ao esvaziamento da Bolsa de Valores do Rio de Janeiro, uma vez que tal movimento ocorreu de forma silenciosa, gradativa e, sobretudo, consistente. Podemos dizer, entretanto, que o elevado crescimento econômico das empresas listadas na Bolsa de Valores de São Paulo, atrelado a uma política de investimentos em tecnologia e na redução de custos (fatores que, definitivamente, contribuíram para o insucesso dos negócios na Bolsa de Valores do Rio de Janeiro), ocasionou a alteração do foco dos negócios para São Paulo.

Diante disso, o passo inicial para a integração das bolsas de valores no Brasil se deu por meio da assinatura de um acordo de integração, celebrado entre as nove bolsas remanescentes no Brasil, por meio do qual a 
Bolsa de Valores do Rio de Janeiro passaria a concentrar a negociação secundária de títulos públicos, e, a Bolsa de Valores de São Paulo, a negociação de títulos privados.

Interessante notar que, ironicamente, a Bolsa de Valores do Rio de Janeiro retornaria, após quase um século, ao papel de centro exclusivo de negociação de títulos públicos, reafirmando uma atividade que exerceu ativamente durante décadas e, praticamente, de maneira isolada.

\section{b) Processo de Desmutualização das Bolsas de Valores}

Como já mencionado acima, as bolsas de valores, em seu modelo tradicional, organizavam-se como associações civis, sem finalidades lucrativas. Tais associações contavam com os corretores membros como seus associados (i.e., tidos como proprietários da bolsa), os quais detinham o direito exclusivo de negociar títulos e valores mobiliários em tais recintos.

Entretanto, em razão do crescimento da competição global no setor bursátil (o que desembocou em uma corrida das sociedades corretoras e dos investidores às bolsas de valores no mundo que lhes oferecessem maiores vantagens), tais entidades iniciaram um processo de competição, ou, no linguajar popular, de "quem oferece mais", que culminou, invariavelmente, em um processo chamado de "desmutualização".

Conceitua-se o processo de desmutualização, resumidamente, como a transformação do tipo societário das bolsas de valores, de associação civil para sociedade anônima com finalidade lucrativa, atribuindo aos seus corretores membros ações dessa nova companhia e, em um momento posterior, a abertura de seu capital, transferindo o seu poder decisório para 
novos acionistas ${ }^{21}$.

Esse processo foi adotado preponderantemente entre os anos de 1990 e 2000, como se pode observar do gráfico abaixo, no qual consta o número de desmutualizações no cenário internacional entre os anos de 1999 e $2004^{22}$ :

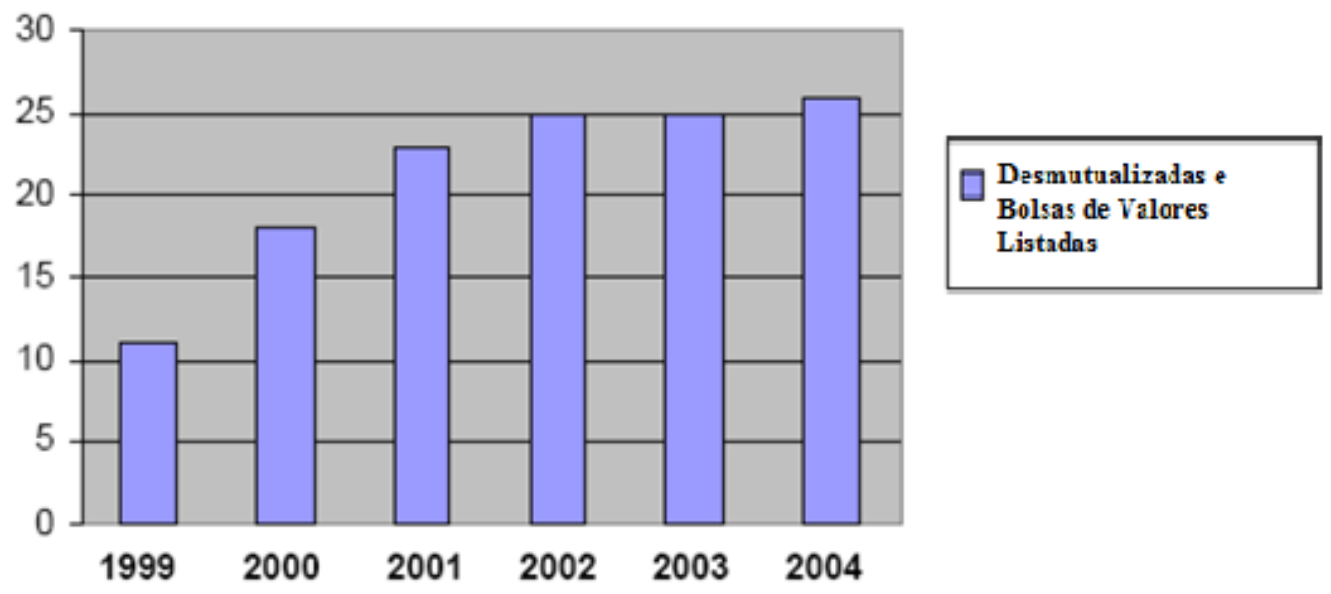

No Brasil, a possibilidade de desmutualização das bolsas de valores se deu somente no ano de 2000, por meio de uma autorização genérica prevista no artigo $1^{\circ}$ da Resolução do $\mathrm{BCB} \mathrm{n}^{\circ} 2.690$, de 28 de janeiro de 2000, conforme alterada ("Resolução BCB 2.690"), o qual dispunha que "as bolsas de valores poderão ser constituídas como associações civis ou sociedades anônimas"(g.n.n.).

Sete anos mais tarde, por meio de diversos dispositivos constantes da "nova Instrução CVM 461", o processo de desmutualização foi efetivamente regulado, passando-se a admitir que bolsas de valores no Brasil se organizassem sob a forma desmutualizada, "como nas regras de admissão das pessoas autorizadas a operar, de composição e competência

\footnotetext{
${ }^{21}$ EIZIRIK, Nelson et al.. Mercado de Capitais Regime Jurídico. $2^{\mathrm{a}}$ ed. Rio de Janeiro: Renovar, 2008. $201 \mathrm{p}$.

${ }^{22}$ Gráfico extraído do Edital de Audiência Pública n 06/2007, de 28 de junho de 2007, que culminou na edição da Instrução CVM 461.
} 
do Conselho de Administração, na estrutura de auto-regulação e nas regras especiais relativas à listagem de suas próprias ações ${ }^{23 ”}$.

Diante dessa nova conjuntura regulatória, a BOVESPA e a Bolsa de Mercadorias e Futuros - BM\&F, antevendo uma maior competição internacional em razão dos processos de desmutualização ocorridos em várias jurisdições (cabe mencionar, ainda, que muitos desses processos originaram verdadeiros conglomerados mundiais de bolsas de valores), iniciaram o seu processo de desmutualização no mesmo ano de 2007, mais precisamente em 28 de agosto e 20 de setembro, respectivamente, transformando-se em sociedades anônimas.

Nesse particular, urge ressaltar que a BM\&FBOVESPA, tal como conhecemos atualmente, é o resultado do processo inicial de desmutualização da Bovespa (denominando-se Bovespa Holding) e da BM\&F (denominando-se BM\&F S.A.) e, posteriormente, de diversos processos de relativa complexidade que, com o objetivo de integrar as atividades de referidas companhias, culminaram na incorporação, pela Nova Bolsa S.A., tanto das ações da BM\&F quanto da Bovespa, dando origem finalmente à BM\&FBOVESPA.

\subsection{A Autorregulação das Bolsas de Valores no Brasil}

Primeiramente, faz-se necessário contextualizar que atividade de autorregulação no mundo não é algo novo, havendo registro de casos em guildas mercantis na Europa do século XII e na Ásia e no Norte da África do século XI, como, por exemplo, as regras dos comerciantes maghribi, que se organizavam em forma de associação e estabeleciam regras de conduta

\footnotetext{
${ }^{23}$ Edital de Audiência Pública n 06/2007, de 28 de junho de 2007, que culminou na edição da Instrução CVM 461.
} 
de maneira semelhante às entidades autorreguladoras atuais ${ }^{24}$.

Assim, e antes de adentrarmos no ponto substancial a que esse capítulo se refere, um ponto importante da autorregulação no mercado de capitais diz respeito à sua assunção em diversas facetas, estas condicionadas ao nível de complexidade do sistema jurídico ao qual a entidade se insere, o grau de sofisticação de seus participantes, bem como o quão vinculada - ou o grau de independência que - tal entidade se encontra perante seu órgão regulador.

Nesse sentido, podemos dizer que o nível de eficácia da autorregulação no mercado de capitais está invariavelmente ligado à forma de atuação de tais entidades, isto é, se de forma complementar ao regulador ou de maneira independente a este. Ainda, destaca-se que, no caso das bolsas de valores no Brasil, a autorregulação, a qual os participantes membros se submetem, vem sendo considerada mais eficaz vis-à-vis o poder regulatório originalmente exercido pelo poder público.

Tradicionalmente, a autorregulação no mercado de capitais brasileiro é - ou deveria ter sido - aquela exercida pelas bolsas de valores. Essa tradição se explica, seja por aspectos históricos, na medida em que a autorregulação exercida pelas bolsas de valores precedeu a própria regulação estatal, seja por aspectos econômicos, considerando a necessidade de garantir a boa formação de preços, fundamental ao sistema das bolsas de valores ${ }^{25}$.

Pode-se dizer que a autorregulação do mercado de capitais no Brasil, até o início de 1990, era bastante incipiente - para não tratarmos como algo

\footnotetext{
${ }^{24}$ FILHO, Luiz Chrysostomo de Oliveira. Mercado de capitais e crescimento econômico - lições internacionais, desafios brasileiros. Rio de Janeiro: Contra Capa, 2005. 226 p.

${ }^{25}$ YAZBEK, Otávio. Regulação do Mercado Financeiro e de Capitais. $2^{\circ}$ ed. Elsevier, 2009. p. 211.
} 
“inexistente". A partir desse momento (i.e., a década de 90), com a evolução do mercado de capitais no Brasil e a emissão de valores mobiliários por companhias abertas no exterior, principalmente American Depositary Receipts ${ }^{26}$, novos standards de governança foram sendo incorporados na cultura corporativa brasileira, padrões esses que serviram de base para diversas regulamentações instituídas no âmbito do seu mercado de valores mobiliários.

Ao longo da década de 1990, essa maturidade regulatória se desenvolveu a passos largos, culminando em um primeiro marco da autorregulação das bolsas de valores no Brasil: a edição da Lei ${ }^{\circ}$ 9.457, a qual veio a alterar a Lei da CVM de forma a constar expressamente o caráter autônomo das bolsas de valores e das entidades de mercado de balcão organizado, e, posteriormente, a edição da Lei $\mathrm{n}^{\circ} 10.303$, de 31 de outubro de 2001, a qual estendeu o conceito para as Bolsas de Mercadorias e Futuros e às entidades de compensação e liquidação de operações com valores mobiliários.

Com efeito, o efetivo exercício dessa atividade de autorregulação se mostrou latente quando, em 2000, a BM\&FBOVESPA instituiu novos segmentos de listagem com níveis diferenciados de governança corporativa,

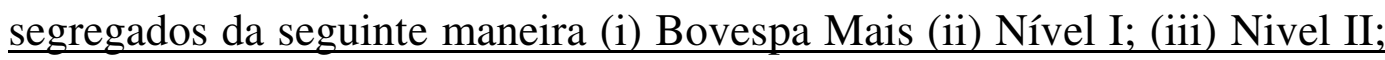
e (iv) Novo Mercado. A criação de novos standards ou parâmetros de governança corporativa, com obrigações às companhias abertas aderentes e eventuais multas em casos de descumprimentos ou inobservâncias, se mostrou bastante eficaz e expressiva ${ }^{27}$, traduzindo uma tendência de certa

\footnotetext{
${ }^{26}$ Ibid. 228 p.

${ }^{27}$ Em maio de 2009, havia 430 empresas listadas na BM\&FBOVESPA, dispostas nos segmentos de listagem da seguinte maneira: (i) 273 companhias listadas no segmento tradicional ou de BDRs; (ii) 40 empresas listadas no segmento de listagem "Nível I"; (iii) 18 companhias listadas no segmento de listagem "Nível II"; (iv) 99 companhias listadas no segmento de listagem "Novo Mercado". Pode-se dizer que grande parte das ofertas públicas realizadas a partir do início da entrada em vigor dos segmentos de listagem com níveis diferenciados de governança corporativa se deu por meio da aderência a algum dos segmentos especiais de listagem. (fonte: Boletim
} 
forma internacional de que as bolsas de valores poderiam, mais "de perto" se comparadas às entidades reguladoras, fiscalizar as atividades desempenhas pelos participantes do mercado. A instituição de tais standards pode ser conceituada como uma autorregulação de "base voluntária", na qual a sua aderência é facultativa, mas as obrigações a partir de sua aderência tornam-se obrigatórias.

Apresentamos abaixo, apenas a título ilustrativo, um comparativo contendo as obrigações atuais de cada segmento de listagem da BM\&FBOVESPA e o segmento tradicional, este traduzindo apenas as exigências normativas constantes da Lei das Sociedades Anônimas e da própria $\mathrm{CVM}^{28}$ :

\begin{tabular}{|c|c|c|c|c|c|}
\hline & $\begin{array}{c}\text { NOVO } \\
\text { MERCADO }\end{array}$ & NÍVEL 2 & NÍVEL 1 & BOVESPA MAIS & $\begin{array}{l}\text { TRADICIONAL } \\
\text { (Mínimo requerido pela Lei das } \\
\text { Sociedades Anônimas) }\end{array}$ \\
\hline $\begin{array}{l}\text { Características das } \\
\text { Ações Emitidas }\end{array}$ & $\begin{array}{l}\text { Permite a } \\
\text { existência } \\
\text { somente de } \\
\text { ações ON }\end{array}$ & \begin{tabular}{|l|} 
Permite a \\
existência de \\
ações ON e PN \\
(com direitos \\
adicionais) \\
\end{tabular} & $\begin{array}{l}\text { Permite a existência } \\
\text { de ações ON e PN } \\
\text { (conforme legislação) }\end{array}$ & $\begin{array}{l}\text { Somente ações ON podem } \\
\text { ser negociadas e emitidas, } \\
\text { mas é permitida a } \\
\text { existência de PN }\end{array}$ & $\begin{array}{l}\text { Permite a existência de ações ON e } \\
\text { PN (conforme legislação) }\end{array}$ \\
\hline $\begin{array}{l}\text { Percentual Mínimo de } \\
\text { Ações em Circulação } \\
\text { (freefloat) }\end{array}$ & \multicolumn{3}{|c|}{ No mínimo $25 \%$ de freefloat } & $\begin{array}{l}25 \% \text { de freefloat até o } 7^{\circ} \\
\text { ano de listagem, ou } \\
\text { condições mínimas de } \\
\text { liquidez }\end{array}$ & Não há regra \\
\hline $\begin{array}{l}\text { Distribuiçõoes públicas } \\
\text { de ações }\end{array}$ & \multicolumn{3}{|c|}{ Esforços de dispersão acionária } & \multicolumn{2}{|c|}{ Não há regra } \\
\hline $\begin{array}{l}\text { Vedação a disposições } \\
\text { estatutárias (a partir de } \\
\text { 10/05/2011) }\end{array}$ & \multicolumn{2}{|c|}{$\begin{array}{l}\text { Limitação de voto inferior a } \\
5 \% \text { do capital, quorum } \\
\text { qualificado e "cláusulas } \\
\text { pétreas" }\end{array}$} & \multicolumn{3}{|c|}{ Não há regra } \\
\hline $\begin{array}{l}\text { Composição do } \\
\text { Conselho de } \\
\text { Administração }\end{array}$ & \multicolumn{2}{|c|}{$\begin{array}{l}\text { Mínimo de } 5 \text { membros, dos } \\
\text { quais pelo menos } 20 \% \\
\text { devem ser independentes } \\
\text { com mandato unificado de } \\
\text { até } 2 \text { anos }\end{array}$} & \multicolumn{3}{|c|}{ Mínimo de 3 membros (conforme legislação) } \\
\hline $\begin{array}{l}\text { Vedação à acumulação } \\
\text { de cargos (a partir de } \\
\text { 10/05/2011) }\end{array}$ & \multicolumn{3}{|c|}{$\begin{array}{l}\text { Presidente do conselho e diretor presidente ou } \\
\text { principal executivo pela mesma pessoa (carência } \\
\text { de } 3 \text { anos a partir da adesão) }\end{array}$} & \multicolumn{2}{|r|}{ Não há regra } \\
\hline $\begin{array}{l}\text { Obrigação do Conselho } \\
\text { de Administração (a } \\
\text { partir de 10/05/2011) }\end{array}$ & \multicolumn{2}{|c|}{\begin{tabular}{|l|} 
Manifestação sobre \\
qualquer oferta pública de \\
aquisição de ações da \\
companhia
\end{tabular}} & \multicolumn{3}{|c|}{ Não há regra } \\
\hline \begin{tabular}{|l} 
Demonstrações \\
Financeiras
\end{tabular} & \multicolumn{2}{|c|}{ Traduzidas para o inglês } & \multicolumn{3}{|c|}{ Conforme legislação } \\
\hline
\end{tabular}

Informativo do Novo Mercado, ano 8, $\mathrm{n}^{\mathrm{o}}$ 144, maio de 2009, disponível para consulta em http://www.bovespa.com.br/pdf/BoletimInformativo144.pdf)

${ }^{28} \mathrm{http}: / / \mathrm{www}$. bmfbovespa.com.br/empresas/pages/empresas_segmentos-de-listagem.asp 


\begin{tabular}{|c|c|c|c|c|c|}
\hline & $\begin{array}{c}\text { NOVO } \\
\text { MERCADO }\end{array}$ & NÍVEL 2 & NÍVEL 1 & BOVESPA MAIS & $\begin{array}{c}\text { TRADICIONAL } \\
\text { (Mínimo requerido pela Lei das } \\
\text { Sociedades Anônimas) }\end{array}$ \\
\hline $\begin{array}{l}\text { Reunião pública anual e } \\
\text { calendário de eventos } \\
\text { corporativos }\end{array}$ & \multicolumn{3}{|c|}{ Obrigatório } & \multicolumn{2}{|r|}{ Facultativo } \\
\hline $\begin{array}{l}\text { Divulgaçãa adicional de } \\
\text { informações (a partir de } \\
\text { 10/05/2011) }\end{array}$ & \multicolumn{3}{|c|}{$\begin{array}{l}\text { Política de negociação de valores mobiliários e } \\
\text { código de conduta }\end{array}$} & \multicolumn{2}{|c|}{ Não há regra } \\
\hline Concessão de TagAlong & $\begin{array}{l}100 \% \text { para } \\
\text { ações ON }\end{array}$ & \begin{tabular}{|l|}
$100 \%$ para \\
ações ON e PN \\
$100 \%$ para \\
ações ON e \\
$80 \%$ para PN \\
(até \\
$09 / 05 / 2011)$ \\
\end{tabular} & $\begin{array}{l}80 \% \text { para ações ON } \\
\text { (conforme legislação) }\end{array}$ & $100 \%$ para ações ON & $\begin{array}{l}80 \% \text { para ações ON (conforme } \\
\text { legislação) }\end{array}$ \\
\hline \begin{tabular}{|l|} 
Oferta pública de \\
aquisição de ações no \\
mínimo pelo valor \\
econômico
\end{tabular} & \multicolumn{2}{|c|}{$\begin{array}{l}\text { Obrigatoriedade em caso de } \\
\text { fechamento de capital ou } \\
\text { saída do segmento }\end{array}$} & Conforme legislação & $\begin{array}{l}\text { Obrigatoriedade em caso } \\
\text { de fechamento de capital } \\
\text { ou saída do segmento }\end{array}$ & Conforme legislação \\
\hline \begin{tabular}{|l|} 
Adesão à Câmara de \\
Arbitragem do Mercado
\end{tabular} & \multicolumn{2}{|c|}{ Obrigatório } & Facultativo & Obrigatório & Facultativo \\
\hline
\end{tabular}

Nesse sentido, os segmentos de listagem de governança corporativa diferenciada foram criados em uma conjuntura na qual os próprios membros do mercado, sejam bancos de investimento, associações ou companhias abertas, sentiam-se vulneráveis com relação a algumas normas previstas na Lei das Sociedades por Ações (como foi o caso do direito de tag along ${ }^{29}$ ).

Contudo, e não obstante os inegáveis esforços da BM\&FBOVESPA para implementar um sistema autorregulatório que assegurasse a todos os participantes do mercado condições mínimas de proteção, podemos encontrar atualmente algumas situações conflitantes inerentes ao sistema adotado no Brasil (isto é, de uma sociedade anônima autorreguladora e independente junto à CVM), as quais passamos a expor brevemente abaixo.

\footnotetext{
${ }^{29}$ Em breves palavras, o tag along confere aos acionistas minoritários o direito de exercerem seu direito de retirada, em caso de aquisição do controle de determinada companhia aberta por investidor estranho à sociedade, por um determinado percentual do valor ofertado ao controlador da sociedade. A Lei das Sociedades por Ações prevê, atualmente, o direito de Tag Along no montante relativo a $80 \%$ do valor ofertado, ao passo que alguns níveis de governança corporativa da BM\&FBOVESPA conferem aos investidores o montante de 100\% do valor pago, isto é, o mesmo valor oferecido ao acionista controlador.
} 
Primeiramente, cumpre ressaltar o conceito de autorregulação fundamentalmente exposto na Instrução CVM 461, isto é, de "enforcement", consistindo na fiscalização e supervisão, pelas bolsas de valores (mais precisamente a BM\&FBOVESPA), dos seus entes conveniados.

Nesse sentido, a primeira incoerência que podemos levantar sobre esse sistema brasileiro reside no fato da BM\&FBOVESPA, sociedade empresária com finalidades econômicas e de capital aberto, ter por objetivo desenvolver, da forma mais eficaz possível, a manutenção e administração de um ambiente cujo objetivo reside na viabilização da realização de operações bursáteis. Nesse mister - ressaltamos - reside o conflito de interesses a que nos referimos inicialmente, uma vez que a clientela da bolsa, ou seja, as pessoas que fornecem as receitas por ela auferidas, são invariavelmente os participantes que a própria bolsa tem o dever de fiscalizar e, ultima ratio, a quem deve impor sanções.

A mencionada fiscalização e, em última instância, imposição de determinada sanção, poderia não ser exercida da maneira mais eficiente, visto que a atuação mais severa da BM\&FBOVESPA junto aos seus "clientes" poderia ocasionar uma diminuição dos negócios por ela administrados e, ato contínuo, das receitas por ela auferidas. Estaria a bolsa de valores, portanto, impelida a realizar uma verdadeira "escolha de sofia", qual seja: (i) não exercer da maneira que se espera seus deveres de "enforcement", ocasionando um aumento - ou pelo menos a estabilidade de suas receitas; ou (ii) exercer de maneira plena os deveres inerentes à sua finalidade, mas correndo o risco de vislumbrar um decréscimo do volume de negócios e, consequentemente, de suas receitas.

Por fim, outro ponto que poderia influenciar - ou até agravar - esse viés dúplice da atuação das bolsas de valores é o aumento da integração dos 
mercados de capitais no mundo e a atual facilidade com que as sociedades corretoras, companhias abertas e investidores conseguem atingir tais mercados. Essa facilidade pode fazer com que, a qualquer momento, todos os participantes redirecionem seus negócios para outras bolsas de valores caso a BM\&FBOVESPA tome atitudes contrárias às vontades de seus participantes.

No que tange à Instrução CVM 461, e como já dito acima, podemos dizer que a mesma normatizou as atividades relativas à autorregulação dos mercados organizados de valores mobiliários (i.e., precipuamente as atividades exercidas atualmente pela BM\&FBOVESPA, sabidamente a única bolsa de valores efetivamente em exercício no Brasil), “externalizando" o espírito do artigo 17 da Lei da CVM, o qual preconiza que as "Bolsas de Valores, as Bolsas de Mercadorias e Futuros, as entidades do mercado de balcão organizado $e$ as entidades de compensação e liquidação de operações com valores mobiliários terão autonomia administrativa, financeira e patrimonial" (grifamos). Ainda, o artigo $8^{\circ}, \S 1^{\circ}$, ao tratar do âmbito de competência da CVM, expõe que "o disposto neste artigo não exclui a competência das Bolsas de Valores, das Bolsas de Mercadorias e Futuros, e das entidades de compensação e liquidação com relação aos seus membros e aos valores mobiliários nelas negociados".

Nesse mesmo sentido, a Instrução CVM 461, em seu artigo 36, dispôs sobre a estrutura da autorregulação, senão vejamos:

"Art. 36.O Departamento de Auto-Regulação, o Diretor do Departamento de Auto-Regulação e o Conselho de Auto-Regulação são os órgãos da entidade administradora encarregados da fiscalização e supervisão das operações cursadas nos mercados organizados de valores mobiliários que estejam sob sua responsabilidade, das pessoas autorizadas a neles operar, bem como das atividades de organização e acompanhamento de mercado desenvolvidas pela 
própria entidade administradora."

Como se pode observar, o referido artigo corrobora nossos argumentos quanto à natureza das bolsas de valores e sua atividade autorreguladora ao instituir que as mesmas deverão fiscalizar e supervisionar todas as operações cursadas em ambiente bursátil.

Mais a frente, a Instrução CVM 461, em seu $§ 3^{\circ}$, artigo 36, instituiu uma faculdade para as bolsas de valores, em seu mister da autorregulação, de constituírem "associação, sociedade controlada, ou submetida a controle comum, de propósito específico, que exerça as funções de fiscalização e supervisão" ${ }^{, 30}$.

\footnotetext{
${ }^{30}$ Em virtude da mencionada faculdade, a BM\&FBOVESPA decidiu constituir, em outubro de 2007, a BM\&FBOVESPA Supervisão de Mercados - BSM, uma associação privada sem finalidades lucrativas cujo objeto reside no exercício das funções de fiscalização e supervisão dos participantes do mercado.
} 


\section{Capítulo 3. A Autorregulação das Bolsas de Valores e a Regulação da CVM no Mercado de Capitais Brasileiro}

Como brevemente exposto acima, o sistema do mercado de capitais no Brasil comporta a regulação originária outorgada por meio de ato legislativo e exercida pela CVM, bem como a autorregulação dos mercados organizados de valores mobiliários, esta exercida pelas entidades do mercado de balcão organizado e às entidades de compensação e liquidação de operações com valores mobiliários.

Nesse sentido dispõe o artigo $17, \S 1^{\circ}$, da Lei da CVM, senão vejamos:

"Art. 17. As Bolsas de Valores, as Bolsas de Mercadorias e Futuros, as entidades do mercado de balcão organizado e as entidades de compensação e liquidação de operações com valores mobiliários terão autonomia administrativa, financeira e patrimonial, operando sob a supervisão da Comissão de Valores Mobiliários.

$\S 1^{\circ}$ Às Bolsas de Valores, às Bolsas de Mercadorias e Futuros, às entidades do mercado de balcão organizado e às entidades de compensação e liquidação de operações com valores mobiliários incumbe, como órgãos auxiliares da Comissão de Valores Mobiliários, fiscalizar os respectivos membros e as operações com valores mobiliários nelas realizadas."

(grifos nossos)

Como registrado acima, há que se distinguir as atividades desempenhadas pelo órgão regulador vis-à-vis o órgão autorregulador, delimitando, principalmente, a fronteira de atuação das entidades autorreguladoras diante do mercado, bem como sua natureza de ente supervisionado pelo órgão regulador. 
A CVM, como missão, possui o poder de regular, fiscalizar e promover o desenvolvimento do mercado de valores mobiliários no Brasil, tendo como esfera de competência, basicamente, (i) companhias abertas; (ii) intermediários financeiros (e.g., auditores e bancos de investimento); (iii) investidores em geral; e (iv) demais segmentos que giram em torno do mercado de valores mobiliários. Posto isso, a CVM tem como principais objetivos (a) a proteção dos titulares de valores mobiliários contra emissões de valores mobiliários irregulares e atos ilegais de entidades reguladas; (b) evitar ou coibir modalidades de fraude ou manipulação; (c) zelar pela observância de práticas equitativas no mercado; e (d) assegurar o acesso do público em geral a informações sobre valores mobiliários (i.e., "princípio da ampla divulgação de informações").

Por outro lado, as bolsas de valores, na qualidade órgãos autorreguladores, fundamentam-se em algumas premissas, tais como:

(i) A ação eficaz e única da CVM sobre o mercado de valores mobiliários em geral implicaria em custos excessivamente altos, o que poderia não ser útil quando se quer, cada vez mais, elevar a eficiência e abrangência do mercado;

(ii) As bolsas de valores, pela sua proximidade das atividades de mercado e melhor conhecimento das mesmas, disporia de maior sensibilidade para avaliá-las e normatizá-las, podendo agir com maior efetividade e com custos reduzidos (se comparado aos custos potencialmente suportados pela CVM para realização das mesmas atividades); e

(iii) A elaboração e a aceitação, pelos entes supervisionados das bolsas de valores, das normas que disciplinam suas atividades fazem com que haja uma maior receptividade dessas normas e 
com que tais participantes de mercado se sintam mais responsáveis por seu cumprimento (o que, a nosso ver, não diminuiria a necessidade de intervenção do órgão regulador em determinados casos).

Com efeito, a supervisão exercida pela CVM sobre as bolsas de valores pode ser considerada semelhante àquela exercida pelo Poder Executivo sobre as entidades da administração indireta ${ }^{31}$. Assim, a orientação e verificação das atividades exercidas pelas bolsas de valores devem ser realizadas pela CVM na qualidade de ente supervisor, sempre zelando pelos princípios e finalidades instituídos às bolsas de valores e de foram a aumentar a eficiência da atividade regulatória, evitando a centralização excessiva do poder de editar normas e fiscalizar o seu cumprimento.

Como é sabido, o arcabouço legal do mercado de capitais pátrio é calcado no princípio de que a fiscalização (i) dos participantes filiados às bolsas de valores (e.g., sociedades corretoras); e (ii) das operações bursáteis realizadas, competiria, precipuamente, às bolsas de valores. Restaria à CVM, portanto, a atividade de supervisão dessas atividades autorregulatórias, pautando seu mister na tutela do - e tendo em vista o interesse público.

É cristalino, assim, o modo pelo qual a segurança e a efetividade do mercado de capitais no Brasil são, atualmente, asseguradas, conforme tabela ilustrativa abaixo:

\footnotetext{
${ }^{31}$ EIZIRIK, Nelson et al.. Mercado de Capitais Regime Jurídico. $2^{\mathrm{a}}$ ed. Rio de Janeiro: Renovar, 2008. $196 \mathrm{p}$.
} 


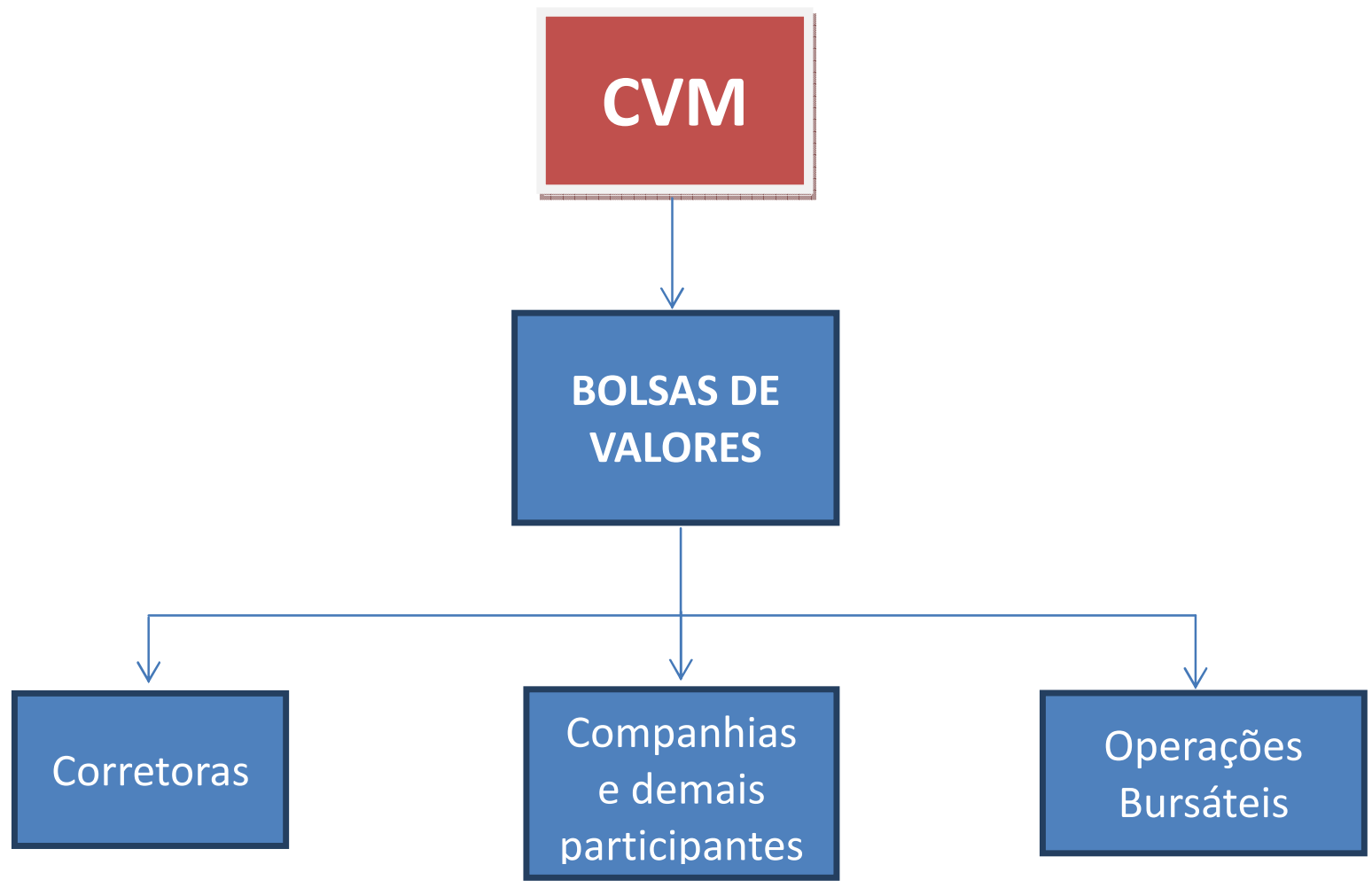

Como dito mais acima, a Instrução CVM 461 reconheceu a importância da autorregulação tanto com relação ao seu mister normativo quanto ao seu mister fiscalizador. No entanto, o reconhecimento às bolsas de valores exarado na Instrução CVM 461 não é de todo absoluto; como se pode observar, o artigo 15 da Instrução CVM 461, em seu parágrafo único, dispõe que a CVM "poderá recusar a aprovação das regras ou exigir alterações, sempre que as considere insuficientes para o adequado funcionamento do mercado de valores mobiliários, ou contrárias a disposição legal ou regulamentar".

Outro fato apto a demonstrar o caráter auxiliar das bolsas de valores junto à CVM está disposto nessa mesma instrução, em seu artigo 115, quando são abordadas as hipóteses de cancelamento de autorização para funcionamento de entidade administradora ou para funcionamento de mercado organizado, as quais se darão "se ficar comprovado que a entidade deixou de acatar determinação da CVM ou não tem capacidade para observar, e zelar pela observância, por parte das pessoas autorizadas a 
operar, de suas regras e contratos, bem como da lei e da regulamentação da CVM'.

Por outro lado, cabe questionamento quanto à reforma de decisão de entidade autorreguladora pela entidade reguladora do mercado de capitais. Nesse sentido, foi instaurado determinado processo administrativo perante a $\mathrm{CVM}^{32}$ para apurar, dentre outros, a responsabilidade da Bolsa de Valores de Minas, Espírito Santo e Brasília e de seu Superintendente Geral quanto à suposta ausência de apuração de infrações às normas regulamentares praticadas por corretora de valores, entendeu que não caberia ao órgão regulador realizar o julgamento de uma decisão proferida em processo instaurado - e já julgado - por entidade autorreguladora.

Alguns problemas pontuais - a nosso ver - poderiam surgir a partir desse entendimento, pelo que passaremos a expor brevemente abaixo. No entanto, importa destacar, a titulo de contextualização, o referido entendimento:

"De outro lado, não pode a CVM pretender punir o auto-regulador quando diverge da medida adotada pelo auto-regulador. Não me parece que caiba julgar o julgamento. $O$ auto-regulador tem competência para tomar as medidas que entender conveniente e se as medidas tomadas são diferentes daquelas que a CVM entende adequadas, é uma questão de julgamento, de opinião e daí não advém, segundo penso, responsabilidade disciplinar. Não ficou caracterizada negligência, ressalvo. Quanto mais, ressalve-se, quando se fala de aferição de indícios e provas, onde incide, inequivocamente, o princípio do livre convencimento.

E não é por outra razão, aliás, que a regulação dispõe expressamente que o poder disciplinar das bolsas de valores não exclui o da CVM e sendo assim a CVM pode adotar os procedimentos que entender adequado, como aliás o fez no

\footnotetext{
${ }^{32}$ Processo Administrativo Sancionador n ${ }^{\circ}$ 32/98, julgado em 6 de maio de 2004.
} 
presente caso.

Dito isto, conforme está provado nos autos, a Bovmesb fiscalizou e nos seus relatórios de auditoria encontrou as irregularidades, adotou procedimentos, fez recomendações e, inclusive, causou ressarcimento por parte destes reclamantes pela Multicred. A Multicred ressarciu.

À luz desses atos, a Bolsa de Minas entendeu que não seria necessário prosseguir com os procedimentos administrativos. E eu tenho aqui uma posição, que repito não é nova, que quando se delega para a auto-regulação - e nesse sentido, num primeiro momento, pelo menos, quem delega abre mão de exercer o julgamento - não compete, no meu modo de ver, por discordar do julgamento e entender que um ou outro caminho deveria ser tomado ou seria mais indicado, por isso punir a pessoa que exerceu seu julgamento de uma forma razoável, ainda que não seja, no entendimento da Comissão de Valores Mobiliários ou de quem quer que seja, o julgamento que entende melhor. Essas cabeças podem pensar diferentemente. Então, dessa forma, tendo em vista que foram tomados e adotados os procedimentos, eu entendo que não cabe à CVM, nesse caso específico, fazer o juízo de valor a respeito do julgamento e dos atos tomados pela Bolsa de Valores. E, por essa razão, a absolvo e a seu Superintendente da imputação que lhes foi feita."

Não podemos deixar de nos questionar, nessa linha, se seria razoável suportar uma decisão proferida por determinada entidade autorreguladora cujo teor consistiria em entendimento diametralmente oposto ao estabelecido pelo órgão regulador...

Entendemos ser pacífica a linha de atuação a ser traçada entre as entidades reguladoras e autorreguladoras, isto é, em paralelo e em sentido semelhante, tal como duas vias de mão única. Vislumbrar-se-ia, então, um cenário no qual todos os entes supervisionados teriam a necessária segurança jurídica para praticar todo e qualquer ato permitido pela regulação sem que haja temor quanto a possíveis entendimentos divergentes exarados pelas entidades que, ao fim do dia, fiscalizam o mesmo mercado. 
No entanto, em alguns casos, especialmente no que se refere ao mecanismo de ressarcimento de prejuízos mantido e administrado pela BSM, já conseguimos observar decisões proferidas pela referida entidade autorreguladora que, supostamente, teriam divergido do entendimento já proferido pela CVM, e, mais além, ao que a própria Instrução CVM 461 institui (como abordaremos no Capítulo 5.3. A Instrução CVM 461 e as Hipóteses de Acionamento do MRP).

Por isso, em se tratando do sistema do mercado de capitais, no qual o duplo grau de fiscalização é um de seus pilares, há que se envidar melhores esforços para que ambos os órgãos fiscalizadores trabalhem de maneira cooperada, complementar e, em última análise, alinhada. 


\section{Capítulo 4. A BM\&FBOVESPA Supervisão de Mercados - BSM}

\subsection{A BSM como Entidade Autorreguladora e suas Atribuições}

A BM\&FBOVESPA Supervisão de Mercados - BSM, como o próprio nome aponta, é uma associação civil sem finalidade lucrativa cuja responsabilidade reside na supervisão dos mercados mantidos e administrados pela BM\&FBOVESPA. A BSM veio a ser constituída em um momento no qual a entidade reguladora do mercado de capitais, por meio da edição da Instrução CVM 461, permitiu a segregação das atividades de autorregulação das atividades inerentes às bolsas de valores, podendo ser aquelas realizadas com a constituição de associações, sociedades controladas, etc. Seria ela, portanto, o órgão autorregulador-fiscalizador que atuaria em conjunto com a CVM para assegurar o correto funcionamento e o fortalecimento da integridade dos mercados oferecidos pela BM\&FBOVESPA.

A BSM iniciou suas atividades em $1^{\circ}$ de outubro de 2007 , tendo sido declaradamente constituída à luz dos melhores padrões internacionais de supervisão e fiscalização privada dos mercados de bolsa e dos marcos de excelência regulatória pública dos mercados de valores mobiliários, mundialmente reconhecidos ${ }^{33}$.

Tal associação tem por objeto zelar pela integridade dos mercados administrados pela BM\&FBOVESPA, sendo referência nacional e mundial para alguns em autorregulação de mercados. Compromete-se, ainda, a contribuir para a formação e aperfeiçoamento de um mercado de capitais diversificado, saudável, moderno e seguro, imprescindível para a evolução

\footnotetext{
${ }^{33}$ Fonte: http://www.bovespasupervisaomercado.com.br/QuemSomos.asp
} 
econômica de um país.

A atividade de supervisão da BSM consiste, então, no emprego, de forma coordenada e contínua, de procedimentos de monitoramento dos mercados administrados pela BM\&FBOVESPA, visando a detecção de desvios que possam estar relacionados à realização de operações irregulares.

$\mathrm{Na}$ qualidade de entidade autorreguladora dos mercados administrados pela BM\&FBOVESPA, a BSM possui diversas atribuições com o intuito de fiscalizar e supervisionar as operações realizadas naquele ambiente. Nesse sentido, em cumprimento ao disposto na regulamentação de mercado de capitais, a BSM tem por objeto, como previsto no artigo $3^{\circ}$ de seu Estatuto Social, o quanto segue:

(i) analisar, supervisionar e fiscalizar:

(a) as operações e atividades de Participantes; e

(b) o cumprimento das normas legais, regulamentares e operacionais emitidas pelos órgãos reguladores e autorreguladores a que estejam sujeitos os Participantes e as áreas operacionais da BM\&FBOVESPA, inclusive em relação à fiscalização do cumprimento das obrigações dos Emissores, apontando as deficiências verificadas no cumprimento das referidas normas e acompanhando os programas e as medidas adotadas para saná-las.

(ii) manifestar-se, no âmbito de sua competência, sobre a adequação e eficácia das normas regulamentares e operacionais editadas pela BM\&FBOVESPA; 
(iii) tomar conhecimento de reclamações quanto ao funcionamento dos mercados organizados e administrados pela BM\&FBOVESPA, acompanhando seu andamento e as medidas adotadas para saná-las;

(iv) instaurar, instruir, conduzir e julgar processos administrativos e disciplinares para apurar as infrações às normas cujo cumprimento lhe incumbe fiscalizar;

(v) aplicar, no limite de sua competência, penalidades em caso de infrações às suas próprias normas e às normas legais, regulamentares e operacionais e julgar os recursos contra as penalidades aplicadas;

(vi) administrar o MRP, nos termos da regulamentação estabelecida pela CVM;

(vii) julgar as reclamações dirigidas por investidores ao MRP, nos termos da regulamentação estabelecida pela CVM;

(viii) colaborar com entidades nacionais ou estrangeiras congêneres, ou com outras que tenham por objeto discutir e deliberar sobre temas relativos às atividades desenvolvidas por seus Associados e pela própria BSM;

(ix) participar de fóruns ou entidades nacionais e estrangeiras que visem promover estudos, debates ou deliberações sobre temas relativos à autorregulação do mercado de valores mobiliários;

(x) estabelecer normas e os regulamentos necessários ao desempenho de suas funções;

(xi) atestar que a admissão à negociação na BM\&FBOVESPA está em conformidade com os requisitos previstos nas regras 
aplicáveis aos demais emissores, bem como monitorar continuamente esta conformidade;

(xii) fiscalizar as operações com valores mobiliários de emissão da BM\&FBOVESPA, com observância das restrições e limites estabelecidos em normas estatutárias, legais e contratuais, vedada a fiscalização por amostragem;

(xiii) organizar e oferecer cursos, palestras ou treinamentos referentes às atividades previstas no seu objeto social; e

(xiv) exercer outras atividades expressamente autorizadas pela CVM.

Diferentemente da entidade reguladora do mercado de capitais, frisamos que a BSM, no mister de sua função julgadora (hipóteses dos itens (iv) e (v) acima), somente possui competência para julgar as irregularidades praticadas pelas seguintes pessoas:

(i) Associados da BSM;

(ii) $\mathrm{BM} \& \mathrm{FBOVESPA}$;

(iii) Conselheiros, empregados e prepostos da BSM;

(iv) Administradores, empregados e prepostos dos Associados, da BM\&FBOVESP A e quem os representa perante a BSM;

(v) Participantes autorizados a operar nos mercados administrados pela BM\&FBOVESPA e respectivos administradores, empregados, representantes, operadores e prepostos; e 
(vi) Agentes que atuam ou desenvolvam atividades nos sistemas de liquidação e custódia administrados pela CBLC e respectivos administradores, empregados, representantes, operadores e prepostos.

De forma a demonstrar o árduo - e reconhecido - trabalho desempenhado pela BSM, colacionamos abaixo gráfico expondo, numericamente, os trabalhos de autorregulação desempenhados pela BSM no ano de 2011, comparativamente aos anos de 2010 e $2009^{34}$ :

\section{Supervisão de Mercados em Números}

\begin{tabular}{|c|c|c|c|c|c|c|}
\hline \multirow{2}{*}{ Tipos de análise } & \multicolumn{2}{|c|}{2009} & \multicolumn{2}{|c|}{2010} & \multicolumn{2}{|c|}{2011} \\
\hline & Análises & Relatórios & Análises & Relatórios & Análises & Relatórios \\
\hline $\begin{array}{l}\text { Comportamento dos preços e da liquidez dos } \\
\text { ativos e derivativos (condições artificiais de } \\
\text { demanda, oferta ou preço, manipulação de } \\
\text { preços, operações fraudulentas, práticas não } \\
\text { equitativas etc). }\end{array}$ & 4.615 & 25 & 5.181 & 32 & 2.166 & 71 \\
\hline $\begin{array}{l}\text { Participação dos investidores (operações } \\
\text { fraudulentas, lavagem de dinheiro, exercício } \\
\text { irregular de atividade no mercado de valores } \\
\text { mobiliários etc.). }\end{array}$ & 2.124 & 31 & 211 & 25 & 408 & 37 \\
\hline $\begin{array}{l}\text { Observância do regulamento operacional da } \\
\text { BM\&FBOVESPA e normas da CVM (IN CVM } \\
168,358 \text { etc.). (1) }\end{array}$ & 5.931 & 10 & 5.854 & 3 & 2.143 & 1 \\
\hline $\begin{array}{l}\text { Solicitações da CVM e de outras entidades } \\
\text { autorizadas ou departamentos da BSM }\end{array}$ & n.d & 15 & 431 & 13 & 272 & 14 \\
\hline Total & 12.670 & 81 & 11.677 & 73 & 4.989 & 123 \\
\hline $\begin{array}{l}\text { Percentual de assertividade da análise } \\
\text { (Relatórios / Análise) }\end{array}$ & & $0,6 \%$ & & $0,6 \%$ & & $2,5 \%$ \\
\hline
\end{tabular}

(1) A redução, observada em 2011, do número de análises relativos à fiscalização das regras das Instruções 168,286 e 358 deve-se ao fato desta atividade ter migrado para a Diretoria de operações da BM\&FBOVESPA, cabendo à BSM fiscalizar seu cumprimento pela Bolsa.

Nesse mesmo sentido, colacionamos abaixo gráfico contendo processos administrativos instaurados em 2011 pela BSM, segregados por matéria, bem como, em seguida, o resultado dos processos administrativos

\footnotetext{
${ }^{34}$ Relatório das Atividades da BSM em 2011, disponível para consulta em http://www.bovespasupervisaomercado.com.br/InstDownload/Relatorio-de-Atividades-2011.pdf
} 
encerrados por aquela entidade, com relação aos três exercícios anteriores ${ }^{35}$ :

\section{Matéria dos Processos Administrativos instaurados em 2011}

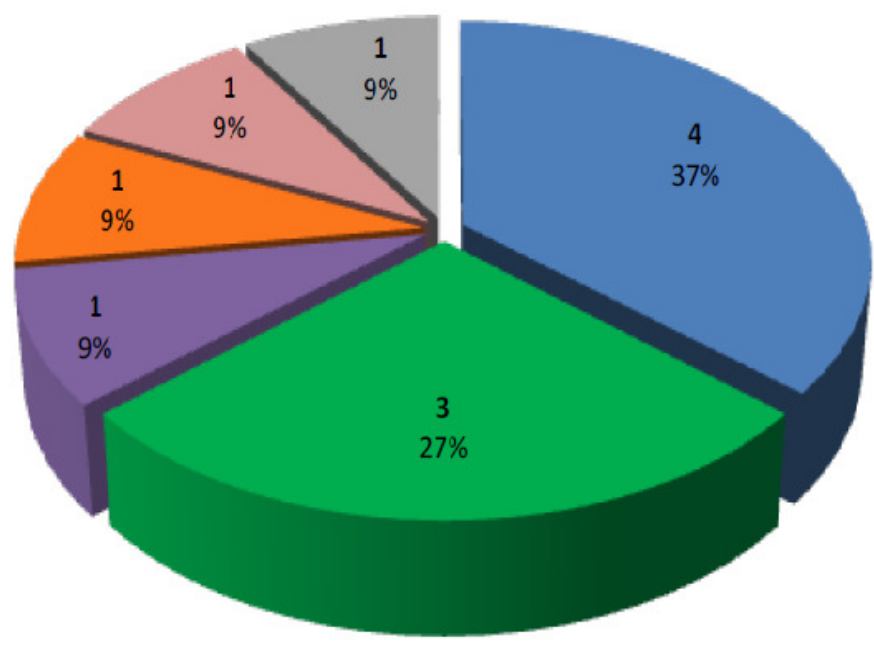

-Falhas nos controles $\mathrm{e}$

procedimentos operacinoais - Administração irregular ce carteira

- Manipulação de preços

- Indícios de lavagem de dinheiro

- Inexecução ou infiel execução ce ordens

Descumprimento de determinação da BSM

Resultado dos Processos Administrativos Encerrados

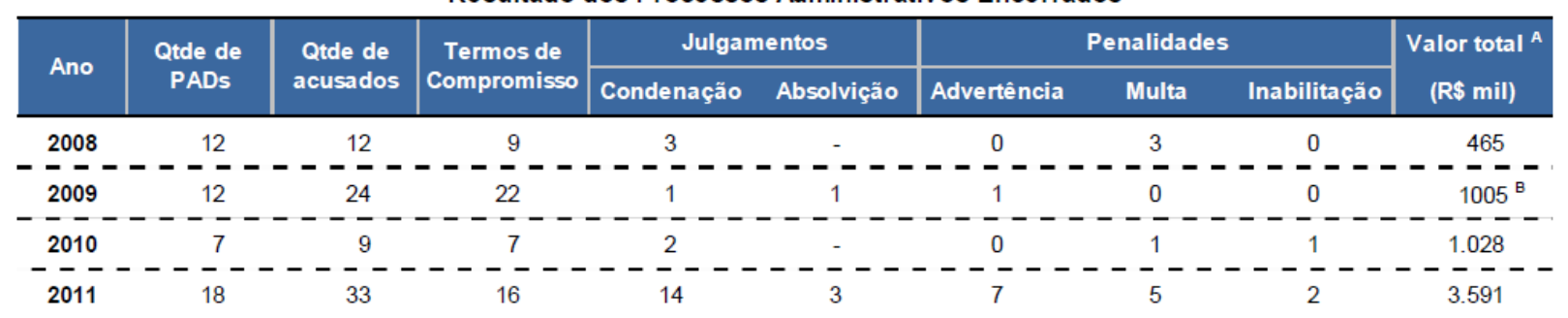

(A) O valor total corresponde à soma das multas aplicadas e das parcelas pecuniárias de termos de compromisso firmados. Emambos os casos, é considerado o total do valor pago pelos acusados envolvidos nos processos encerrados no respectivo ano.

(B) Inclui um Termo de Compromisso assinado no âmbito de um inquérito (INQ-019/2008).

Ainda, cumpre ressaltar que a BSM, de forma a manter a imparcialidade que requer suas atividades, possui autonomia financeira e orçamentária, pessoal especializado e poderá dispor de recursos financeiros decorrentes de suas atividades oriundos de diversas fontes, dentre elas ${ }^{36}$ :

(i) contribuições da BM\&FBOVESPA, seu associado mantenedor;

35 Relatório das Atividades da BSM em 2011, disponível para consulta em http://www.bovespasupervisaomercado.com.br/InstDownload/Relatorio-de-Atividades-2011.pdf 36 Artigo $7^{\circ}$ do Estatuto Social da BSM, disponível para consulta em http://www.bovespasupervisaomercado.com.br/InstDownload/BSM-Estatuto-Social.pdf 
(ii) taxa referente à administração do $\mathrm{MRP}$, nos termos da regulamentação estabelecida pela CVM; e

(iii) taxas relacionadas às atividades de supervisão, fiscalização, auditoria, suporte operacional e administrativo e outros serviços.

Nesse particular, salientamos que além da independência orçamentária, a BSM ainda possui personalidade jurídica e patrimônio próprios, autoridade administrativa independente, ausência de subordinação hierárquica (atentamos para o fato, como já mencionado acima, da CVM ter o poder legal de supervisionar as atividades desempenhadas pela BSM), mandato fixo e estabilidade do Diretor de Autorregulação e dos membros do Conselho de Supervisão.

Portanto, e como se pode extrair do presente trabalho monográfico após exaustiva análise, a BSM não possui competência para julgar atos ilícitos praticados, por exemplo, por investidores nos mercados da BM\&FBOVESPA, tendo, por outro lado, o dever de comunicar às autoridades competentes (i.e. CVM e BCB) caso verifique a incidência dos mesmos.

\subsection{A Administração da BSM}

A administração da BSM compete, como disposto no artigo 25 de seu Estatuto Social, ao Diretor de Autorregulação. Para tanto, deverá o eleito para o cargo, preliminarmente, ser isento dos impedimentos relativos à inelegibilidade para cargos de administração de companhias previstas na legislação societária, bem como de condenação transitada em julgado por crime contra o mercado financeiro ou de capitais. Ainda, deverá ser 
residente e domiciliado no Brasil e possuir ilibada reputação e reconhecida competência em matéria de mercado de capitais.

No mister de suas atribuições, cabe, privativamente, ao Diretor de Autorregulação, segundo o artigo 28 do Estatuto Social da BSM:

(i) dar execução à política e às determinações do Conselho de Supervisão, bem como dirigir todos os trabalhos da BSM;

(ii) praticar os atos necessários ao funcionamento da BSM;

(iii) contratar ou demitir os integrantes do quadro de executivos da BSM, determinando-lhes as atribuições e poderes;

(iv) representar, ativa e passivamente, a BSM, cabendo-lhe, ainda, constituir mandatários com poderes gerais e especiais determinados e com prazo de validade, excetuadas as procurações outorgadas para fins judiciais;

(v) prestar informações de caráter sigiloso, envolvendo nomes, operações e serviços prestados, quando requeridas pela CVM ou pelas autoridades e entidades autorizadas em lei a ter acesso a essas informações;

(vi) submeter à aprovação do Conselho de Supervisão:

(a) proposta orçamentária e o programa anual de trabalho para o exercício subsequente;

(b) relatório anual de prestação de contas das atividades realizadas pela BSM, devidamente auditado pelo auditor independente, indicando os principais responsáveis por cada uma delas, bem como as medidas adotadas ou recomendadas em decorrência de sua atuação; 
(c) proposta de código de conduta aplicável a todos os empregados da BSM, aos integrantes do Conselho de Supervisão e ao próprio Diretor de Autorregulação;

(d) proposta relativa aos valores das contribuições do Associado Mantenedor e das contribuições e taxas a serem cobradas das pessoas ou entidades para as quais a BSM provê suporte administrativo ou operacional, ou preste serviços, ou que estejam a ela submetidas, observados os parâmetros de mercado e respectivos níveis mínimos de capitalização, investimento e remuneração necessários à BSM;

(e) relatório descritivo sobre a inobservância das normas legais, regulamentares e operacionais, aplicáveis aos mercados administrados por seu Associado Mantenedor e os desvios observados nas operações, mencionado as análises iniciadas e concluídas no período, com a indicação dos comitentes envolvidos, bem como das providências adotadas;

(f) relatório sobre as auditorias concluídas no período, mencionando as pessoas autorizadas a operar que foram inspecionadas, o escopo do trabalho realizado, o período abrangido, o resultado final, as irregularidades identificadas e as providências adotadas; e

(g) relatório com a enumeração dos processos administrativos instaurados, inclusive aqueles relativos ao uso do MRP, com identificação das pessoas interessadas e respectivas condutas.

(vii) promover a fiscalização direta e ampla dos Participantes;

(viii) promover a fiscalização das operações realizadas na BM\&FBOVESPA relacionadas às atividades desempenhadas pela BSM;

(ix) remeter:

(a) mensalmente à CVM os balancetes do MRP e os relatórios analíticos e de auditoria elaborados por determinação da CVM;

(b) mensalmente aos Associados os balancetes da BSM e do MRP; e 
(c) anualmente à CVM e aos Associados os respectivos relatórios da administração e as demonstrações financeiras do exercício, tanto da BSM como do MRP.

(x) propor fundamentadamente à BM\&FBOVESPA que suspenda a negociação de qualquer ativo, título ou valor mobiliário nela negociado;

(xi) determinar fundamentadamente à BM\&FBOVESPA o cancelamento de negócio nela realizado;

(xii) determinar fundamentadamente a suspensão da liquidação de operação realizada na BM\&FBOVESPA;

(xiii) determinar a apuração das infrações às normas cujo cumprimento incumbe à BSM supervisionar, fiscalizar ou auditar;

(xiv) determinar a aplicação das penalidades previstas no artigo $30^{37}$ do Estatuto Social da BSM nos casos de infração objetiva $^{38}$ às normas regulamentares e operacionais da BM\&FBOVESPA, e da própria BSM, assim como nos casos de:

(a) descumprimento a determinações da BM\&FBOVESPA; e

(b) infração de natureza objetiva conforme definida em norma específica.

\footnotetext{
${ }^{37}$ O artigo 30 do Estatuto Social da BSM prevê: "Art. 30 - As penalidades que podem ser aplicadas pela BSM são: I - advertência; II - multa; III - suspensão, observado o prazo máximo de noventa dias; $I V$ - inabilitação temporária, pelo prazo máximo de dez anos, para o exercício de cargos de administradores, empregados, operadores, prepostos e representantes da própria BSM, do Associado Mantenedor e dos Participantes; e V-outras penalidades previstas nas normas regulamentares e operacionais da própria BM\&FBOVESPA".

${ }^{38}$ Cumpre ressaltar que a restrição às infrações de natureza objetiva foi ponto de discussão no âmbito do Processo CVM SP 2011/0253, onde o Colegiado da CVM se pronunciou no sentido de que o "Diretor de Autorregulação passa a ser competente para aplicar todas as penas previstas no Estatuto Social da BSM e no seu Regulamento Processual (atualmente somente podem ser aplicadas pelo Diretor as penas de advertência e multa), desde que a infração cometida seja objetiva." (grifos nossos)
} 
(xv) enviar à CVM, tempestivamente, todos os documentos e informações exigidos em normativos emitidos pela referida autarquia ou pelo Conselho Monetário Nacional;

(xvi) submeter à aprovação da assembleia geral da BSM, com seu parecer, o relatório e as demonstrações financeiras ao término de cada exercício social;

(xvii) fiscalizar o cumprimento das obrigações assumidas em termo de compromisso;

(xviii) traçar a política geral da BSM e zelar por sua boa execução;

(xix) avaliar e monitorar a gestão de riscos da BSM; e

(xx) aprovar a estrutura organizacional da BSM, definindo cargos, funções e a política de remuneração.

Como se pode notar, o Diretor de Autorregulação da BSM possui um rol extenso de atribuições (reproduzindo amplamente as disposições da Instrução CVM 461), fato que, por óbvio, lhe restringe apenas ao exercício daquela diretoria, não podendo exercer qualquer outro cargo em outra sociedade, salvo o exercício do magistério, caso haja compatibilidade de horário.

Nesse particular, nota-se que incumbe ao Diretor de Autorregulação, concomitantemente, a aplicação das penalidades previstas no artigo 30 do Estatuto Social da BSM, e, conforme dispõe o artigo $2^{\circ}$ do Regulamento Processual da BSM, a instauração de sindicâncias ou inquéritos administrativos para apurar a prática de infrações às normas cujo cumprimento a BSM está incumbida de supervisionar, fiscalizar ou auditar. 
Por uma questão claramente jurídica (uma vez que se trataria de um retrocesso, em um estado moderno de direito, a outorga de poderes acusatórios e julgadores para uma mesma pessoa), esse direito de acusação / julgamento não é absoluto, uma vez que não poderia a entidade autorreguladora valer-se de um Sistema Acusatório (como se viu na época da Inquisição, onde "a confissão era a rainha das provas") para condução de seus trabalhos.

Tal como em um Sistema Inquisitivo, onde os princípios do livre convencimento e as pessoas que acusam e julgam são distintas, não cabe ao Diretor de Autorregulação (como inicialmente o Estatuto Social da BSM instituiu) o julgamento de todos os processos administrativos em trâmite perante a BSM, mas tão somente aqueles de rito sumário (precipuamente aqueles que possuam natureza infratora objetiva à norma regulamentar), quais sejam as hipóteses ${ }^{39}$ :

(i) infrações de natureza objetiva, conforme definida em norma da CVM;

(ii) infração objetiva às normas regulamentares e operacionais da BSM, da BM\&FBOVESPA, da BVSP ou da CBLC;

(iii) não atendimento, ou não cumprimento, no prazo e forma estabelecidos, de solicitação ou de determinação da BSM, BM\&FBOVESPA, BVSP, ou CBLC;

(iv) cessão indevida ou uso indevido de senha de acesso aos sistemas da BM\&FBOVESP A, da BVSP e da CBLC por administradores, empregados, operadores, administradores ou

\footnotetext{
${ }^{39}$ Artigo 28 do Regulamento Processual da BSM.
} 
prepostos de Participante ou Agente.

Com efeito, da decisão proferida pelo Diretor de Autorregulação será dado conhecimento por escrito ao acusado para, querendo, em petição encaminhada ao mesmo, recorrer ao Conselho de Supervisão, no prazo de 15 dias, a contar da ciência da decisão. Nesse caso (i.e., interposição de recurso), é obrigatória a presença do Diretor de Autorregulação na reunião. Não sendo interposto recurso, a decisão do Diretor de Autorregulação transitará em julgado, passando a ser definitiva na esfera administrativa.

Por fim, e como veremos adiante, o julgamento dos processos administrativos na BSM de natureza ordinária é de competência privativa do Conselho de Supervisão, cabendo ao Diretor de Autorregulação apenas a instauração (mediante Termo de Acusação) e a condução da etapa de Instrução (i.e., produção de provas, solicitação de diligências adicionais, dentre outros).

\subsection{O Conselho de Supervisão da BSM}

O Conselho de Supervisão é o órgão de deliberação colegiada da BSM e foi inspirado na figura do Conselho de Autorregulação prevista no artigo 36 da Instrução CVM 461. Segundo seu regimento interno, compete privativamente ao Conselho de Supervisão exercer as seguintes atribuições, além daquelas, ou em conjunto com, previstas no Estatuto Social da BSM:

(i) determinar a aplicação de penalidades aos Associados, membros do Conselho de Administração, membros do Conselho de Supervisão e ao Diretor de Autorregulação;

(ii) julgar recurso contra penalidade aplicada pelo Diretor de Autorregulação; 
(iii) julgar recurso contra penalidade aplicada pela $\mathrm{BM} \& \mathrm{FBOVESPA}$ ou pela $\mathrm{CBLC}$, inclusive àquelas de caráter operacional;

(iv) julgar recurso contra decisão da BM\&FBOVESPA que tenha determinado a suspensão de negociação de título ou valor mobiliário;

(v) julgar recurso contra a decisão da CBLC que tenha determinado a suspensão da liquidação de operação realizada na BM\&FBOVESPA;

(vi) julgar recurso contra decisão da BM\&FBOVESPA e da CBLC que tenha determinado a exclusão de emissor de valor mobiliário, participante ou agente;

(vii) julgar reclamação formulada por investidor dirigida ao MRP, cabendo recurso à CVM;

(viii) elaborar e aprovar seu próprio Regimento Interno;

(ix) eleger, dentre os conselheiros independentes, seu Presidente, a quem competirá a condução dos trabalhos administrativos do órgão e representá-lo perante a CVM;

(x) aprovar a celebração de Termo de Compromisso proposto por envolvido em inquérito ou processo administrativo e fiscalizar seu cumprimento; e

(xi) determinar ao Diretor de Autorregulação da BSM e ao Diretor Geral da BM\&FBOVESPA ou da CBLC a aplicação das 
penalidades que impuser ou decorrentes dos recursos que julgar, acompanhando sua execução.

$\mathrm{Na}$ aplicação de penalidades e no julgamento de recursos ou de reclamações, o Conselho de Supervisão deverá obrigatoriamente observar o disposto nos seguintes regulamentos da BSM: (i) Regulamento Processual, quando se tratar de aplicação de penalidades e julgamento de recursos; e (ii) Regulamento do MRP, quando se tratar de reclamação dirigida por investidor ao MRP.

O Conselho de Supervisão é composto, atualmente, por 12 membros (dentre eles o Diretor de Autorregulação, o qual não possui direito de voto), possuindo um presidente. O mandato como membro ordinário do Conselho de Supervisão será de três anos, admitindo-se a reeleição, ao passo que o mandato como Presidente ${ }^{40}$ do Conselho de Supervisão será de um ano, admitida uma única reeleição (tal eleição dar-se-á pelos membros do Conselho de Supervisão na primeira reunião após a eleição dos membros em assembleia).

Ainda, e segundo o artigo 16, inciso I, do Estatuto Social da BSM, compete privativamente à assembleia geral a eleição e destituição dos membros do Conselho de Supervisão.

O Conselho de Supervisão deverá se reunir, em turma ou em pleno,

\footnotetext{
${ }^{40}$ Segundo regimento interno do Conselho de Supervisão da BSM compete ao Presidente do Conselho de Supervisão: (i) assegurar a eficácia e o bom desempenho do órgão; (ii) organizar e coordenar a pauta das reuniões; (iii) convocar e presidir as reuniões do Conselho de Supervisão, com voto de qualidade em caso de empate; (iv) convidar pessoas para comparecimento às reuniões do Conselho de Supervisão para prestarem informações e/ou esclarecimentos; (v) solicitar a emissão de parecer por consultor especializado, quando se tratar de assunto complexo ou controverso. Caso o parecer represente ônus financeiro para a BSM, sua emissão está condicionada à prévia aprovação do Conselho de Administração; (vi) zelar, em conjunto com os demais membros, pela execução das deliberações do Conselho de Supervisão; (vii) propor, no início de cada exercício, o calendário anual de reuniões ordinárias do Conselho de Supervisão; (viii) proceder a sorteio para a constituição de Turma destinada à aplicação de penalidades, julgamento de recursos e julgamento de reclamação de investidor dirigida ao Mecanismo de Ressarcimento de Prejuízos, bem como, quando for o caso, para a designação de Relator e Revisor.
} 
preferencialmente uma vez por mês, na sede da BSM, mediante convocação do presidente para: (i) aplicar penalidades; (ii) julgar recursos contra penalidades aplicadas; (iii) julgar reclamação de investidor dirigida ao MRP; e (iv) aprovar a celebração de Termo de Compromisso. Ainda, as turmas reunir-se-ão sempre que houver necessidade, independentemente das reuniões plenárias, mediante convocação de seus coordenadores. Para a discussão de matéria relevante e urgente, o Conselho de Supervisão reunirse-á extraordinariamente por convocação de seu presidente.

Quanto ao caráter julgador do Conselho de Supervisão da BSM, o artigo 25 do Regulamento Processual da BSM dispõe que, exceto pelas hipóteses de rito sumário (melhores descritas acima), os processos administrativos sob rito ordinário serão julgados, em primeira instância, pelo Conselho de Supervisão. Tal julgamento em primeira instância deverá ser realizado por meio de turma composta por três membros, mediante sorteio dentre todos os membros.

Em se tratando de processo envolvendo associado, seus administradores, empregados e prepostos, ou o próprio Diretor de Autorregulação, será criada turma especial composta pelo presidente do Conselho de Supervisão e pelos dois integrantes desse órgão que sejam também membros do Conselho de Administração da BSM.

Por fim, o Conselho de Supervisão julgará em segunda instância: (i) os recursos interpostos contra decisão de turma; (ii) os recursos interpostos contra decisão: (a) do Diretor de Autorregulação da BSM, (b) do Diretor Presidente da BM\&FBOVESPA, (c) do Diretor Geral da BM\&FBOVESPA e (d) do Diretor Geral da CBLC; e (iii) decisão do Diretor de Autorregulação aceitando o arquivamento do inquérito administrativo. 
Importa ressaltar que, da decisão proferida pelo pleno do Conselho de Supervisão em segunda instância, não caberá recurso ao participante do mercado, consistindo a mesma em decisão final na esfera administrativa.

Diante disso, apresentamos abaixo, de forma esquematizada, a competência do Conselho de Supervisão quanto ao julgamento de processos administrativos no âmbito da BSM:

Competência Julgadora dos Processos Administrativos em sede de $\underline{\text { BSM }}$

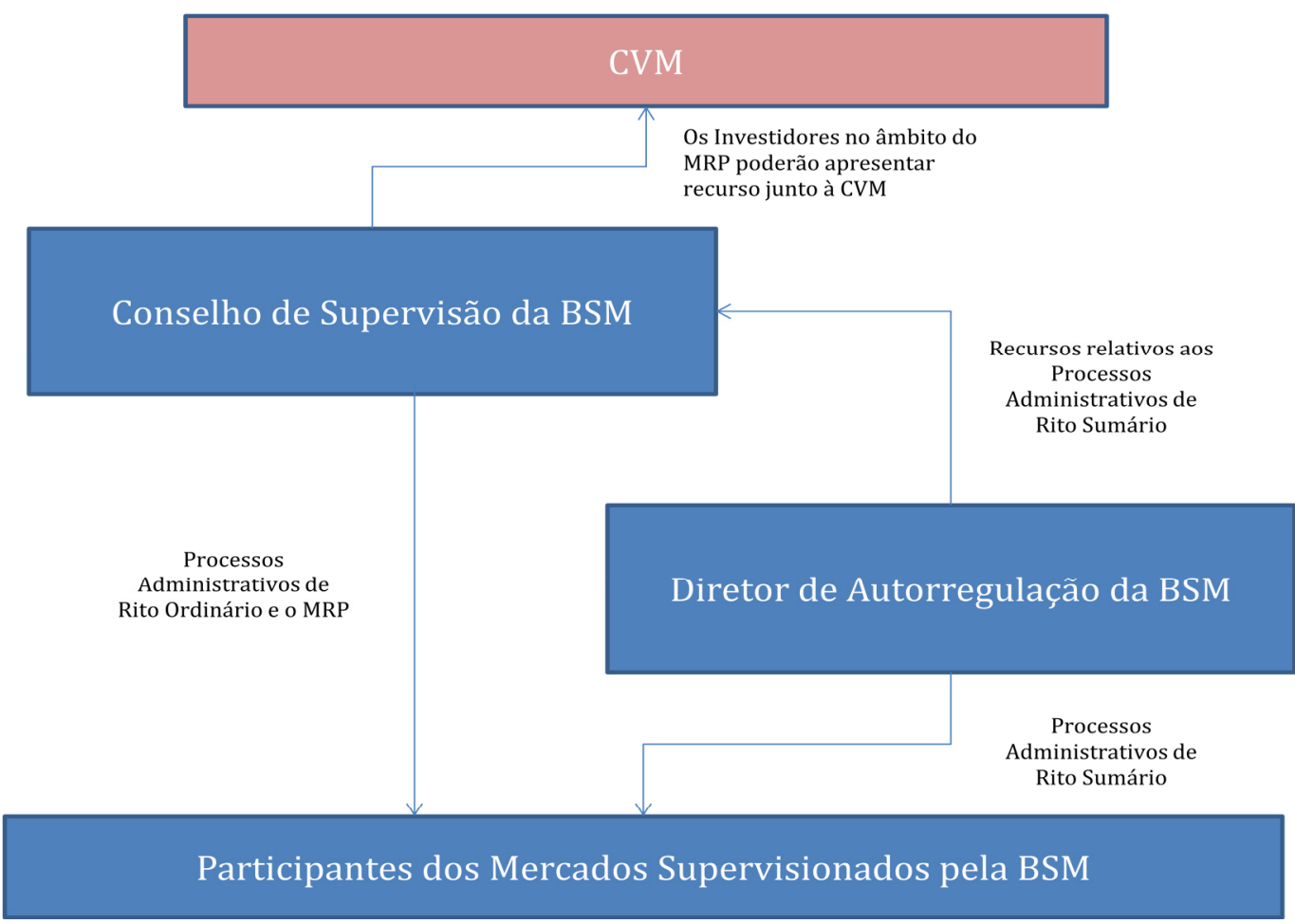




\section{Capítulo 5. Formas de proteção ao investidor e o atual "Mecanismo de Ressarcimento de Prejuízos - MRP"}

\subsection{A Criação do "Fundo de Garantia das Bolsas de Valores" e suas Principais Características}

A criação de um fundo de garantia das bolsas de valores como forma de proteção ao investidor e seus associados se deu por meio da edição da Resolução CMN 39, a qual disciplinava a constituição, organização e funcionamento das bolsas de valores no Brasil.

Pode se notar, até então, que o principal sujeito das operações bursáteis - o investidor - que vislumbrasse irregularidades a ele acometidas por participantes das bolsas de valores não possuía o direito de ser ressarcido, ficando, na linguagem popular e com toda vênia, literalmente " $a$ ver navios". Com efeito, o único instituto que poderia amparar os investidores nesses casos era a justiça comum, que, como já sabemos, é notável pela sua morosidade. Restava aos investidores, portanto, esperar décadas para se verem ressarcidos de um ato ilícito que, muitas vezes, ocorria em uma fração de segundos.

Foi nessa conjuntura de insegurança que o Conselho Monetário Nacional decidiu instituir, como forma de estimular a entrada de investidores no mercado de capitais pátrio, o fundo de garantia das bolsas de valores, de modo que não houvesse um fator limitador que definhasse a evolução do sistema de valores mobiliários no Brasil.

Como bem tratou o Parecer/CVM/SJU/ $n^{\circ} 22$, de 31 de janeiro de 1979, o artigo 45 da Resolução CMN 39 era visto como "uma técnica de indenizar o risco do investidor que exceda o risco normal dos negócios em 
Bolsa, e destas como um serviço de interesse público de preservar a liquidez do mercado".

Nesse sentido, o artigo 45 da Resolução CMN 39 instituía que "As Bolsas de Valores manterão um Fundo de Garantia com a finalidade exclusiva de assegurar aos clientes de seus associados, até o limite do referido Fundo, a reposição de títulos e valores mobiliários negociados em Bolsa e a devolução de diferenças de preços decorrentes de dano culposo ou de infiel execução de ordens aceitas para cumprimento em Bolsa, de responsabilidade caracterizada no art. 25, ou ainda de uso inadequado de importâncias recebidas para compra ou decorrentes da venda de títulos e valores mobiliários".

Por outro lado, seu artigo 25 dispunha que os membros das bolsas de valores seriam responsáveis:

(i) nas operações à vista, para com seu comitente e para com outros membros das bolsas de valores com quem hajam operado:

(a) pela entrega dos títulos e valores mobiliários vendidos e pelo pagamento dos comprados;

(b) pela legitimidade dos títulos ou valores mobiliários entregues; $\mathrm{e}$

(c) pela autenticidade dos endossos.

(ii) nas operações a termo, por sua liquidação até o registro dos contratos respectivos no órgão competente. 
Primeiramente, há que se colocar que o referido fundo seria constituído de um patrimônio alheio a quaisquer fundos, bens, reservas ou provisões das bolsas de valores, sendo composto, portanto, por (i) $25 \%$ das importâncias pagas às bolsas de valores pela aquisição de títulos patrimoniais de sua emissão; e (ii) taxa a ser cobrada dos associados das bolsas de valores, independentemente de quaisquer outras que existam ou venham a existir, e equivalente a $1 \%$ das corretagens por eles recebidas, taxa essa que poderia ser elevada, em caráter permanente ou temporário, por decisão do conselho de administração das bolsas de valores e aprovada pelo BCB.

Nesse sentido, cumpre enfatizar que a bolsa de valores e o fundo de garantia por ela administrado possuíam patrimônios distintos, que não se confundiriam, tampouco se contaminariam, constituindo-se esse último, portanto, em um patrimônio de afetacão ${ }^{41}$. Cumpre conceituar que o patrimônio de afetação consiste em determinada massa patrimonial independente, isto é, que não se confunde com a massa patrimonial da pessoa que o mantém, cujo objetivo residiria, principalmente, no cumprimento de determinadas finalidades.

Indo mais além, e tomando emprestado o conceito da Lei $\mathrm{n}^{\circ} 10.931$, de 2 de agosto de 2004, conforme alterada, que trata do patrimônio de afetação de incorporações imobiliárias, letras de crédito imobiliário, cédulas de crédito bancário, dentre outros, diz-se que o patrimônio de afetação " $\underline{n a \tilde{o}}$ se comunica com os demais bens, direitos e obrigações do patrimônio geral do incorporador ou de outros patrimônios de afetação por ele constituídos e só responde por dívidas e obrigações vinculadas à incorporação respectiva.”(g.n).

\footnotetext{
${ }^{41}$ EIZIRIK, Nelson et al.. Mercado de Capitais Regime Jurídico. $2^{\mathrm{a}}$ ed. Rio de Janeiro: Renovar, 2008. 224 p.
} 
Diante do cristalino conceito previsto no referido diploma legal, temse que o patrimônio de afetação, ou, como bem citou Nelson Eizirik, essa massa patrimonial independente, se mantém indistinta e definitivamente afastada do patrimônio geral do ente a que se vincula, não podendo ser utilizado de maneira contrária à sua finalidade e, geralmente, são reservados em favor de certo grupo de credores ${ }^{42}$. No caso específico dos fundos de garantia das bolsas de valores, dizemos que o grupo de credores cuja justificativa originou a segregação patrimonial são os investidores potencial e indistintamente "lesáveis".

Outra característica dos fundos de garantia das bolsas de valores era a de que as devoluções e reposições aos clientes e associados seriam efetuadas pelo fundo em que se encontrar registrada a sede ou dependência da firma ou sociedade corretora que receber a ordem do cliente.

Ponto interessante da estrutura dos antigos fundos de garantia das bolsas de valores era o de que, no mínimo, 50\%, do patrimônio do fundo deveria ser investido em títulos de renda fixa, com ou sem correção monetária, e o restante em ações de sociedades anônimas de capital aberto, respeitados os critérios de diversificação adotados para os fundos de investimento, sendo certo que o produto da correção monetária e dos rendimentos decorrentes de tais aplicações se incorporariam automaticamente ao patrimônio do fundo de garantia.

Quanto à direção dos fundos de garantia, a redação original do artigo 50 da Resolução CMN 39 instituía que deveria ser realizada por comissão especial constituída pelo superintendente geral e por dois integrantes do conselho de administração das bolsas de valores, designados por tal órgão anualmente.

\footnotetext{
${ }^{42}$ EIZIRIK, Nelson et al.. Mercado de Capitais Regime Jurídico. $2^{\mathrm{a}}$ ed. Rio de Janeiro: Renovar, 2008. 224 p.
} 
Ainda, e conforme artigo 54 da Resolução CMN 39, as bolsas de valores deveriam manter, permanentemente, seguro específico por conta do fundo de garantia de forma a segurar a reposição das importâncias pagas.

Como resultado de diversas revogações e alterações, o fundo de garantia das bolsas de valores é previsto hoje no artigo 40 da Resolução $\mathrm{BCB} \mathrm{n}^{\circ} 2.690$, diploma regulamentar notavelmente mais robusto e maduro, consequência do inquestionável amadurecimento do mercado de valores mobiliários pátrio durante, aproximadamente, três décadas. Segundo essa resolução, possui o fundo de garantia a finalidade exclusiva de assegurar aos investidores do mercado de valores mobiliários, até o limite do fundo ${ }^{43}$, o ressarcimento de prejuízos decorrentes da atuação de administradores, empregados ou prepostos de sociedade membro ou permissionária, em relação à intermediação de negociações realizadas em bolsa e aos serviços de custódia.

Nessa linha, o referido artigo dispõe, de maneira incisiva, as hipóteses por meio das quais os investidores poderão requerer o seu ressarcimento, verbis:

"I - inexecução ou infiel execução de ordens;

II - uso inadequado de numerário, de títulos ou de valores mobiliários, inclusive em relação a operações de financiamento ou de empréstimos de ações para a compra ou venda em bolsa (conta margem);

III - entrega ao investidor de títulos ou valores mobiliários ilegítimos ou de circulação proibida; (NR);

IV - inautenticidade de endosso em título ou em valor mobiliário ou ilegitimidade

${ }^{43}$ Cumpre frisar que, como não há qualquer previsão expressa de valores máximos para o ressarcimento, as perdas com eventos passíveis de gerar reclamação ao fundo são, atualmente, integralmente indenizadas. 
de procuração ou documento necessário à transferência dos mesmos;

$V$ - decretação de liquidação extrajudicial pelo Banco Central do Brasil; e

VI - encerramento das atividades.”

Não obstante, e como já dito, o ressarcimento de prejuízos aos investidores no âmbito da BM\&FBOVESPA atualmente é feito única e exclusivamente por meio do MRP, mantido e administrado pela BSM, modalidade essa que difere do fundo de garantia das bolsas de valores e possui regulamentação própria expedida pela CVM (i.e. Instrução CVM $461)$.

Veremos mais a frente, igualmente, que a Instrução CVM 461 - e porque não dizer o próprio mecanismo de ressarcimento de prejuízos ali inserido - possui diversos dispositivos mais benéficos ao investidor do que aqueles previstos na Resolução BCB $n^{\circ} 2.690$ (tal como o prazo mais extenso para apresentação da reclamação, dentre outros).

\subsection{O MRP como nova modalidade de proteção ao investidor e a Instrução CVM 461}

"A corretora falhou na execução de uma ordem de compra. O que posso fazer?"

Muitos brasileiros inseridos na nova realidade dos investimentos e manutenção de uma poupança para sua aposentadoria já podem ter se deparado com esse questionamento. O súbito aumento do número de clientes das sociedades corretoras ocasionou um descompasso - muitas vezes nefasto - entre a solicitação para execução de uma ordem de compra 
ou venda em ambiente bursátil e a própria prestação razoável dos serviços de intermediação de recursos.

Como em toda prestação indevida de serviços - ou a sua própria ausência -, o primeiro passo para o investidor, na qualidade de cliente, seria procurar a instituiçãa ou o serviço de atendimento ao cliente para solicitar esclarecimentos e resolução do problema. Em muitos casos, a questão não é superada pela autocomposição, ensejando a propositura de uma ação na esfera judicial na esperança - vã, em muitos casos - do lesado se ver ressarcido de seus prejuízos. Como é sabido, a solução de conflitos na esfera judicial pode ser extremamente morosa, o que pode ocasionar ao investidor danos absolutamente irreparáveis.

Diante de todos esses impasses surge a figura de um mecanismo privado de solução de controvérsias para a proteção ao investidor cujo objetivo é o de repará-lo, da maneira mais célere possível, em casos de desvios (ou em outras hipóteses) cometidos pelas sociedades corretoras: o MRP. Tal mecanismo foi criado para ser flexível, assemelhando-se - em parte - às soluções de controvérsias patrocinadas pelo Estado no âmbito da esfera judicial.

Nesse sentido foi o voto da Ilma. Diretora da CVM Luciana Dias que, no âmbito do Processo Administrativo CVM n SP2007/0051, resumiu as características que mencionamos acima, senão vejamos:

“o mecanismo de ressarcimento de prejuízos é um mecanismo privado de solução de controvérsias. Assim, embora muito de sua sistemática se assemelhe às soluções de controvérsia patrocinadas pelo Estado, ele não está adstrito a todos os princípios e regras do processo civil porque foi "arquitetado para ser flexível e ressarcir, de maneira célere, prejuízos causados por falhas operacionais, cujos reclamantes nem sempre são assistidos por advogados, e, por isso, não necessariamente está adstrito aos rígidos padrões de aplicação das regras 
processuais civis e administrativas."

Podemos dizer que o MRP é um instrumento de indenização que assegura aos investidores em geral o ressarcimento de prejuízos decorrentes de erros operacionais das sociedades corretoras na intermediação de operações realizadas em ambiente bursátil, na prestação de serviços de custódia ou, até mesmo, em caso de encerramento das atividades de uma sociedade corretora, independente da adoção das medidas judiciais eventualmente cabíveis. Indo mais além, o MRP seria um "seguro" destinado a todos os investidores, sem qualquer grau de qualificação, contra atitudes arbitrárias de sociedades corretoras que, até certo momento no cenário brasileiro, eram realizadas com intensa repetição.

Portanto, mecanismos de ressarcimento tal como o MRP visam a contribuir para a confiabilidade dos investidores e a integridade do sistema de negociação de valores mobiliários, tendo sido desenvolvido com base nos fundos ou seguros garantidores de depósito (e.g. o Fundo Garantidor de Crédito) de modo a minimizar hipóteses de crises de confiança no mercado, sobretudo no que tange à insegurança de pequenos investidores.

Apenas para demonstrar a importância do MRP, precipuamente em tempos de crise econômica, apresentamos abaixo gráfico ${ }^{44}$ contendo a quantidade de reclamações ao MRP desde o período de 2005 até o ano de 2011. Como se poderá notar da curva de crescimento abaixo, houve um período de stress significativo a partir de 2008, fato que atesta a importância do MRP junto aos investidores em tempos de crise:

\footnotetext{
${ }^{44}$ Fonte: http://www.bovespasupervisaomercado.com.br/InstDownload/Relatorio-de-Atividades2011.pdf.
} 


\section{Quantidade de reclamações ao MRP}

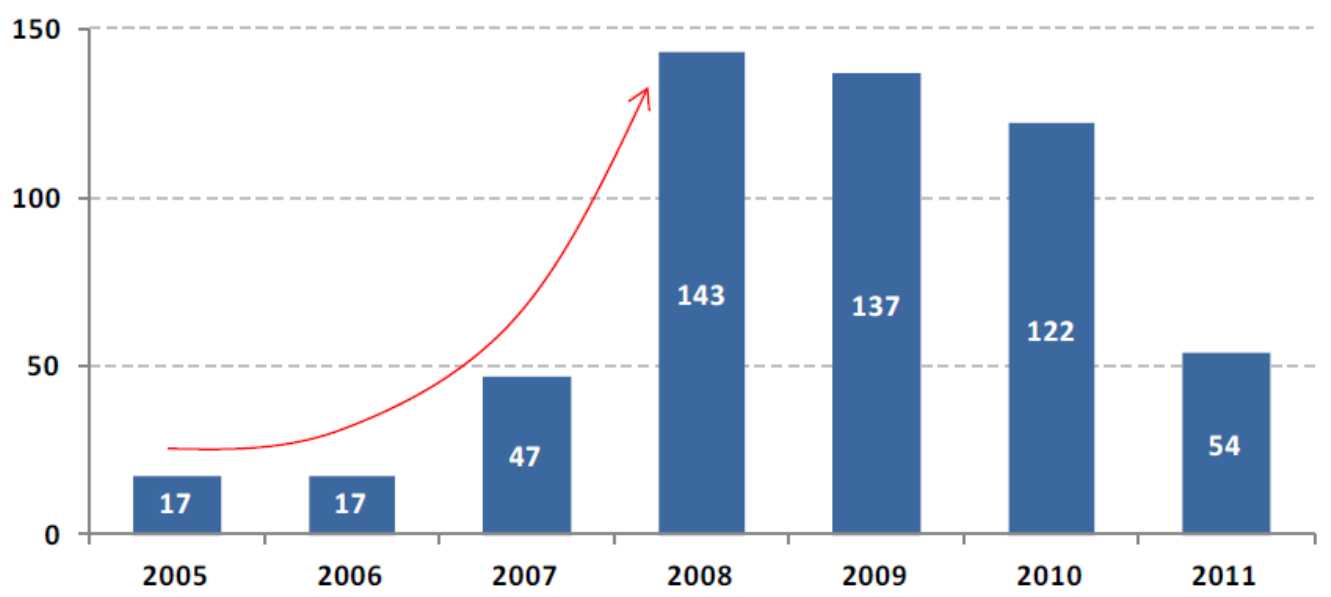

O MRP teria, então, um caráter relativamente semelhante ao fundo de garantia das bolsas de valores, ou seja, de um patrimônio de reparação aos investidores, mas que, como dispõe a Instrução CVM 461, poderia ser constituído tanto sob a forma de um fundo ou como, por exemplo, pela contratação de um seguro. O fundo de garantia das bolsas de valores, por outro lado, somente poderia ser constituído sob a forma específica de um fundo em dinheiro, cujo patrimônio, como dito acima, seria formado preponderantemente por contribuições dos sócios das bolsas de valores.

Como bem dispôs a Instrução CVM 461, em seu artigo 78, a entidade administradora de mercado de bolsa deve baixar regulamento específico disciplinando o funcionamento do mecanismo de ressarcimento de prejuízos, ficando o normativo da CVM apenas incumbido de outorgar diretrizes mínimas à constituição do mecanismo de ressarcimento de prejuízos $^{45}$.Vê-se que o intuito da CVM foi deixar a critério das bolsas de

\footnotetext{
${ }^{45}$ Segundo o artigo 78 da Instrução CVM 461, o regulamento do mecanismo de ressarcimento de prejuízos a ser baixado pela entidade administradora deverá conter, no mínimo, as seguintes disposições "I - descrição da forma de organização e designação de seus administradores, quando couber; II - descrição detalhada da forma de indenização aos reclamantes, dos prazos de pagamento e da forma de correção dos valores; III - procedimentos e prazos para análise dos pedidos de indenização, que não podem exceder 120 (cento e vinte) dias entre o pedido de indenização e a decisão da bolsa a respeito; IV - as instâncias responsáveis pela condução do processo e pela decisão final; V-origem dos recursos; VI - valores mínimo e máximo do patrimônio ou montantes mínimo e máximo alocados para o mecanismo de ressarcimento de prejuízos, os quais devem ser fundamentados na análise dos riscos inerentes à sua atividade, bem
} 
valores as características específicas de seus mecanismos de ressarcimento de prejuízos.

Outro ponto importante e benéfico da nova regulamentação dos mecanismos de ressarcimento de prejuízos foi o fato da CVM estender o prazo para o investidor pleitear o ressarcimento de seu prejuízo, para $\underline{18}$ meses contados da data de ocorrência da ação ou omissão que tenha dado origem ao pedido, prazo esse que, no caso do fundo de garantia das bolsas de valores, seria de seis meses. Nesse particular, cabe ressaltar que a Resolução BCB $n^{\circ}$ 2.690, que trata do fundo de garantia das bolsas de valores, dispõe em seu artigo 41 , parágrafo $2^{\circ}$, que quando o investidor não tiver tido a possibilidade de acesso a elementos que lhe permitam tomar ciência do prejuízo, o prazo de seis meses será contado a partir do conhecimento do fato. Por uma opção que, desde já, discordamos, a CVM optou $^{46}$, se por um lado por estender o prazo para 18 meses, por não fazer essa distinção (i.e., contagem do prazo a partir do conhecimento do investidor), de forma que o investidor terá 18 meses, a partir do evento que $\underline{\text { motive o ressarcimento do prejuízo, para apresentar a reclamação junto ao }}$ $\underline{\text { MRP, independente da data de ciência por parte do interessado. }}$

Quanto ao valor máximo proporcionado pelos recursos do MRP em caso de ressarcimento, a Instrução CVM 461 instituiu, originalmente, o montante de $\mathrm{R} \$ 60.000,00$ por investidor reclamante, sem prejuízo de fixação voluntária, pelas bolsas de valores, de quantias superiores.

como os critérios de rateio em caso de insuficiência do patrimônio; VII - política de aplicação dos recursos do mecanismo de ressarcimento de prejuízos; e VIII - forma e prazo de reposição ao mecanismo, pela pessoa autorizada a operar que deu causa à reclamação, do valor pago ao reclamante, bem como a penalidade prevista pelo descumprimento desta obrigação."

${ }^{46}$ Segundo o entendimento da CVM no âmbito da Audiência Pública n ${ }^{\circ}$ 06/2007, de 28 de junho de 2007, que culminou na Instrução CVM 461, "o prazo de 18 (dezoito) meses correrá, independentemente da ciência do interessado, a partir da ocorrência do evento que motive o pedido de ressarcimento. Esse prazo foi escolhido no pressuposto de que, ao menos uma vez por ano, ao preparar sua declaração de renda, o investidor procura documentos dos quais conste sua posição acionária atualizada, e tem a oportunidade de compará-la com a do exercício anterior." 
Curiosamente, a CVM optou por alinhar o valor máximo do ressarcimento de prejuízos ao valor adotado pela Resolução do BCB $\mathrm{n}^{\circ}$ 3.400 , de 6 de setembro de $2006^{47}$, a qual instituía as normas sobre o Fundo Garantidor de Créditos ("FGC") e dispunha que o total de créditos contra uma instituição financeira seria garantido no valor de $\mathrm{R} \$ 60.000,00$. Atualmente, e por meio da edição da Instrução CVM n ${ }^{\circ} 499$, de 13 de julho de 2011, o valor máximo por investidor reclamante no âmbito do mecanismo de ressarcimento de prejuízos foi majorado para $\underline{\mathbf{R} \mathbf{\$ 7 0 . 0 0 0 , 0 0}}$.

Nesse particular, cumpre salientar que a razão para existência de um limite para o ressarcimento não está relacionado à pretensão de recebimento do investidor, mas sim ao nível de ressarcimento suficiente para evitar uma crise de confianca dos pequenos investidores. Assim, o objetivo do mecanismo de ressarcimento não é resolver integralmente pretensões de recebimento dos investidores, por mais legítimas que sejam, e sim preservar a higidez do sistema e a confiança do investidor em tal sistema ${ }^{48}$.

O mecanismo de ressarcimento de prejuízos não é - nem poderia ser -, portanto, medicamento para controvérsias de qualquer natureza surgidas entre sociedades corretoras e seus clientes-investidores, servindo para dar cabo a situações que possam colocar em jogo a rigidez, estrutura e confiabilidade dos mercados em geral. Por óbvio, outros tipos de disputas (que não as previstas no MRP) deverão ser dirimidas, como já dito acima, pelos mecanismos tradicionais de solução de conflitos, isto é, as esferas judiciais.

\footnotetext{
${ }^{47}$ A Resolução $\mathrm{BCB} \mathrm{n}^{\circ} 3.400$ foi revogada pela Resolução BCB n ${ }^{\circ}$ 4.087, de 24 de maio de 2012, que majorou o montante garantido contra uma instituição financeira de $\mathrm{R} \$ 60.000,00$ para $\mathrm{R} \$ 70.000,00$, valor que se encontra novamente alinhado com o valor máximo de ressarcimento do MRP.

${ }^{48}$ Processo Administrativo CVM n ${ }^{\circ}$ SP 2007/0147, julgado em 17 de janeiro de 2011.
} 
Por fim, o Edital de Audiência Pública n 06/2007, de 28 de junho de 2007, que culminou na edição da Instrução CVM 461, não poderia ter melhor sintetizado as importantes alterações que viriam a ser introduzidas na Instrução CVM 461 quanto ao novo mecanismo de indenização aos investidores, senão vejamos:

\footnotetext{
"As alterações descritas, destacadamente a fixação de um prazo máximo para o pedido de ressarcimento (18 meses) e a limitação do valor máximo devido ( $R \$ 60$ mil), mas também a flexibilização na forma de organização admitida para o mecanismo de indenização de prejuízos, pretenderam torná-lo mais sustentável e apto a atender às necessidades do crescente número de investidores atraídos pelo mercado de capitais. Isso porque a fixação de limites mais claros pode permitir a obtenção dos recursos destinados à sua manutenção de outras formas, além da que até hoje tem sido utilizada, além de viabilizar o ressarcimento de um número maior de pequenos investidores com o mesmo montante total de recursos." (grifos nossos)
}

\subsection{A Instrução CVM 461 e as Hipóteses de Acionamento do MRP}

O artigo 77 da Instrução CVM 461, em clara alusão às hipóteses de acionamento do Fundo de Garantia das Bolsas de Valores previstas no artigo 40 da Resolução BCB 2.690, dispõe de um rol no qual, em caso da incidência comprovada de algum de seus seis tipos, teria o investidor o direito de acionar o MRP, hipóteses que analisaremos adiante com mais detalhes.

Apresentamos abaixo, apenas a título de adiantamento, as hipóteses de acionamento do MRP:

"Art. 77 A entidade administradora de mercado de bolsa deve manter um mecanismo de ressarcimento de prejuízos, com a finalidade exclusiva de assegurar aos investidores o ressarcimento de prejuízos decorrentes da ação ou 
omissão de pessoa autorizada a operar, ou de seus administradores, empregados ou prepostos, em relação à intermediação de negociações realizadas na bolsa ou aos serviços de custódia, especialmente nas seguintes hipóteses:

I - inexecução ou infiel execução de ordens;

II - uso inadequado de numerário e de valores mobiliários ou outros ativos, inclusive em relação a operações de financiamento ou de empréstimo de valores mobiliários;

III - entrega ao investidor de valores mobiliários ou outros ativos ilegítimos ou de circulação restrita;

IV - inautenticidade de endosso em valores mobiliários ou outros ativos, ou ilegitimidade de procuração ou documento necessário à sua transferência;

$V$ - intervenção ou decretação de liquidação extrajudicial pelo Banco Central do Brasil; e

VI - encerramento das atividades."

Preliminarmente, importa salientar que o rol das hipóteses de ressarcimento (enumeradas acima) tratam de controvérsias que, segundo próprio entendimento da $\mathrm{CVM}^{49}$ : (i) podem colocar em dúvida a idoneidade dos intermediários e outras instituições que integrem o sistema de negociação (como, por exemplo, o uso inadequado dos fundos ou ativos dos clientes); (ii) são resultado de erros operacionais da instituição ou do sistema de negociação (como a inexecução ou execução infiel de ordem); ou (iii) resultam da falha do próprio intermediário (como a decretação de liquidação extrajudicial ou o encerramento de atividades).

\footnotetext{
${ }^{49}$ Processo Administrativo CVM n ${ }^{\circ}$ SP 2007/0147, julgado em 17 de janeiro de 2011.
} 
Portanto, há inúmeras outras situações em que um cliente tem um interesse legítimo de ser ressarcido por uma instituição intermediária, tais como certas práticas comerciais danosas ou o descumprimento contratual por parte daquela instituição. Não obstante, tais situações não possuem o condão de colocar em risco a confiabilidade do sistema de mercado de capitais ou são resultado de falhas operacionais, restando, portanto, desamparadas pelo mecanismo de ressarcimento ${ }^{50}$.

Por fim, insta colacionar extrato de voto da Ilma. Diretora da CVM Luciana Dias no âmbito do Processo Administrativo CVM $n^{\circ}$ SP 2007/0147, julgado em 17 de janeiro de 2011, o qual elucida entendimento acerca das hipóteses do artigo 77 da Instrução CVM 461, in verbis:

\begin{abstract}
"Acredito portanto que as hipóteses de ressarcimento do art. 77 da Instrução CVM $n^{\circ} 461$, de 2007, devem ser lidas, sob o prisma de que o mecanismo de ressarcimento é instrumento de lidar com riscos operacionais e de prevenção de abalos à confiabilidade do sistema e não meio de resolver toda e qualquer divergência entre intermediário e cliente. Assim, não é que se deva necessariamente interpretar o art. 77 da Instrução CVM $n^{\circ} 461$, de 2007, de maneira estrita ou formal, ou como uma lista taxativa de hipóteses de ressarcimento, mas a decisão de aplicá-lo ou não deve ser guiada por sua natureza de instrumento de proteção contra riscos operacionais e preservação de confiabilidade do investidor."

(grifamos)
\end{abstract}

a) Inadimplemento contratual e a (não) incidência do MRP

Como dito acima, as hipóteses para acionamento do mecanismo de ressarcimento de prejuízos se resumem às dispostas no artigo $77 \mathrm{da}$ Instrução CVM 461. Não obstante, há uma hipótese que vem sendo utilizada pela BSM em julgamentos de MRPs para legitimar o ressarcimento aos investidores: o inadimplemento contratual com relação à

\footnotetext{
${ }^{50}$ Processo Administrativo CVM n ${ }^{\circ}$ SP 2007/0147, julgado em 17 de janeiro de 2011.
} 
gravação de ordens dadas por clientes.

Nesse sentido, caso haja controvérsia sobre, por exemplo, quem ordenou a execução de determinada ordem de compra e venda (investidor ou agente autônomo), e em não havendo gravação da ordem de compra e venda, a BSM julgaria procedente a reclamação, conforme trecho extraído de voto julgado proferido por aquela entidade autorreguladora em procedimento administrativo semelhante ${ }^{51}$ :

“Há, no entanto, um fato adicional, que foi considerado pela Turma julgadora de primeira instância como crucial para a resolução do conflito: o descumprimento da obrigatoriedade contratual de a Reclamada gravar as ordens" (grifos e negritos nossos)

Como se pode observar, a BSM optou por fundamentar sua decisão com base em uma irregularidade que, em nosso entender, não se amolda às hipóteses de cabimento do mecanismo de ressarcimento de prejuízos. Salientamos que esse, felizmente, é também o entendimento da Comissão de Valores Mobiliários, como demonstrado no âmbito do Processo Administrativo $\mathrm{n}^{\circ} \mathrm{SP} 2007 / 0147^{52}$.

Como será explicado mais adiante, a responsabilidade pelo ressarcimento de prejuízos no âmbito do MRP recai, primariamente, sobre o sujeito passivo indireto (o próprio MRP), mas não sobre o sujeito passivo direto (e.g. a sociedade corretora). Por isso, entendemos que a leitura deveras extensiva do rol de tipos que ensejariam o ressarcimento de

\footnotetext{
${ }^{51}$ Processo de Mecanismos de Ressarcimento de Prejuízos - MRP n ${ }^{\circ}$ 063/2010

${ }^{52}$ Inclusive quando a Ilma. Diretora da CVM, Sra. Luciana Dias, expõe que "o mecanismo de ressarcimento não é remédio para toda e qualquer controvérsia que possa existir entre clientes e intermediários. Ele serve para dirimir situações que possam colocar em cheque a confiabilidade na integridade do sistema de negociação e nas instituições que nele atuam. Outros tipos de disputas devem ser dirimidas pelos mecanismos tradicionais de solução de controvérsias"
} 
prejuízos, tais como o vastíssimo espectro de situações de inadimplemento de obrigações contratuais, poderia criar uma insegurança jurídica aos investidores e, em última análise, à própria confiabilidade do sistema, o que é justamente o oposto do que o mecanismo quer transmitir a todos...

Como demonstrado acima, surge dessa "hipótese" em particular um ponto que entendemos ser de suma importância para o nosso trabalho: poderia a CVM, nesse caso e sem o meio cabível para a sua intervenção (já que, como veremos mais a frente, somente o investidor poderá interpor recurso à CVM, e, nesse caso, não haveria o porquê de existir uma vez que a decisão proferida o é favorável), reformar a decisão da BSM por estender que a leitura de um dispositivo inserido em um ato normativo de sua autoria teria sido claramente abrangente? Quais medidas cabíveis restaria à sociedade corretora nesse caso? Poderia a mesma, excepcionalmente, interpor recurso à CVM, já que o dispositivo alvo da controvérsia é de sua autoria?

No caso em tela, não houve qualquer manifestação pública da CVM sobre a flagrante extrapolação da BSM, deslinde este que estaremos acompanhando até o final da elaboração do presente trabalho monográfico.

Por fim, cumpre salientar que trata-se um precedente com altíssimo potencial danoso ao mercado, que se mantido e observado em situações futuras poderá abrir espaços a oportunistas e aventureiros e se distanciar da histórica função do MRP de assegurar aos investidores uma maneira rápida, efetiva e menos custosa de obter reembolso de seus prejuízos nas hipóteses específicas previstas na regulamentação aplicável.

\section{b) Inexecução ou infiel execução de ordens}

A primeira hipótese (legítima) para o acionamento do mecanismo de 
ressarcimento de prejuízos - a qual, sem sombra de dúvidas, é a mais recorrente em processos do $\mathrm{MRP}^{53} \mathrm{e}$, portanto, daremos mais atenção - é a inexecução ou infiel execução de ordens. Nesse particular, o grande problema da inexecução ou infiel execução de ordens é trazido à tona quando a relação do investidor junto ao mercado não se dá por meio de Home Broker, mas sim pelo agente autônomo ${ }^{54}$.

Por motivos óbvios, a relação interpessoal tem o condão de gerar problemas com maior facilidade do que a relação entre o ser humano e a tecnologia (seja por vezes em virtude da ganância do ser humano, seja simplesmente pela maior propensão ao erro do homem), fato que resta demonstrado, sem maiores delongas, abaixo ${ }^{55}$ :

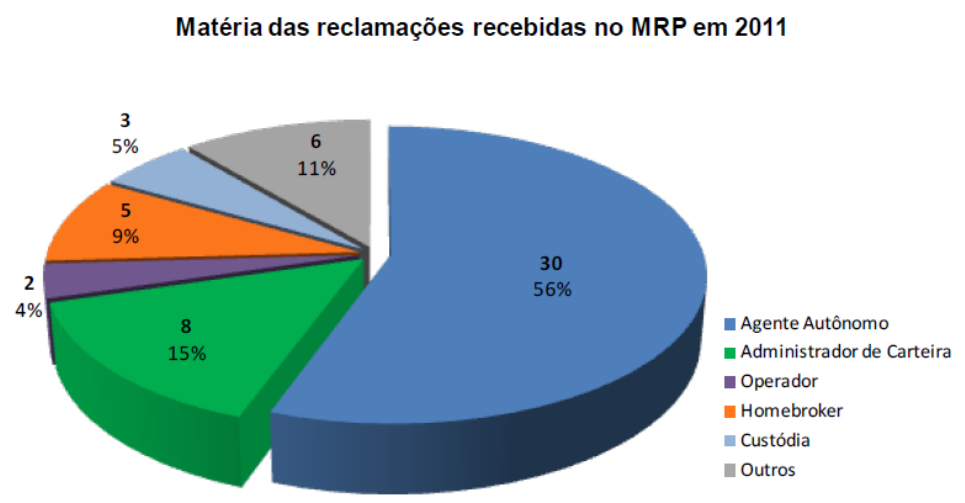

\footnotetext{
${ }^{53}$ Segundo o relatório de 2011 elaborado pelo Ombudsman da BM\&FBOVESPA, os assuntos que lideraram o ranking de reclamações foram as ordens de operações (execução infiel, inexecução ou demora na execução), representando $24 \%$ do total; Home Broker (21\%); dificuldades na transferência de custódia (14\%); e produtos e serviços da BM\&FBOVESPA (7\%). Vale lembrar que, desde 2005, tem sido alvo de críticas os assuntos mencionados nas três primeiras posições do ranking, não necessariamente na mesma ordem. Finalmente, o relatório destacou que, do total das reclamações, $63 \%$ foram direcionadas às corretoras de valores; $18 \%$ à Bolsa; $17 \%$ aos bancos; e $2 \%$ às empresas. Link para o Relatório: http://www.bmfbovespa.com.br/pt-br/abmfbovespa/download/relatorio-anual_2011.pdf.

${ }^{54}$ Segundo o artigo $1^{\circ}$ da Instrução CVM no 497, de 3 de junho de 2011, conforme alterada, agente autônomo de investimento é a pessoa natural, registrada na forma desta Instrução, para realizar, sob a responsabilidade e como preposto de instituição integrante do sistema de distribuição de valores mobiliários, as atividades de: (i) prospecção e captação de clientes; (ii) recepção e registro de ordens e transmissão dessas ordens para os sistemas de negociação ou de registro cabíveis, na forma da regulamentação em vigor; e (iii) prestação de informações sobre os produtos oferecidos e sobre os serviços prestados pela instituição integrante do sistema de distribuição de valores mobiliários pela qual tenha sido contratado.

${ }^{55}$ Fonte: http://www.bovespasupervisaomercado.com.br/InstDownload/Relatorio-de-Atividades2011.pdf
} 
Voltando ao conceito do tipo elencado na alínea "a" do artigo 77 da Instrução CVM 461, e segundo o Vocabulário Jurídico ${ }^{56}$, a inexecução seria a "falta de execução ou o fato de não se cumprir, seja em sua totalidade ou parcialmente, a obrigação a que se estava sujeito, ou o dever ou o encargo imposto". Isto posto, podemos dizer que a inexecução, no âmbito do MRP, seria o descumprimento de uma obrigação quanto à execução de uma ordem de compra e venda dada pelo investidor.

Exemplificativamente, seria a hipótese na qual um investidor solicita a aquisição ou a alienação de determinado ativo em bolsa de valores, quando o mesmo atingir determinado preço previamente acordado (ordem $\operatorname{limitada}^{57}$ ), e tal solicitação não é acatada, pela sociedade corretora.

É o caso, ainda, da solicitação não acatada por sociedade corretora ou seus prepostos - relativa à mera aquisição de determinado ativo por investidor. Com efeito, apresentamos abaixo voto do Ilmo. Diretor da CVM Marcos Barbosa Pinto, no âmbito do Processo Administrativo CVM n ${ }^{\circ}$ 2010/10272, o qual ilustra a hipótese mencionada:

\begin{abstract}
"As mensagens eletrônicas que acompanham a reclamação demonstram que o Reclamante ordenou ao Gerente a realização da operação. Se houvesse alguma razão operacional que impedisse a execução das ordens e elas tivessem sido comunicadas pelo Gerente ao Reclamante nesse momento, não haveria inexecução de ordens que ensejasse ressarcimento pelo MRP.
\end{abstract}

No entanto, o Gerente fez exatamente o oposto: confirmou a execução que na verdade não ocorreu; para que essa mentira não fosse descoberta, meses depois teve que mentir novamente, ao confirmar a execução das ordens de liquidação da operação fictícia. Dificilmente haverá um caso concreto que ilustre com mais

\footnotetext{
${ }^{56}$ SILVA, De Plácido. Vocabulário Jurídico.. 28ª ed. Rio de Janeiro: Editora Forense, 2010. 738 p.

${ }^{57}$ Ordem Limitada é aquela que deverá ser executada somente ao preço igual ou melhor do que o especificado pelo investidor.
} 
(grifamos)

Já a execução infiel diz respeito à transgressão ou violação, por determinada sociedade corretora, do dever de fidelidade ${ }^{58}$ a que estava obrigada. Trazendo especificamente para o campo das operações em bolsa de valores, pode ser vislumbrada quando um investidor solicita à sociedade corretora a qual está vinculado a compra de um ativo em bolsa de valores mas, au contraire, a mesma adquire ativo diverso do previamente acordado.

Outrossim, poderia ser vislumbrada quando o investidor solicita a aquisição de determinado ativo assim que atingir dado preço e a sociedade corretora o adquire a preço mais elevado, causando prejuízo ao investidor.

c) Uso inadequado de numerário e de valores mobiliários ou outros ativos

Já o tipo "uso inadequado de numerário e de valores mobiliários ou outros ativos", previsto no inciso II do artigo 77 da Instrução CVM 461, diz respeito à utilização de valores mobiliários por determinada sociedade corretora sem a prévia autorização do investidor.

Seria este o caso, por exemplo, de corretora que executa uma ordem de venda de determinado ativo sem a prévia anuência do Reclamante, ou, em casos mais raros, o caso do investidor que possuía o direito subjetivo de receber proventos (i.e., dividendos) referentes à determinada companhia e a sociedade corretora, em um ato de liberalidade, não os entrega ao investidor.

\footnotetext{
${ }^{58}$ SILVA, De Plácido. Vocabulário Jurídico.. 28ª ed. Rio de Janeiro: Editora Forense, 2010. 740 p.
} 
Transcrevemos abaixo parecer jurídico da BSM que ilustra essa segunda hipótese, senão vejamos:

“39. Conclui-se que, durante o período da Reclamação, as posições do Reclamante eram custodiadas pela Reclamada, assim, esta tinha como obrigação entregar ao Reclamante todos os proventos decorrentes de suas posições, tais como dividendos e lucros sobre capital próprio. Há, portanto, caracterização da hipótese de ressarcimento prevista no inciso I do artigo 77 da Instrução CVM 461/2007, qual seja, a inexecução da ordem de resgate dos valores constantes da conta corrente do Reclamante, elou a hipótese prevista no inciso II do citado artigo, consistente em uso indevido pela Reclamada de numerário do Reclamante." (grifamos)

d) Entrega ao investidor de valores mobiliários ou outros ativos ilegítimos ou de circulação restrita

Em razão do MRP, atualmente, existir apenas como mecanismo administrado pela BM\&FBOVESPA (até pela sua hegemonia absoluta nesse setor no Brasil), essa hipótese não é mais vislumbrada, uma vez que aquela entidade não admite à negociação valores mobiliários ilegítimos ou de circulação restrita. Além disso, a BM\&FBOVESPA vem aprimorando seus mecanismos de controle interno de forma a vedar qualquer tipo de inscrição de ativos que não possuam respaldo legal em seu ambiente, fato que afasta a incidência dessa hipótese.

e) Inautenticidade de endosso em valores mobiliários ou outros ativos, ou ilegitimidade de procuração ou documento necessário à sua transferência

No que tange à hipótese prevista na alínea "d", cumpre ressaltar que há outrossim, no artigo 11 da Resolução BCB 1.655, de 26 de outubro de 
1989, conforme alterada ${ }^{59}$, previsão expressa no sentido de que a corretora é responsável, para com seus comitentes, pela autenticidade do endosso e a legitimidade das procurações.

Ademais, cumpre salientar que a mencionada hipótese pode ser dividida em dois ilícitos distintos, isto é, (i) a inautenticidade de endosso em valores mobiliários ou outros ativos; ou (ii) a ilegitimidade de procuração ou documento necessário à sua transferência. Como já dito, a BM\&FBOVESPA, durante a última década, automatizou a quase totalidade dos processos de transferência de valores mobiliários em seu ambiente, fato que afasta a praticamente a incidência da "inautenticidade de endosso em valores mobiliários ou outros ativos", até porque o modo pelo qual tais ativos são negociados nos dias atuais não envolve o endosso físico no próprio documento que personifica o valor mobiliário, tal como ocorria antigamente.

Quanto à segunda hipótese, qual seja, a "ilegitimidade de procuração ou documento necessário à sua transferência”, seria o caso de um terceiro que apresenta instrumento falso de procuração à sociedade corretora e esta transfere os ativos de seu cliente ao falso procurador ${ }^{60}$.

\footnotetext{
59 “Art. 11. A sociedade corretora é responsável, nas operações realizadas em bolsas de valores, para com seus comitentes e para com outras sociedades corretoras com as quais tenha operado ou esteja operando: (...) III - pela autenticidade dos endossos em valores mobiliários $e$ legitimidade de procuração ou documentos necessários para a transferência de valores mobiliários."

60 Voto proferido no âmbito do Processo CVM no SP 2004/67 (FG 19/2002 Bovespa) "24. Percebe-se facilmente que não houve o devido cuidado por parte Walpires Corretora, já que a procuração particular utilizada para a transferência das ações sequer tinha firmas reconhecidas, conforme se depreende das cópias anexadas às fls. 15 e 56 (a Walpires Corretora alega que as firma estavam reconhecidas, mas não há prova disto nos autos). 25. Além do mais, a documentação apresentada por Márcia Camilo Flores continha evidentes dados imprecisos, tais como a data de emissão da identidade errada, o número do $R G$ incompleto, o sobrenome do pai faltando a letra "L" e o nome da mãe abreviado. Logo, a Walpires Corretora deveria no mínimo ter tido dúvida razoável quanto à autenticidade do documento, mediante conferência com os dados cadastrais que deveria manter, omitindo-se assim do dever de garantir segurança a seus clientes." (grifamos)
} 


\section{f) Intervenção ou decretação de liquidação extrajudicial pelo Banco Central do Brasil}

Como o próprio nome diz, essa hipótese diz respeito ao caso do investidor que, ao possuir numerário em sua conta corrente junto à determinada sociedade corretora, não ver seu patrimônio completamente dilapidado no caso da intervenção do $\mathrm{BCB}$ ou decretação de liquidação extrajudicial pela mesma entidade.

Colacionamos abaixo voto no âmbito do Processo CVM 2353, julgado em 28 de junho de 1999, que ilustra a situação disposta acima:

"O investidor Augusto Cesar Corrêa Guerreiro Lima era cliente da Vega S/A CCVM, membro da Bolsa de Valores do Rio de Janeiro, quando foi decretada a liquidação extrajudicial daquela instituição. Ocorre que, após a intervenção do Banco Central do Brasil, o liquidante, ao invés de utilizar o saldo credor do cliente para quitar suas operações realizadas antes da liquidação, obrigou o investidor a depositar dinheiro novo.

(...)

A SMI decidiu reformar esta decisão, por entender que estavam presentes os requisitos previstos no art. 41 da Resolução CMN $n^{\circ} 1.656 / 89$ e ter ocorrido a hipótese de ressarcimento prevista na alínea " $e$ " do inciso I.

Diante disso, o Diretor-Relator apresentou voto, com base no artigo 50 da Resolução CMN $n^{\circ} 1.656$, pela condenação dos fundos de garantia da BOVESPA e da BVRJ a ressarcirem o prejuízo integral sofrido pelo reclamante, conforme explicitado em seu voto."

(grifamos) 


\section{g) Encerramento das atividades}

Por último, também caberá ao investidor o ressarcimento dos prejuízos no caso do encerramento das atividades da sociedade corretora. Cumpre mencionar aqui que, como os ativos de cada investidor são custodiados diretamente pela CBLC, o único prejuízo que o investidor poderia experimentar no caso do encerramento de atividades seria dos valores em Reais custodiados na conta corrente da sociedade corretora; nunca os ativos custodiados na CBLC.

\subsection{As Características Primordiais do MRP mantido pela BSM}

Como já explanado nesse trabalho, o MRP tem por finalidade exclusiva assegurar aos investidores (sejam eles pessoas físicas, jurídicas ou universalidade de bens ou direitos), respeitado o limite estabelecido pela $\mathrm{CVM}^{61}$, o ressarcimento de prejuízos no âmbito dos serviços contratados por determinado investidor cuja finalidade seja a de operar nos mercados de bolsa de valores, a prestação de serviços de intermediação de operações com valores mobiliários realizadas nesses mercados ou de serviços de custódia a elas inerentes.

Com efeito, uma característica interessante do MRP é o valor mínimo de seu patrimônio, o qual, segundo Resolução $\mathrm{n}^{\circ} 1^{\circ}$ de 2011 do Conselho de Supervisão da BSM, deve ser de $\mathrm{R} \$ 276.600,00$, ao passo que seu valor máximo estaria limitado a $\mathrm{R} \$ 323.700 .000,00$, até nova deliberação em contrário, sendo que, caso o patrimônio do MRP atinja, a qualquer tempo, montante igual ou inferior ao valor mínimo, acrescido de $30 \%$ da diferença entre o valor máximo e o valor mínimo, a BSM poderá determinar que os Participantes (como definido no Estatuto Social da BSM)

\footnotetext{
${ }^{61}$ Como já dito, esse valor, segundo a Instrução CVM 461, atualmente remonta R \$70.000,00.
} 
realizem contribuições mensais ao MRP, ao passo que caso o patrimônio atinja montante igual ou superior ao valor máximo, determinará a BSM a imediata cessação das contribuições.

Quanto à natureza do MRP, cumpre ressaltar que o mesmo possui características similares às do Fundo de Garantia das Bolsas de Valores (sendo um patrimônio de afetação), constituindo tal mecanismo como uma modalidade de "seguro de responsabilidade civil", isto é, constitui o mesmo como uma técnica de indenização do risco decorrente da atuação das sociedades corretoras no que tange à sua atuação como intermediadora de operações no âmbito das bolsas de valores ${ }^{62}$. Para tanto, o ressarcimento é efetuado pelo próprio patrimônio do MRP, o qual, posteriormente, é recomposto pela sociedade corretora, motivo pelo qual dizemos que o mesmo é o responsável por substituição, ou, nas palavras do Ilmo. Professor Nelson Eizirik, que o mesmo possui uma responsabilidade reflexa da sociedade corretora ${ }^{63}$.

Em outras palavras, o instituto do mecanismo de ressarcimento de prejuízos, não obstante o dano seja provocado por um determinado participante do mercado, possui a obrigação primária de ressarcir, na condição de responsável "por substituição", o investidor. Dizemos, pois, que o indigitado mecanismo, no tocante à relação obrigacional da sociedade corretora e o investidor, seria a figura - tal como no direito tributário - do sujeito passivo indireto, isto é, aquele que muito embora não esteja vinculado diretamente com a relação obrigacional, estaria, por imposição normativa, obrigado a cumpri-la.

\footnotetext{
${ }^{62}$ EIZIRIK, Nelson et al.. Mercado de Capitais Regime Jurídico. $2^{\mathrm{a}}$ ed. Rio de Janeiro: Renovar, 2008. $222 \mathrm{p}$.

${ }^{63}$ EIZIRIK, Nelson et al.. Mercado de Capitais Regime Jurídico. $2^{\mathrm{a}}$ ed. Rio de Janeiro: Renovar, 2008. 222 p.
} 
Não é por outro motivo que colocamos acima o caráter restritivo do rol disposto no artigo 77 da Instrução CVM 461, já que a interpretação extensiva deste dispositivo, como a que relatamos acima por parte da BSM (Capítulo 5.3 A Instrução CVM 461 e as Hipóteses de Acionamento do $M R P)$, iria de encontro à própria necessidade de se manter uma saudável situação financeira e patrimonial desse mecanismo (uma vez estando o mesmo sempre obrigado primeiramente a ressarcir o investidor).

De modo a ilustrar a mecânica por meio da qual o ressarcimento se daria ao investidor, apresentamos abaixo fluxograma que expõe o fluxo do ressarcimento desde o cometimento da infração até a plena satisfação do investidor:

\section{Fluxograma do Ressarcimento do Investidor}

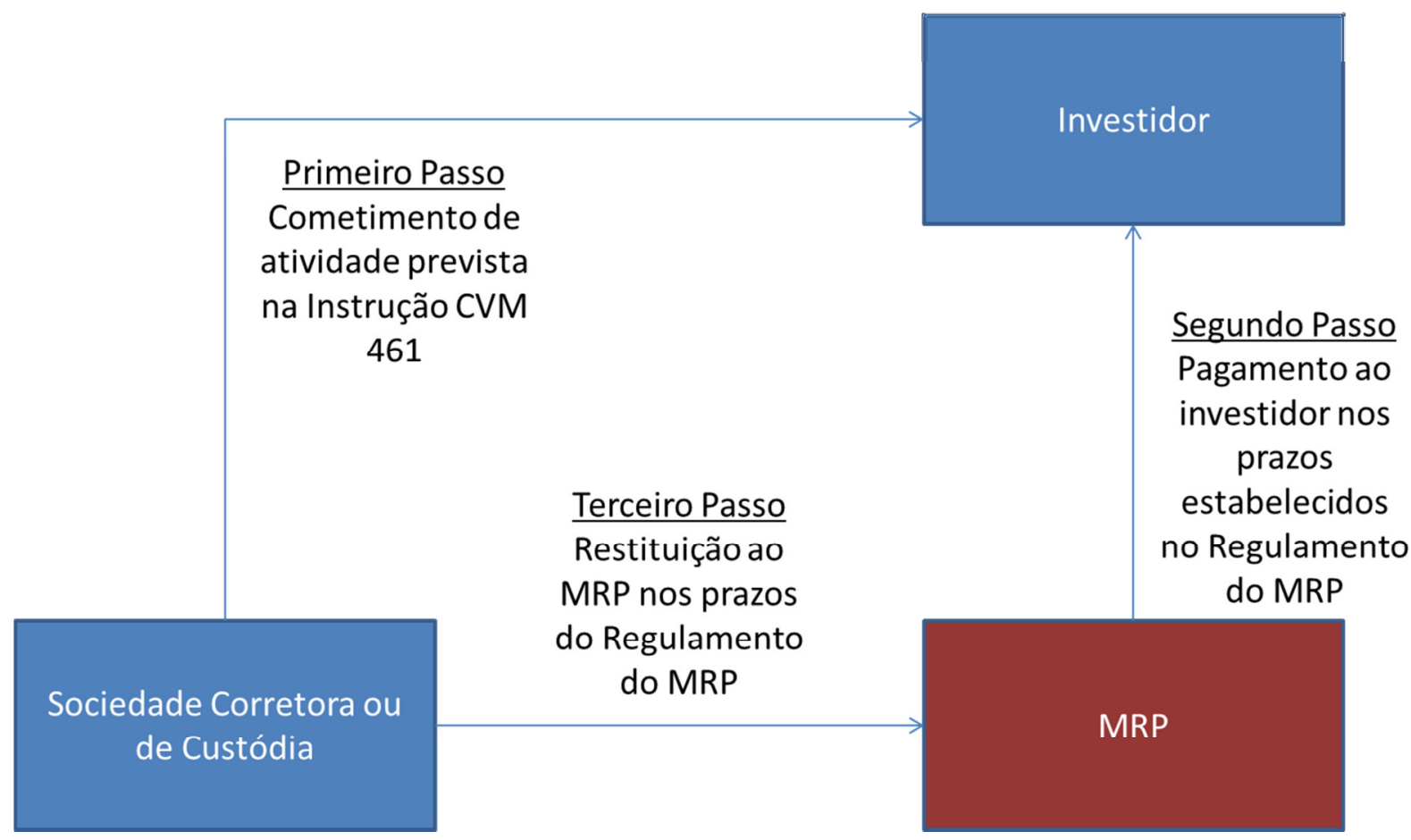

Adentraremos a partir desse momento nas características básicas do MRP constantes de seu regulamento. 
Como dispõe o artigo $2^{\circ}$ do Regulamento do MRP, os investidores poderão pleitear o ressarcimento de prejuízos, por parte do MRP, independentemente de qualquer medida judicial ou extrajudicial, no prazo de 18 meses a contar da data da ocorrência da ação ou omissão que tenha dado origem ao prejuízo, sendo certo que caso seja constatada a existência de ação judicial promovida pelo investidor cujo objeto seja o mesmo do MRP, a BSM deverá informar o juízo sobre a reclamação impetrada, a instauração do respectivo procedimento administrativo e o seu andamento.

Ademais, e segundo o artigo $4^{\circ}$ do $\mathrm{MRP}$, a reclamação será formulada por escrito ao MRP, devidamente fundamentada com os documentos inerentes ao prejuízo reclamado, contendo: (i) firma reconhecida de seu signatário; (ii) qualificação do Reclamante; (iii) indicação do nome da Reclamada que teria causado o Prejuízo; (iv) descrição da ação ou omissão da Reclamada que teria causado o Prejuízo; (v) indicação do valor do Prejuízo; e (vi) a forma de ressarcimento pretendida, que não poderá ser alterada: em dinheiro ou em valores mobiliários.

Uma vez recebida na BSM, a Reclamação será autuada, instaurandose o respectivo processo administrativo de MRP, o qual receberá um número e será conduzido sob sigilo.

Caso a reclamação não atenda aos requisitos acima dispostos, considerando o prazo de cinco dias no qual o investidor poderá aditá-la, pode o Diretor de Autorregulação determinar o arquivamento da peça, cabendo recurso ao Pleno do Conselho de Supervisão, no prazo de 10 dias, contados da data em que o investidor for cientificado dessa decisão.

Outro ponto de suma importância no MRP é o fato do investidor poder optar pelo ressarcimento em duas espécies distintas, quais sejam, em 
(i) pecúnia; ou (ii) valores mobiliários (vide reflexões sobre essas modalidades no próximo capítulo).

Caso o investidor opte pelo ressarcimento em dinheiro, o mesmo será atualizado pelo Índice de Preços ao Consumidor - IPCA, ou índice que o substituir, acrescido de juros de $6 \%$ ao ano, devidos a partir da data que ocorreu o prejuízo. Para fins do cálculo desse valor a ser ressarcido em pecúnia, será considerada a cotação média dos valores mobiliários alvo dos prejuízos nos mercados de bolsa administrados pela BM\&FBOVESPA, observada na data do prejuízo.

Por outro lado, caso o investidor tenha optado pelo ressarcimento de valores mobiliários, deverão os mesmos, segundo artigo 30, parágrafo primeiro, do Regulamento do MRP, serem do mesmo emissor, tipo, espécie e classe, acrescidos de quaisquer direitos distribuídos em relação aos mesmos, no período entre a ocorrência do prejuízo e o seu ressarcimento, inclusive aqueles que dependam de manifestação de vontade.

Quanto aos ritos do MRP, o artigo $9^{\circ}$ do Regulamento do MRP dispõe que o processo de MRP será instruído segundo um dos seguintes ritos processuais, os quais resumiremos suas características a seguir:

(i) Rito Ordinário: aplicável a processos de MRP em que o valor total de ressarcimento pleiteado seja superior a $\mathrm{R} \$ 20.000,00$;

(ii) Rito Sumário: aplicável a processos de MRP em que o valor total de ressarcimento pleiteado seja de até $\mathrm{R} \$ 20.000,00$, inclusive; e

(iii) Rito Sumaríssimo: aplicável a processos de MRP que, 
independentemente do valor pleiteado, por suas características, possam ser julgados com base em entendimento majoritário do Conselho de Supervisão da BSM, consubstanciado em Súmula ${ }^{64}$.

Rito Ordinário: Instaurado o processo do MRP, deverá a reclamada apresentar defesa, no prazo de dez dias contados do recebimento da notificação, a respeito de todos os fatos narrados pelo reclamante na reclamação, devendo ainda apresentar todas as informações, esclarecimentos ou documentos que fundamentem suas alegações ou porventura solicitados pela BSM.

No Rito Ordinário, a BSM possui a prerrogativa de, a seu exclusivo critério, realizar as diligências que considerar necessárias à instrução do processo de MRP, inclusive solicitar informações adicionais à Reclamada, que deverá atendê-las na forma e no prazo estabelecidos pela BSM.

Concluída a fase de instrução, será elaborado parecer jurídico conclusivo sobre o pedido de ressarcimento, o qual deverá conter: (a) relatório do processo de MRP; (b) análise da tempestividade da Reclamação e da legitimidade das partes; (c) seus fundamentos e a indicação das normas infringidas; e (d) em caso de procedência, parcial ou total, indicação do valor e das condições de pagamento do ressarcimento ao reclamante, incluindo a indicação do patrimônio do MRP que responderá pelo ressarcimento.

Após elaboração do referido parecer, os autos serão encaminhados ao Diretor de Autorregulação, que apresentará seu entendimento em relação

\footnotetext{
${ }^{64}$ As súmulas serão emitidas pelo Conselho de Supervisão da BSM, em reunião extraordinária convocada exclusivamente para essa finalidade, e consistirão no entendimento majoritário daquele órgão em relação a determinada matéria, obtido após reiteradas decisões em processos do MRP que contenham características semelhantes.
} 
ao processo de MRP e encaminhará os autos ao Conselho de Supervisão para julgamento. Para o julgamento do processo do MRP, será designada turma composta por três membros do Conselho de Supervisão.

Caberá recurso ao pleno do Conselho de Supervisão, pela reclamada, da decisão de turma que julgar procedente ou parcialmente procedente o pedido do reclamante, sendo certo que tal decisão será a decisão final em esfera administrativa.

Por outro lado, caberá recurso à CVM, pelo reclamante, da decisão da turma do Conselho de Supervisão que julgar improcedente ou parcialmente improcedente o seu pedido, bem como na hipótese de decisão do pleno do Conselho de Supervisão que reformar, total ou parcialmente, a decisão da turma do conselho. Como se percebe, não cabe recurso ao reclamante ao pleno do Conselho de Supervisão em caso de decisão desfavorável, mas tão somente à CVM.

Rito Sumário: No processo de Rito Sumário, as mesmas disposições constantes do processo de Rito Ordinário quanto a apresentação de defesa, a elaboração de diligências, e a elaboração de um parecer jurídico são aplicáveis.

Quanto ao julgamento, o processo do MRP será julgado pelo Diretor de Autorregulação, cabendo recurso, por parte da reclamada, ao pleno do Conselho de Supervisão caso seja julgado procedente ou parcialmente procedente o pedido do reclamante. No caso do reclamante, caberá recurso ao CVM, da decisão do Diretor de Autorregulação que julgar improcedente ou parcialmente improcedente o processo do MRP, bem como da decisão da turma ou do pleno do Conselho de Supervisão que reformar a decisão do Diretor de Autorregulação, conforme o caso, para improcedente ou parcialmente improcedente. 
Rito Sumaríssimo: Caso reste configurada a aplicabilidade da Súmula do Conselho de Supervisão, o processo de MRP conduzido sob rito sumaríssimo será submetido à apreciação do Diretor de Autorregulação para julgamento. Quanto às hipóteses de recurso, aplicam-se as mesmas do rito sumário descritas acima.

\subsection{Algumas Reflexões sobre as peculiaridades do MRP}

Diante de todo o exposto, apresentaremos abaixo algumas problemáticas acerca de determinadas disposições do Regulamento do MRP, bem como eventuais sugestões de forma a mitigar potenciais efeitos lesivos ao investidor ou à sociedade corretora / custodiante decorrentes da aplicação objetiva de seus dispositivos.

\section{a) Prescrição de 18 meses}

Nesse particular, indagamo-nos (uma vez ser silente o Regulamento do MRP quanto a isso): Nos casos onde diversas operações são realizadas em um lapso temporal determinado, e, supostamente, sem o consentimento do investidor (o que configurar-se-ia a execução infiel de ordem), em qual momento exato poderíamos inferir restar configurada a data da ocorrência da ação ou omissão que tenha dado origem ao prejuízo (e, pois, o marco inicial da prescrição de 18 meses a que se refere o Regulamento do MRP)?

Seria no momento da primeira operação realizada pelo preposto sem o conhecimento do investidor, sendo cada operação tratada isoladamente e cada uma tendo um prazo específico de prescrição? Ou seria toda a ilicitude, considerada como um todo, um ato contínuo (tal como o crime continuado), e, portanto, a última operação realizada sem o consentimento do investidor? Inclinamo-nos pela primeira opção, onde cada operação deveria ser tratada isoladamente, muito embora o histórico de julgados da 
BSM não favoreça nem para essa, tampouco para aquela hipótese.

Não obstante, apresentamos abaixo julgado da BSM que, acertadamente - a nosso ver -, compartilha da mesma opinião à qual nos $\operatorname{afiliamos}^{65}$ :

“15. Portanto, para a análise da tempestividade, há que se dividir o período reclamado em duas fases, a saber:

- Intempestividade da Reclamação quanto às operações realizadas no período de 22/1/2008 a 10/9/2008, eis que transcorrido o prazo de 18 meses previsto no Artigo 80 da ICVM $n^{\circ}$ 461/2007, considerando-se como termo inicial a data da ocorrência das referidas operações;

- Tempestividade da Reclamação quanto às operações realizadas no período de 11/9/2008 a 28/9/2009 (data da última operação realizada em nome do Reclamante), eis que observado o prazo de 18 meses"

Como se pode observar, o referido processo é segregado, para fins de ressarcimento, em dois períodos, tendo um já prescrito, e, outro, ainda dotado de legitimidade para ser, caso julgado procedente pelo Conselho de Supervisão, eventualmente ressarcido. Tal entendimento, muito embora não expressamente exposto no Regulamento do MRP, seria o mais equitativo a nosso ver.

\section{b) Forma de Ressarcimento de Prejuízos}

Como já dito mais especificamente acima, o ressarcimento de prejuízos pelo MRP dar-se-á, pela escolha do investidor, em dinheiro ou valores mobiliários.

65 Parecer da Gerência Jurídica no âmbito do julgamento do Processo de Mecanismo de Ressarcimento de Prejuízo n ${ }^{\circ}$ 23/2010, o qual, muito embora não vincule a decisão do Conselho de Supervisão, nos traz diversas diretrizes sobre as tendências julgadoras daquela entidade autorreguladora. 
Nesse particular, causa-nos estranheza, desde já, o fato de ser devido a um investidor, caso tenha direito ao ressarcimento de prejuízos, além do valor principal, a atualização pelo IPCA e o acréscimo de juros de $6 \%$ ao ano. Cumpre ressaltar que, caso o investidor tivesse investido na quase totalidade dos meios de investimento disponíveis ao público, jamais faria jus a qualquer remuneração dessa monta (ainda mais que o antigo Regulamento do MRP instituía a atualização pelo IPCA e o acréscimo de juros de $\underline{\mathbf{1 2 \%}}$ ao ano), restando indagarmo-nos, mais uma vez, se o instituto do MRP seria uma forma de ressarcimento justa ao investidor ou, talvez, uma forma de punição à parte sucumbente.

Urge analisar, ainda, a modalidade de ressarcimento de prejuízos que envolve a entrega dos valores mobiliários ao investidor por meio de um caso hipotético, o qual instou sua criação apenas para elucidar, de forma clara, situações análogas ao intuito equitativo do MRP:

Determinado Investidor "A" possuía em sua carteira junto a determinada Corretora "B" 1.000 ações ABCD4 e 1.000 ações EFGH3. Em $1^{\circ}$ de janeiro de 2010, tais ações teriam sido alienadas, segundo o investidor, sem a sua autorização, pelo preço de $\mathbf{R}$ \$1,00 cada ação ABCD4 e R\$2,00 cada ação EFGH3. Ao apurar os fatos, a BSM, em $1^{\circ}$ de janeiro de 2011, optou pela procedência do pedido do Investidor "A" junto ao MRP por entender que, de fato, a Corretora "B" teria cometido a infração relativa à execução infiel de ordem, prevista no artigo 77, inciso (i), da Instrução CVM 461. Com efeito, o MRP, em $1^{\circ}$ de janeiro de 2011, repôs a quantidade de valores mobiliários que o Investidor "A" na data do ocorrido, tendo sido tal mecanismo ressarcido pela sociedade corretora no tempo regulamentar. 
Primeiramente, cumpre ressaltar a ausência de procedimentos específicos para o ressarcimento em valores mobiliários do Regulamento do MRP, fato que colocaria um fim em situações paradoxais decorrentes do caso acima. Adiantamos, desde já, que a mera entrega da quantidade de valores mobiliários fruto da alienação indevida tal como no caso acima poderia criar situações extremamente absurdas, senão vejamos:

$\left(1^{\circ}\right)$ hipótese:

Em $1^{\circ}$ de janeiro de 2011, data em que o MRP efetuou a recompra dos valores mobiliários a mercado para entrega ao Investidor "A", verificou-se que as ações ABCD4 estariam cotadas a um valor unitário de $\mathbf{R} \$ 0,01$ e, as ações EFGH3, a um valor unitário de $\mathbf{R} \$ 0,02$. Diante dessa situação, estaria o investidor se deparando com uma perda substancial de seu patrimônio, uma vez que, na data da ocorrência, possuía um investimento no montante de $\mathrm{R} \$ 3.000,00$, ao passo que na data em que teve seu direito concedido, receberia em valores mobiliários o montante ínfimo de $\mathrm{R} \$ 30,00$ (1.000 ações ABCD4 vezes R\$0,01 e 1.000 ações EFGH3 vezes $\mathrm{R} \$ 0,02)$.

$\left(2^{\circ}\right)$ hipótese:

Em $1^{\circ}$ de janeiro de 2011, data em que o MRP efetuou a recompra dos valores mobiliários a mercado para entrega ao Investidor "A", verificou-se que as ações ABCD4 estariam cotadas em valor unitário a R\$3.000 e, as ações EFGH3, a R\$3.000. Diante dessa situação, estaria o investidor se deparando com um ganho substancial de seu patrimônio, uma vez que, na data da ocorrência, possuía um investimento no montante de $\mathrm{R} \$ 3.000,00$, ao passo que na data em que teve seu direito concedido, receberia em valores mobiliários o montante absurdo de $\mathrm{R} \$ 60.000,00$ (1.000 ações ABCD4 vezes $\mathrm{R} \$ 3.000,00$ e 1.000 ações EFGH3 vezes 
$\mathrm{R} \$ 3.000,00)$.

De forma a demonstrar que quaisquer das situações acima podem se concretizar, colacionamos a seguir voto no âmbito do Processo do Mecanismo de Ressarcimento $n^{\circ}$ 11/2010, julgado em 23 de março de 2012, que, após ter julgado procedente o pedido do investidor, impôs ao MRP (e indiretamente à sociedade corretora) a restituição de "4.600 ações JBSS3 $e$ 900 ações PETR4, observados os limites previstos no regulamento do Mecanismo de Ressarcimento de Prejuízo". Como se pôde extrair da análise do referido processo, mais precisamente de seu relato, o reclamante teria solicitado justamente o ressarcimento de "ações que eu tinha após 31/10/2008, ou seja, 4.600 ações da JBSS3 e 900 ações da PETR4, visto que as mesmas foram vendidas sem a minha autorização, pois conforme mencionei acima as operações realizadas após esta data não eram de meu conhecimento”. Infere-se, portanto, que a quantidade de valores mobiliários pleiteada pelo Reclamante foi a mesma recebida ao fim do processo ${ }^{66}$.

Por isso, e tendo em vista as hipóteses demonstradas acima, entendemos que a BSM deveria adotar, para que não haja no futuro situações semelhantes, entendimento no sentido de que a quantidade de valores mobiliários a serem eventualmente restituídos em processos no âmbito do MRP deveria observar a cotação média dos valores mobiliários objeto de ressarcimento desde a data de ocorrência do prejuízo até a data do ressarcimento, sob pena de transgressão ao Regulamento da BSM e, a depender das circunstâncias de cada caso, de (i) enriquecimento sem causa do Reclamante; ou (ii) reposição parcial dos prejuízos sofridos pelo $\underline{\text { Reclamante, na medida em que o cálculo das cotações atuais e ao tempo da }}$ operação tida como irregular serve justamente para balizar a equidade da

\footnotetext{
66 Importante destacar que as cotações individuais das ações JBSS3 e PETR4 no caso em tela sofreram diversos rodopios e não mantêm qualquer identidade entre a data de alienação indevida e a data do julgamento do processo, fato que afasta de plano a hipótese de entrega na quantidade e valor exato dos valores mobiliários referidos.
} 
recomposição eventualmente devida pelo MRP.

Uma terceira hipótese ao caso do Investidor "A" acima seria a de, no momento de recompra a mercado dos valores mobiliários, o MRP se deparasse com uma situação na qual a empresa emissora dos valores mobiliários tenha cancelado seu registro com o consequente fechamento de capital, ou, ainda, seus valores mobiliários tenham sido convertidos de uma classe ou espécie para outra. Teria o MRP, caso a emissora tenha fechado o capital, meios para adquirir esses valores mobiliários? Indo mais além: estaria o MRP, no silêncio de seu Regulamento quanto a possibilidade de inexistência de recompra dos valores mobiliários, obrigada a restituir o Investidor "B", já que a causa de pedir do Investidor "B" restaria inexistente?

Talvez uma saída para tal situação seria a conversão compulsória, de ofício pela BSM, do modo do ressarcimento (já que o Reclamante, segundo o Regulamento do MRP, não poderia alterar a pretensão inicial de seu pleito caso tenha optado ou por dinheiro ou por valores mobiliários), isto é, da hipótese de restituição de valores mobiliários para a hipótese de restituição pelo valor correspondente em pecúnia. Não há, todavia, qualquer previsão no Regulamento do MRP nesse sentido. 


\section{Conclusão}

Como se pôde depreender da leitura do presente trabalho monográfico, nos preocupamos em apresentar, em seus pontos críticos, mais indagações do que afirmações propriamente ditas, de modo a aguçar a reflexão do leitor e o próprio debate, em foro intimo, dos problemas nesse campo do mercado de capitais.

Assim, procuramos demonstrar, com a sobriedade que o tema requer, o histórico da regulação no mercado de capitais no Brasil e o papel da CVM no âmbito de suas funções reguladoras, analisando as funções normativa e fiscalizadora que a mesma exerce.

Já no que tange à autorregulação, colocamos breve histórico das bolsas de valores no Brasil e, nesse particular, apresentamos o conceito de autorregulação no País e suas principais características. Ainda, tentamos deixar exposta, pelo sabor do debate, a grande questão que permeia o tema, isto é, a autorregulação das bolsas de valores vis-à-vis a regulação da CVM no Brasil e a reflexão sobre o limite da sujeição daquelas à esta.

Não ficou cristalino para nós a relação limítrofe de atuação da CVM e das bolsas de valores, tampouco a sujeição dessas em contraposição àquela. Colocamos aqui, mais uma vez, uma das indagações primordiais do presente trabalho: poderia a CVM intervir em decisão da bolsa de valores que vá de encontro a determinado entendimento consolidado por aquela entidade reguladora? Ainda, tal independência regulamentar poderia ser nefasta em algum momento?

Entendemos, em uma análise preliminar, que não, muito embora esse ponto careça de uma análise mais profunda que, dado ao (in)conveniente 
limite tacitamente imposto aos trabalhos dessa natureza, não pudemos aqui demonstrar.

Mais a frente, apresentamos uma visão analítica da BSM, entidade que exerce o papel autorregulador da BM\&FBOVESPA, apresentando suas principais atribuições, sua administração e o papel do seu Conselho de Supervisão.

Finalmente, iniciamos o escrutínio das formas de proteção ao investidor, colocando o histórico do fundo de garantia das bolsas de valores até o atual MRP, expondo a conjuntura de sua criação e os anseios da Instrução CVM 461.

Em seguida, estudamos - uma a uma - as hipóteses de acionamento do MRP, bem como discutimos a questão relativa ao inadimplemento contratual como "nova hipótese" do MRP. Como abordado no corpo do trabalho acima, essa questão ainda não nos parece pacífica, uma vez que a CVM entende que o inadimplemento contratual, embora enseje legítimo direito de indenização pelo reclamante, não estaria enquadrado nas hipóteses do MRP; por outro lado, a BSM entende que tal inadimplemento contratual, ao fim e ao cabo, colocaria a sociedade corretora em uma situação na qual o não cumprimento com seu dever de gravação de conversas telefônicas deveria ensejar o ressarcimento do investidor, basicamente por uma questão de "in dubio pro misero" (na dúvida de quem enviou as ordens, protege-se o elo mais fraco, no caso o investidor).

Quanto à questão levantada, não há dúvidas de que ao investidor principalmente o investidor pequeno - deve haver sempre o direito da ampla tutela, visto que o mesmo notadamente constitui elo mais fraco na 
relação com a sociedade corretora e, em suma, com o mercado em geral.

Não obstante, e como já decidido pela CVM - decisão essa à qual nos filiamos -, somos favoráveis ao entendimento de que o investidor, naqueles casos apontados de inadimplemento contratual, teria sem sombra de dúvida o interesse legítimo para pleitear a restauração de seu direito devassado; não obstante, tal pleito não deveria encontrar guarida no MRP, mas sim no foro competente para julgar lides dessa natureza, i.e., a justiça comum!!

Ainda no que toca ao MRP, e com o estrito intuito de aguçar o leitor quanto a algumas reflexões que faremos abaixo, gostaríamos de apresentar abaixo tabela contendo o resultado das reclamações apresentadas por investidores junto à BSM em 2011 ${ }^{67}$ :

MRP - Finalização das reclamações e processos

\begin{tabular}{lcc} 
& Qtde & $\%$ \\
\hline Reclamações arquivadas & 22 & $23 \%$ \\
Processos encerrados por desistência ou acordo entre as partes & 8 & $8 \%$ \\
Processos julgados improcedentes & 49 & $52 \%$ \\
Processos julgados procedentes (total ou parcialmente) & 16 & $17 \%$ \\
\hline Total & 95 & $100 \%$ \\
\hline
\end{tabular}

Após a análise da tabela acima, concluindo que a ampla maioria das reclamações foi julgada improcedente, entendemos serem necessárias as seguintes reflexões, quais sejam: Estaria a BSM optando pelo julgamento em favor das entidades intermediadoras do mercado, uma vez que as mesmas garantem parcela significativa dos resultados financeiros de sua entidade mantenedora (i.e., a BM\&FBOVESPA)? Indo mais além, estariam

67 Fonte: http://www.bovespasupervisaomercado.com.br/InstDownload/Relatorio-de-Atividades2011.pdf. 
os investidores apresentando reclamações apenas na qualidade de "aventureiros", esperando serem ressarcidos de prejuízos decorrentes única e exclusivamente de sua responsabilidade? Infelizmente, não temos como saber - tampouco deduzir - as respostas para tais indagações, deixando a resposta para cada uma delas a critério pessoal do leitor...

Ao final do trabalho, apresentamos as características primordiais do MRP, principalmente quanto ao desenrolo processual das lides ali apresentadas e, por fim, reflexões sobre possíveis fragilidades do Regulamento do MRP e as consequências que tais pontos podem levar.

Concluímos, portanto, que o Regulamento do MRP poderia ser um pouco mais claro no que tange à redação de alguns de seus dispositivos, principalmente àquela relativa à prescrição de 18 meses e ao ressarcimento em pecúnia ou valores mobiliários, de modo a não haver dúvidas quanto a sua aplicação, tanto com relação aos investidores, quanto aos potenciais réus nesses processos.

Com efeito, é notável que a criação desse mecanismo fez prover ao mercado de capitais, especialmente em tempos de crise econômica, uma situação jurídica mais sólida e confiável, fato que distingue o Brasil de muitas jurisdições que, muito embora possuam uma economia mais sólida, carecem de um dispositivo de suma importância, qual seja, um mecanismo que favoreça e, em última análise, proteja o investidor contra (i) arbitrariedades de agentes intermediários; e (ii) situações nas quais os mesmos se vejam reféns de infortúnios gerados pelo próprio risco do negócio (como o encerramento de atividades e liquidações extrajudiciais).

Não obstante, e concluindo o presente trabalho, entendemos que muito há que se fazer - e, por que não dizer, percorrer -, notadamente no campo da reflexão, com relação (i) à distinção entre meros 
inadimplementos contratuais e as hipóteses do MRP; (ii) à determinados dispositivos do Regulamento do MRP; e (iii) ao relacionamento, muitas vezes oposto, da entidade reguladora e autorreguladora de mercado de capitais no Brasil.

Diante de todo o exposto, não traduziria com maior virtude as melhoras - e por que não dizer, os percalços? - que temos que experimentar para que possamos, de fato, cimentar os pilares de uma economia saudável, baseada em uma autorregulação do mercado de capitais sóbria e um mecanismo de proteção aos investidores efetivamente protecionista, senão as palavras de Winston Churchill ${ }^{68}$ :

"Success is the ability to go from one failure to another with no loss of enthusiasm"

${ }^{68}$ O sucesso é a habilidade de ir de fracasso em fracasso sem a perda do entusiasmo. 


\section{BIBLIOGRAFIA}

\section{Doutrina}

FILHO, Gustavo Alberto Villela. As Sociedades Corretoras e o Mercado de Valores Mobiliários. Rio de Janeiro: Lumen Juris, 2003. MENDONÇA, José Xavier Carvalho de. Tratado de Direito Comercial Brasileiro. $3^{\circ}$ ed., vol. VI, parte II Rio de Janeiro, 1939, n. 1585 .

EIZIRIK, Nelson et al.. Mercado de Capitais Regime Jurídico. $2^{\mathrm{a}}$ ed. Rio de Janeiro: Renovar, 2008.

LAMEIRA, Valdir de Jesus. Mercado de Capitais. $1^{\mathrm{a}}$ ed. Rio de Janeiro: Forense Universitária, 2001.

MELLO, Celso Antonio Bandeira de. Curso de Direito Administrativo. $17^{\mathrm{a}}$ ed. São Paulo: Malheiros Editores, 2004.

DI PIETRO, Maria Sylvia Zanella. Direito Administrativo. São Paulo: Atlas, 2001.

RESENDE, André Lara. Estabilização e reforma: 1964-1967. 1990. In Abreu, M. (org.), A Ordem Do Progresso, Rio de Janeiro. Campus.

FILHO, Luiz Chrysostomo de Oliveira. Mercado de capitais $e$ crescimento econômico - lições internacionais, desafios brasileiros. Rio de Janeiro: Contra Capa, 2005.

YAZBEK, Otávio. Regulação do Mercado Financeiro e de Capitais. $2^{\circ}$ ed. Elsevier, 2009.

SILVA, De Plácido. Vocabulário Jurídico.. $28^{\mathrm{a}}$ ed. Rio de Janeiro: Editora Forense, 2010. 


\section{Jurisprudência}

\section{(II).a CVM}

Parecer/CVM/PJU/N ${ }^{\circ}$ 001/2003. Henrique de Rezende Vergara, 06.02.2003.

Processo Administrativo CVM n ${ }^{\circ}$ RJ 2004/4558-4559-4569-4583, 21.09.2004.

Processo Administrativo Sancionador CVM n 32/98, 06.05.2004.

Processo Administrativo CVM SP nº 2011/0253, 16.11.2011.

Processo Administrativo CVM n ${ }^{\circ}$ SP 2007/0147, 17.01.2011.

Processo CVM no SP 2004/67 (FG 19/2002 Bovespa), 18.10.2005.

\section{(II). b BSM}

Processo de Mecanismos de Ressarcimento de Prejuízos - MRP n ${ }^{\circ}$ 063/2010, 23.03.2012.

Processo de Mecanismo de Ressarcimento de Prejuízos - MRP n $23 / 2010$. 